UNIVERSIDADE DE BRASÍLIA

INSTITUTO DE GEOCIÊNCIAS

PÓS- GRADUAÇÃO EM GEOCIÊNCIAS APLICADAS

\title{
MAPEAMENTO GEOMORFOLÓGICO APLICADO AO ESTUDO DO USO E COBERTURA DA TERRA NO PLANALTO CENTRAL
}

BRUNA CARDOSO MENDES

Orientador: Prof. Dr. Éder de Souza Martins

BRASÍLIA - DF

2015 


\title{
MAPEAMENTO GEOMORFOLÓGICO APLICADO AO ESTUDO DO USO E COBERTURA DA TERRA NO PLANALTO CENTRAL
}

\author{
BRUNA CARDOSO MENDES
}

Orientador: Prof. Dr. Éder de Souza Martins

Dissertação de Mestrado apresentada à Banca Examinadora do Instituto de Geociências Aplicadas (Geoprocessamento e Análise Ambiental) da Universidade de Brasília, como exigência para obtenção do título de mestre em Geociências.

BRASÍLIA - DF

2015 


\section{UNIVERSIDADE DE BRASÍLIA}

Instituto de Geociências

\section{MAPEAMENTO GEOMORFOLÓGICO APLICADO AO ESTUDO DO USO E COBERTURA DA TERRA NO PLANALTO CENTRAL}

BRUNA CARDOSO MENDES

BANCA EXAMINADORA

Orientador

Avaliador Interno

Avaliador Externo

Brasília, AGOSTO de 2015 


\section{AGRADECIMENTOS}

Muitas das realizações em nossas vidas não dependem exclusivamente de nosso conhecimento ou da nossa vontade, elas se concretizam pelo incentivo, pela paciência, pela curiosidade e pelo companheirismo que encontramos ao longo do caminho.

Agradeço ao Éder pela paciência, pelo incentivo e pela presença. me o foco.

Agradeço ao Antônio Felipe por sua disposição, presteza e habilidade para mostrar-

Agradeço ao Elton, que me inspirou e motivou a dar continuidade no aprendizado e a pesquisa. Que me serve de exemplo de dedicação e persistência.

Agradeço aos colegas de pós, que frequentemente me ajudaram e contribuíram para o meu desenvolvimento.

Agradeço aos professores que impactaram a ótica pela qual eu compreendia o mundo. Em especial agradeço ao Edson Sano, Henrique Llacer e ao Gustavo Baptista, que me instruíram de maneira harmoniosa e convidativa, tornando o conhecimento transmitido instantaneamente assimilado. 


\section{RESUMO}

MENDES, B.C. Mapeamento geomorfológico aplicado ao estudo de uso e ocupação da terra no Planalto Central. 2015. 77 f. Dissertação (Mestrado em Geociências Aplicadas) - Instituto de Geociências, Universidade de Brasília, Brasília, 2015.

A paisagem, enquanto resultado das interações endógenas e exógenas, apresenta características distintas, representando seu contexto geomorfológico e os eventos que a modelaram ao longo do tempo. Tais características individualizam a paisagem em unidades, seja pelo relevo, clima, cobertura vegetal, solos, pelo arranjo estrutural e litologia ou exclusivamente por um desses elementos. Usando o mosaico com dados da missão topográfica SRTM que recobrem a Ecorregião do Planalto Central foi realizada 1) a delimitação automática das bacias hidrográficas do Rio das Almas (GO) e Rio Maranhão (GO/DF); e 2) foram extraídas as variáveis morfométricas de declividade, curvatura mínima e máxima e aspecto. As bacias hidrográficas ocupam juntas uma área de $34.641,95 \mathrm{~km}^{2}$, correspondem a cerca de $10 \%$ da área do Estado do Goiás e possuem litologia representativa da Ecorregião do Planalto Central. As variáveis morfométricas foram alternadas nos canais RGB para selecionar o arranjo de melhor contraste e como resultado obteve-se a altimetria, declividade e curvatura mínima, respectivamente nos canais RGB. A partir da composição colorida os padrões de cor, textura e forma foram vetorizados em tela, resultando em oito unidades geomorfológicas: 1) Chapadas e Remanescentes (3,17\%); 2) Frentes de recuo erosivo (12,39\%); 3)Rampas de colúvio I (4,53\%); 4) Planalto retocado (31,57\%); 5) Depressão interplanáltica (18,69\%); 6) Serras (14,35\%); 7) Rampas de colúvio II (11,99\%); e 8) Depressão Dissecada (3,28\%). Foi realizado um estudo em nível de bacias e em nível de unidade geomorfológica com base no uso e cobertura da terra a fim de relacionar a distribuição do uso e cobertura da terra às características topográficas de cada unidade. As bacias possuem áreas com uso e cobertura distintos, sendo predominante a agricultura e a pastagem com 32,44\% e 40,29\%, respectivamente, na bacia do Rio das Almas (GO) e o cerrado com 48,55\% na bacia do Rio Maranhão (GO/DF). A unidade geomorfológica de Chapadas e Remanescentes possui potencial de uso para agricultura e cerrado; as Rampas de colúvio I e II, planalto retocado e depressão dissecada possuem potencial de uso para agricultura, pastagem e cerrado; e as Frentes de recuo erosivo e as serras possuem potencial de uso para floresta e cerrado.

Palavras-chave: mapeamento geomorfológico, assinatura de uso. 


\section{ABSTRACT}

MENDES, B.C. Geomorphological mapping applied to the study of land use and occupation in the Central Planalto. 2015. $77 \mathrm{f}$. Dissertação (Mestrado em Geociências Aplicadas) - Instituto de Geociências, Universidade de Brasília, Brasília, 2015.

The landscape as a result of endogenous and exogenous interactions, has distinct characteristics, representing its geomorphological context and the events that shaped it over time. Such features individualize the landscape units, or topography, climate, vegetation cover, soil, the structural arrangement and lithology or exclusively by one of these elements. Using the mosaic with SRTM topographic mission of data that cover the Ecoregion of the Central Plateau was conducted 1) automatic delineation of the watershed of the Rio das Almas (GO) and Maranhão River (GO / DF); and 2) were extracted morphometric variables of slope, minimum and maximum curvature and aspect. Watersheds together occupy an area of 34,641.95 square kilometers, corresponding to about $10 \%$ of the state of Goiás area and have representative lithology of the Central Plateau Ecoregion. The morphometric variables were alternating in the RGB channels to select the best contrast arrangement, and as a result obtained the altitude, slope and minimum curvature respectively in the RGB channels. From the colorful make the color patterns, texture and shape were vectorized on screen, resulting in eight geomorphological units: 1) Plateus and Remmants (3.17\%); 2) fronts of erosive retreat (12.39\%); 3) Colluvial Ramps I (4.53\%); 4) Retouched Plateu (31.57\%); 5) Interplanaltic Depression (18.69\%); 6) Ridges (14.35\%); 7) Colluvial Ramps II (11.99\%); and 8) Dissected Depression (3.28\%). A study at the level of basins and level of geomorphological unit based on the use and land cover in order to relate the distribution of land use and land cover to the topographical features of each unit was conducted. The basins have areas with different use and cover, being predominantly agriculture and pasture with $32.44 \%$ and $40.29 \%$, respectively, in the Almas River basin (GO) and the savannah with $48.55 \%$ in the basin Rio Maranhão (GO / DF). The geomorphological unit Chapadas Remnants and has potential use for agriculture and savanna; the Colluvial RampsI and II, retouched and dissected plateau depression have potential use for agriculture, pasture and cerrado; and the erosive retreat fronts and the mountains have potential use for forest and savanna.

Key words: geomorphological mapping, geocover signature. 


\section{Capítulo 1}

Figura 1. Táxons de classificação da paisagem em relação ao relevo. Fonte: Adaptação de IBGE, 2009.

Figura 2. Localização das antenas do ônibus espacial Endeavour. Fonte: USGS ImagesSRTM.

16

Figura 3. Reamostragem dos dados do SRTM pela NASA e pela USGS numa janela de 3 por

3 usado para geração de modelos com resolução de 3 arsec. Fonte: Adaptado de Steiner, 2007.

\section{Capítulo 2}

Figura 4. Composição colorida para digitalização manual das unidades geomorfológicas.

Fonte: Sena-Souza, 2013.

Figura 5. Classificação geomorfológica segundo IBGE (2009); B) Resultado da digitalização das unidades geomorfológicas usando composição colorida das variáveis morfométricas; C) Unidades geomorfológicas identificadas na Bacia do Rio São Bartolomeu (Sena-Souza, 2013); D) Validação em campo.

Figura 6.Localização das Bacias do Rio das Almas e do Rio Maranhão na Faixa Brasília.

Fonte: Adaptação de Campos et al., 2013.

Figura 7. Em sequência visualizamos o modelo digital de elevação, a direção de fluxo e a hidrografia.

Figura 8. Comparação dos limites das bacias hidrográficas da codificação de Otto e as bacias delimitadas automaticamente a partir do MDE.

Figura 9. Trajeto de validação das unidades geomorfológicas das bacias Rio das Almas (GO)

e Rio Maranhão(GO/DF).

Figura 10. Bacias Hidrográficas.

Figura 11. Frequência da altimetria e da declividade nas bacias do Rio das Almas e Rio

Maranhão.

Figura 12. Distribuição do Uso e Cobertura da terra nas Bacias do Rio das Almas (GO) e Rio

Maranhão (GO/DF).

Figura 13 Planos de informação da composição colorida com as variáveis Altimetria (m),

Declividade (\%) e Curvatura Mínima, nos canais RGB, respectivamente. 50

Figura 14. Unidades Geomorfológicas das bacias do Rio das Almas e Rio Maranhão no

Goiás.

Figura 15. Gráfico de área percentual das unidades geomorfológicas das bacias do Rio das Almas (GO) e Rio Maranhão (GO/DF).

Figura 16. Unidades geomorfológicas e suas frequências altimétricas e de declividade. __ 53

Figura 17. Distribuição do Uso e Cobertura da terra nas bacias do Rio das Almas (GO) e Rio

Maranhão (GO/DF).

Figura 18. Litologia das Bacias Hidrográficas do Rio das Almas (GO) e Rio Maranhão (GO/DF).

Figura 19. Ocorrência dos solos nas bacias do Rio das Almas e Rio Maranhão. Fonte: SIEG :

MacroZEE - Meio físico, 2014.

Figura 20. Frequência da altimetria e da declividade no uso e cobertura da terra. __ 56

Figura 21 Assinatura de Uso e Cobertura da terra na bacia do Rio das Almas (GO).__ 58

Figura 22. Uso e Cobertura da terra nas unidades geomorfológicas da bacia do Rio Maranhão

(GO/DF).

Figura 23. Perfil topográfico das bacias do Rio das Almas e Rio Maranhão e a distribuição das unidades geomorfológicas. Transecto Rio das Almas: FR - Frentes de Recuo Erosivo; PR - Planalto Retocado; SE - Serras; DI - Depressão Interplanáltica; RCII - Rampas de Colúvio 
II; DD - Depressão Dissecada. Transecto Rio Maranhão: CH - Chapadas e Remanescentes; FR - Frentes de Recuo Erosivo; RCI - Rampas de Colúvio I; PR - Planalto Retocado; SE Serras; DI - Depressão Interplanáltica; RCII - Rampas de Colúvio II; DD - Depressão

Dissecada.

Figura 24. Área de Cerrado inseridas nas Unidades de Conservação da Natureza na Bacia do Rio Maranhão (GO/DF). 


\section{LISTA DE TABELAS}

\section{Capítulo 2}

Tabela 1. Chave de identificação das unidades Geomorfológicas. Fonte: Adaptação de SenaSouza (2013).

Tabela 2. Características das unidades geomorfológicas das bacias do Rio das Almas (GO) e Rio Maranhão (GO/DF).

Tabela 3. Tabela das áreas percentual do uso e cobertura da terra nas unidades geomorfológicas. Fonte: Uso e Cobertura da terra, MacroZEE, 2014. 56

Tabela 4. Distribuição dos solos nas unidades geomorfológicas. Área percentual. 57

Tabela 5. Áreas das unidades geomorfológicas, seu potencial de uso e as áreas da unidade que ainda podem ser ocupadas. 
RESUMO__II

ABSTRACT__ III

LISTA DE FIGURA__ IV

LISTA DE TABELAS __ VI

CAPÍTULO 1 - APRESENTAÇÃO GERAL __ 8

1. INTRODUÇÃO _ 9

1.1. JUSTIFICATIVA__ 10

1.2. OBJETIVOS 10

1.2.1. Específicos 10

2. MAPEAMENTO GEOMORFOLÓGICO___ 10

2.1. UNIDADES GEOMORFOLÓGICAS _ 11

2.2. SISTEMA RADAR SRTM E MAPEAMENTO GEOMORFOLÓGICO_

3. GEOMOFOLOGIA E USO E COBERTURA DA TERRA__ 17

3.1. AS TÉCNICAS DO MAPEAMENTO GEOMORFOLOGICO__ 19

3.1.1. Metodologia do IBGE - RADAMBRASIL _ 20

3.1.2. Mapeamento Geomorfológico do Goiás em $1991 \_21$

3.1.3. Mapeamento Geomorfológico do Goiás em $2005 \_22$

3.1.4. Metodologia Aplicada — 23

REFERÊNCIAS BIBLIOGRÁFICAS _ _ 28

CAPÍTULO 2: UNIDADES GEOMOROFOLÓGICAS DAS BACIAS DO RIO DAS ALMAS (GO) E RIO MARANHÃO (GO/DF) E O ESTUDO DO USO E COBERTURA DA TERRA — 37

RESUMO__ 38

ABSTRACT 39

1. INTRODUÇÃO

2. MATERIAL E MÉTODOS _

2.1 ÁREA DE ESTUDO _ 41

2.2. AQUISIÇÃO DAS IMAGENS DO SENSOR SRTM _

2.3. DELIMITAÇão AUTOMÁTICA DE BACIAS HIDROGRÁFICAS __ 43

2.4. VARIÁ veis MORFométricas E COMPOSIÇão COLORIDA

2.5. DELIMITAÇão das UNIDAdes GeOMORFológicas E ANÁlISE DE USO E

COBERTURA DA TERRA

2.6. VALIDAÇÃO DO MAPEAMENTO GEOMORFOLÓGICO___

3. RESULTADOS E DISCUSSÃO _

4. CONCLUSÃO_ 62

REFERÊNCIAS BIBLIOGRÁFICAS __ 64 
CAPÍTULO 1 - APRESENTAÇÃO GERAL 


\section{INTRODUÇÃO}

Autores como Bertrand (1972), Zonneveld (1972,1979), Turner e Gardner (1991) conceituam a paisagem como resultante da interação de fatores físicos, biológicos e antrópicos; orgânicos e inorgânicos, variando a ênfase de autor para autor, mas convergem na ideia de ser uma porção de espaço, parte da superfície, formas de relevo de uma região que possui características distintas em função da escala de observação.

A dinâmica da paisagem está em função do tempo e espaço, de maneira que os fatores formadores da paisagem - rocha, clima, relevo, solos e organismos - apresentam processos dinâmicos próprios, mesmo na inter-relação. $\mathrm{O}$ relevo ocupa posição central na escala de ciclos de formação, transformação e reformação da paisagem, (Martins et al, 2004a) permitindo o estudo da espacialização de fenômenos por meio das unidades geomorfológicas, que individualizam padrões topográficos no ambiente.

As unidades geomorfológicas refletem a combinação entre potencial ecológico (que envolve clima, a hidrologia e a geomorfologia), a exploração biológica (fauna, flora e solo) e ação antrópica (representada pelas manifestações socioeconômicas e culturais da sociedade) (Vale, 2012). São unidades que obedecem a uma hierarquia de classificação por meio da individualização de unidades que representam as interações e intrarelações entre rocha, clima, solo, vegetação e organismos ao longo do tempo (Martins et al, 2004b), e que possibilitam o estabelecimento de relações com a vegetação, com os solos, com a geologia e com o uso e a ocupação da terra.

O aperfeiçoamento dos sensores orbitais projetados para o mapeamento topográfico e as técnicas de Processamento Digital de Imagens integradas ao Sistema de Informações Geográficas são úteis ao estudo da descrição e análise geomorfológica permitindo que se amplie a compreensão da dinâmica do relevo e dos fatores atrelados a ele (Borges et al., 2007) por meio da integração de dados referentes a superfície terrestre e da sistematização de padrões espaciais.

Para a representação da superfície são usados modelos digitais em formato de grade regular ou irregular obtidas pela interpolação de amostras pontuais e/ou linear, com dados altimétricos (Barros, 2006). Neste contexto, os sistemas radar tem uma aplicabilidade na representação da superfície peculiar, pois possuem uma correlação direta entre seu retroespalhamento e a rugosidade do terreno (IBGE, 2009), além de permitir a derivação de variáveis morfométricas (Passo et al., 2004). Estas podem ser avaliadas numa composição colorida ressaltando visualmente as características do relevo para o mapeamento 
geomorfológico, conforme feito por Lima et al. (2009), Castro et al. (2010), Passo et al. (2010) e Sena-Souza et al. (2013).

A missão topográfica de radar - SRTM oferece dados gratuitos de $80 \%$ da superfície terrestre com resolução de 30 e 90 m (resolução degradada) (USGS, 2014). Seu modelo digital de elevação fornece dados altimétricos e permite a extração de variáveis morfométricas que auxiliam na caracterização geomorfológica. A resolução de 90 m é considerada adequada para a análise de escalas menores que 1:100.000 até 1:50.000 (Fernandes da Silva e Candeias; 2006; Grohmann et al., 2007), servindo ao estudo geomorfológico em escalas regionais.

Portanto, o estudo geomorfológico é fundamental para a compreensão da organização da paisagem, dividindo a paisagem em níveis de análise que permitem a relação das unidades com atributos do meio físico e biótico ou socioeconômico.

\subsection{Justificativa}

As bacias do Rio das Almas e Rio Maranhão do Goiás ocupam juntas uma área de $34.641,95 \mathrm{~km}^{2}$, correspondendo a cerca de $10 \%$ da área do Estado do Goiás, estão inseridas na Faixa Brasília e possuem litologia representativa da Ecorregião do Planalto Central (Arruda et al., 2006).

A necessidade de planejamento territorial com vistas a eficiência de uso do solo e conservação do meio ambiente requer maiores informações cartográficas que auxiliem na compreensão da dinâmica da paisagem e sua auto-organização, logo, a área de estudo, em função de suas características, torna-se uma área de referência para estudo da distribuição do uso e cobertura da terra em relação às unidades geomorfológicas.

\subsection{Objetivos}

O objetivo deste trabalho foi mapear as unidades geomorfológicas das bacias do Rio das Almas (GO) e Rio Maranhão (GO/DF) e avaliar o potencial uso das unidades.

\subsubsection{Específicos}

Estabelecer relação entre as características do relevo das unidades geomorfológicas e a distribuição do uso e cobertura da terra nas bacias do Rio das Almas (GO) e Rio Maranhão (GO/DF).

\section{MAPEAMENTO GEOMORFOLÓGICO}


Segundo Argento (2011) o conhecimento espacial sempre despertou interesse, primeiramente para saber onde no espaço ocorriam os fenômenos, segundo, em como esses fenômenos se distribuíam, e em terceiro, porque ocorriam daquela forma. Assim a geomorfologia se apropria do avanço tecnológico para viabilizar interfaces com o sensoriamento remoto, com a cartografia computadorizada e com os sistemas de informações geográficas. Por ser relativamente recente, o mapeamento geomorfológico no contexto operacional ainda não possui um padrão de escalas ou bases taxonômicas. Por isso, cada mapeamento deve fornecer informações coerentemente representadas de conteúdo prático e operacional para tomada de decisão no planejamento territorial, seja ele rural, urbano ou regional.

A caracterização geomorfológica se dá pela análise dos elementos ou feições (usada em estudos semidetalhados), ou a partir da análise das formas e dos padrões (mais usada em escalas médias e pequenas, em estudos integrados ou análise da paisagem) (Florenzano, 2008).

\subsection{UNIDADES GEOMORFOLÓGICAS}

A geomorfologia estuda aspectos morfológicos da topografia e da dinâmica responsável pela esculturação das paisagens topográficas visando compreender o modelado terrestre (Cristofoletti, 1994). Por isto, este conhecimento torna-se um instrumento para a compreensão dos suportes físicos do relevo, no conhecimento da gênese das formas e nos processos morfogenéticos que controlam a evolução da paisagem.

Autores como Bertrand (1971) e Sotchava (1977) propuseram a classificação da paisagem em unidades que a individualizasse permitindo o estudo dos aspectos que distinguem as unidades entre si. Bertrand (1971) enfatiza que a delimitação das unidades da paisagem é feita pelo pesquisador e serve como uma forma de aproximação da realidade geográfica, pois a paisagem é situada no tempo e no espaço, numa abordagem da escala, e por isso os fenômenos que ocorrem apresentam um momento de manifestação inicial e um momento de extinção, graças a isso é possível a delimitação sistemática das unidades da paisagem de forma hierarquizada (Pissanati e Archela, 2009).

Objetivando espacializar e classificar as feições geomorfológicas que constituem a paisagem é realizado o mapeamento geomorfológico seguindo uma hierarquia de classificação (Robaina et al., 2010; SANTOS, Justina e Ferreira, 2012). Tal hierarquia divide a paisagem em níveis de estudo, compartimentos, em que o primeiro reflete as formas 
regionais, na qual a escala permite a identificação dos efeitos da estrutura no relevo (classificação morfoestrutural), o segundo nível reflete a influência climática ao longo do tempo geológico (classificação morfoescultural), e o terceiro nível, que é resultado das integrações das variáveis do relevo e do substrato rochoso num primeiro momento e dos materiais dos processos superficiais num segundo momento (Robaina et al., 2010; Santos, Justina e Ferreira, 2012).

O conhecimento dos compartimentos geomorfológicos subsidia na análise do meio físico, no sentido que pode ser usado como base para análise de uso e ocupação da terra e da cobertura vegetal, além do refinamento das informações geomorfológicas obtidas auxiliarem na identificação de potencialidades e fragilidades da paisagem (Trentin, Robaina e Sccoti, 2013), ou seja, as informações dos compartimentos geomorfológicos, unidades geomorfológicas, são relacionadas aos outros fatores na paisagem, tais como as características sedimentológicas (Gastão e Maia, 2010; Polizel e Rossetti, 2014), com a morfodinâmica fluvial (Cavalcante e Cunha, 2012; Merino, Assine e Pupim, 2013), e com a geologia (Silva et al., 2007; Ibanez, Miranda e Riccomini, 2014).

As unidades geomorfológicas permitem a avaliação dos aspectos que individualizam a paisagem e o entendimento das formas de evolução do relevo servindo como subsídio para apropriação racional do mesmo e a compreensão dos processos pretéritos e atuais que o modelam (Casseti, 2005; Borges, 2008;). A identificação das unidades geomorfológicas permite a interpretação de fatores que interferem na estabilidade da paisagem contribuindo no entendimento do contexto geomorfológico (Robaina et al, 2010), isso é possível porque as unidades são identificadas por eu padrão topográfico e sua classificação permite inferir sua estabilidade quanto aos processos e as formas que possui; observar o grau de recorrência, que por sua vez reflete a diversidade ambiental; e a fragilidade ou vulnerabilidade relacionada as interferências antrópicas (Rodrigues, 2010).

Porquanto, assumimos que as unidades geomorfológicas podem ser definidas como uma categoria para compreensão da paisagem, que refletem a relações entre rocha, clima, relevo, solo e organismo ao longo tempo (Martins et al., 2004) evidenciando características distintas e padrões expressivos dos conjuntos de modelados, que fornecem indicações diretas da seleção de áreas com adequadas peculiaridades de ponderáveis a grandes, médios e pequenos projetos ligados ao planejamento regional (Donzeli et al. 2003).

A identificação dos padrões das unidades geomorfológicas está em função da escala de observação. As unidades geomorfológicas são unidades representativas da paisagem que 
permitem a observação de padrões de interação entre as variáveis do meio físico, em suas fragilidades e potencialidades do ambiente, contudo, a escala é determinante para conceituação das unidades, e autores como Sotchava (1977) e Bertrand (1971) em suas propostas iniciais de classificação das unidades fundamentaram-se em conhecimentos locais de paisagens que lhes era familiar. Neste sentido, Ross (1992) aborda o mapeamento geomorfológico das unidades em níveis escalares e hierárquicos, que abrange desde unidades morfoestruturais ( $1^{\circ}$ taxon) até modelados ( $4^{\circ}$ táxon) (Oliveira e Chaves, 2010) (figura 1). A base da caracterização dos táxons definidos pelo IBGE (209) é a cartografia geomorfológica de Ross (1992), contudo a taxonomia do primeiro vai até o $4^{\circ}$ táxon, enquanto o segundo vai até o $6^{\circ}$ táxon.

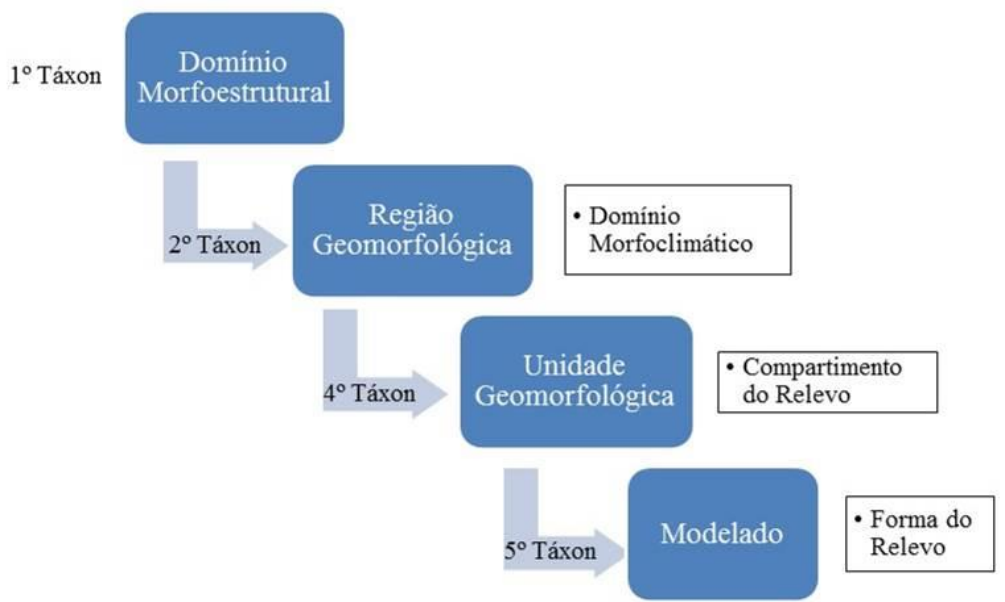

Figura 1. Táxons de classificação da paisagem em relação ao relevo. Fonte: Adaptação de IBGE, 2009.

A definição das unidades geomorfológicas tem como princípio básico o ordenamento dos fatos geomorfológicos de acordo com uma classificação temporal e espacial, na qual os modelados são discernidos como unidades básicas e seus grupamentos hierarquicamente relacionados (IBGE, 2009). Para tanto, são considerados parâmetros fatores causais, de natureza estrutural, litológica, pedológica, climática e morfodinâmica, responsáveis pela evolução das formas de relevo e pela composição da paisagem no decorrer do tempo geológico (IBGE, 2009).

Os dominíos morfoestruturais ocorrem em escala regional e organizam os fatos geomorfológicos por constituição geológica, marcado pela natureza das rochas e pela tectônica que atua sobre elas. Esses fatores são representados por conjuntos de relevo com características próprias, que apesar de ter feições diversas mantém as relações com a estrutura geológica da qual se formaram (IBGE, 2009). Segundo Ross (1992) este táxon define um padrão de formas grandes do relevo, em que a morfoestrutura é o suporte para as 
morfoesculturas. Não devemos confundir a morfoescultura com a morfoclimática, pois o primeiro é resultado da ação climática sobre a estrutura litológica, enquanto o segundo referese aos processos morfogenético definido por tipo climático.

Regiões Geomorfológicas representam compartimentos inseridos nos conjuntos litomorfoestruturais que, sob a ação de fatores climáticos pretéritos e atuais, possuem características genéticas comuns, agrupando feições semelhantes, associadas as formações superficiais e as fitofisionomias (IBGE, 2009). As unidades que caracterizam as regiões geomorfológicas mesmo distintas - depressões e/ou planaltos - podem ocupar o mesmo domínio morfoclimático atual sem que suas características morfogenéticas sejam iguais (Ross, 1992).

As unidades geomorfológicas são definidas como um arranjo de formas altimetricamente e fisionomicamente semelhantes em seus diversos tipos de modelados. Cada unidade geomorfológica evidencia seus processos originários, formações superficiais e tipos de modelados diferenciados dos demais. O comportamento da drenagem, seus padrões e anomalias são referências para revelar relações entre os ambientes climáticos atais ou passados e as condicionantes litológicas ou tectônicas (IBGE, 2009). Neste táxon os processos morfoclimáticos são facilmente notados, e as distinções de aparência entre si são resultado da rugosidade topográfica e índice de dissecação do relevo (Ross, 1992). Esta é a unidade de interesse a este estudo, e seus compartimentos podem ser identificados como planícies, depressões, tabuleiros, chapadas, patamares, planaltos e serras (IBGE, 2009).

\subsection{SISTEMA RADAR SRTM E MAPEAMENTO GEOMORFOLÓGICO}

As geotecnologias contribuem por inovar na eficiência em estudos que envolvem a geomorfologia, pois possibilitam maior precisão nas análises, fornecem novos meios de investigação para situações até então difíceis, quando não impossíveis de serem testadas, e incrementam a capacidade de processamento de dados (IBGE, 2009).

Ao mapeamento das unidades geomorfológicas o sistema radar é singular, pois existe uma correlação direta entre a característica de seu retroespalhamento e a rugosidade do terreno, em que quanto mais brilhante ou maior o retorno do sinal do radar mais rugosa é a superfície avaliada (IBGE, 2009), além de permitir a derivação de variáveis morfométricas (Passo et al., 2004).

Neste quesito, os dados SRTM vem como subsídio para oferecer informações mais qualificadas da compartimentação do relevo, da sua estrutura superficial e fisiologia da 
paisagem, tanto pela disponibilidade gratuita destes dados quanto pela qualidade dos mesmos. Ressaltando que a qualidade dos dados obtidos pelos satélites / sensores está diretamente relacionada ao seu processamento, e a representação da topografia através de modelos digitais está relacionada a praticidade e eficiência na satisfação dos objetivos das pesquisas, que muitas vezes não eram sanadas pelas bases oficiais, seja em decorrência da escala usada, que não atendia as necessidades da pesquisa, ou pela ausência do conhecimento da metodologia usada na geração daquele dado, ou até mesmo na ausência de informação desejada no dado disponível (Vrieling, 2006; Salgado et.al, 2012)

Há várias denominações para designação de modelos digitais que representem a superfície terrestre, a topografia ou o uso. Comumente são usados Modelo Digital de Elevação - MDE, Modelo Digital de Terreno - MDT, Modelo Digital de Superfície - MDS, Modelo Numérico de Elevação - MNE ou suas siglas em inglês DEM, DTM, DSM, respectivamente. Os modelos de elevação representam a superfície e o que nela estiver acrescido e podem ser gerados por digitalização de dados topográficos coletados em campo, a partir de dados de elevação de sensoriamento remoto aéreo e orbital (Iorio, 2012); enquanto os modelos de terreno são representações mais próximas da superfície real do terreno, uma forma de representar numericamente uma característica ou fenômeno espacial ambiental (Paranhos Filho et al., 2008).

Os programas de geoprocessamento utilizam representações digitais em formato de grades regulares e irregulares a partir de interpolação de informações que podem ser pontuais e/ou lineares (BARROS, 2006). Os modelos digitais gerados através dos dados de satélites / sensores permitem a compreensão da dinâmica da paisagem e dos processos de formação da paisagem contribuindo nas diversas áreas de espacialização de fenômenos naturais e antrópicos.

A missão topográfica de radar - SRTM imageou $80 \%$ da superfície terrestre entre os paralelos $60^{\circ} \mathrm{N}$ e $56^{\circ} \mathrm{S}$, e seus dados permitem a representação da superfície em modelos tridimensionais (Grohmann, et.al, 2008). O ônibus espacial possuía duas antenas de abertura sintética, a banda - C $(5.6 \mathrm{~cm})$ e a banda - X $(3.1 \mathrm{~cm})$, também conhecidas como C-Radar e X-Radar, respectivamente (FARR et al., 2007; Sobrinho et al., 2010). A banda - C foi desenvolvida pela NASA, enquanto a banda - X pela Agência Espacial Alemã - DLR. O tamanho do comprimento de onda torna as ondas do SRTM sensíveis a rugosidade da superfície (Florenzano, 2008). Outro fator importante é a variação na constante dielétrica dos 
alvos que influencia na intensidade do retorno do sinal emitido pelo radar (FARR et al., 2007) (figura 2).

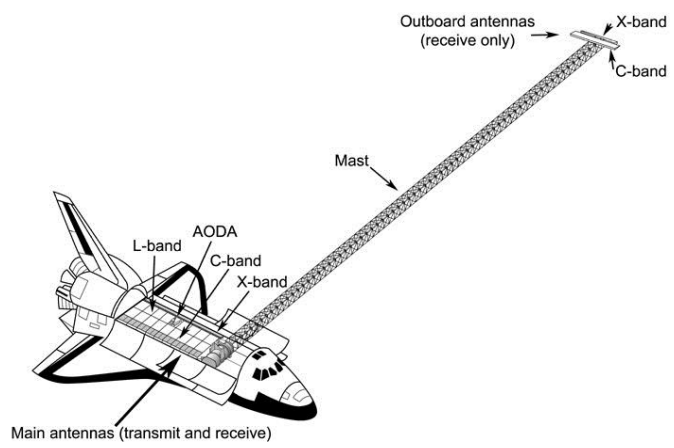

Figura 2. Localização das antenas do ônibus espacial Endeavour. Fonte: USGS ImagesSRTM.

Todas as cenas da superfície imageada são obtidas numa resolução de 30 metros, contudo, estes dados no momento do tratamento para disponibilização ao usuário são reamostrados (Miceli et.al, 2011). Há dois distribuidores destes produtos, a NASA e a USGS, e cada um possui um método de reamostragem. A NASA reamostra os dados numa janela de 3 por 3, em que o valor do pixel central é mantido no produto final, enquanto a USGS aplica um método de reamostragem também numa janela 3 por 3 , mas executa uma média aritmética dos valores dos pixels, e dessa forma o valor do pixel do produto final é uma média dos valores reais dos pixels numa janela de 3 por 3 (figura 3 ).

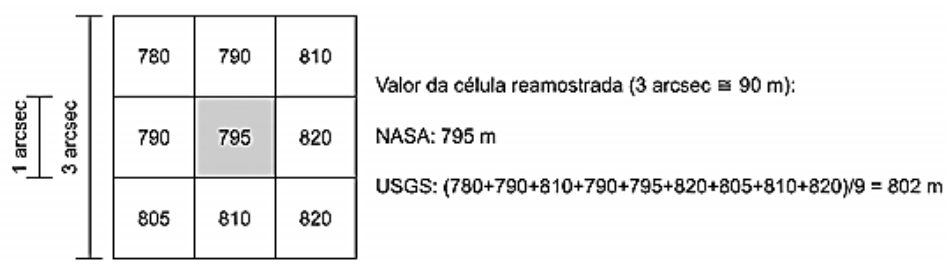

Figura 3. Reamostragem dos dados do SRTM pela NASA e pela USGS numa janela de 3 por 3 usado para geração de modelos com resolução de 3 arsec. Fonte: Adaptado de Steiner, 2007.

A resolução de $90 \mathrm{~m}$ dos dados SRTM é considerada adequada para análise em escalas de 1:250.000, 1: 100.000 até 1:50.000 (Fernandes da Silva e Candeias, 2006). A precisão vertical global está em torno de $\pm 16 \mathrm{~m}$ e a horizontal em torno de $\pm 20 \mathrm{~m}$ (Rabus et al., 2003) para os produtos finais. Os produtos da América do Sul possuem precisão vertical de $6,2 \mathrm{~m}$ e a horizontal de $19 \mathrm{~m}$ (Rodriguez et al., 2006)

Apesar das limitações de representações de superfícies abaixo do dossel, e o mascaramento de profundidade de canais (Farr et al.,2007; Grohmann, et al, 2008, Valeriano et al., 2006b), ou mesmo a presença de vazios de dados (Farr e Kobrick, 2000; Farr et al., 2007) existe confiabilidade na aplicação prática dos modelos oriundos deste sensor (Yang et 
al., 2011; Sharma e Tiwari, 2014), de maneira que a qualidade do resultado do uso dos dados do SRTM estão relacionados a especificidade das regiões estudadas e sua finalidade de aplicação (Li et al.,2013; Nikolakopoulos et al., 2006; Shafique et al., 2011; Thomas et al., 2014; Sharma et al., 2010ab, Shortridge e Messina, 2011).

Além dos dados altimétricos fornecidos pelo MDE do SRTM é possível extrair variáveis morfométricas para caracterização da paisagem reduzindo a demanda de trabalho manual e subjetividade das atividades, dando respaldo ao estabelecimento das relações entre as variáveis topográficas e atributos da paisagem, como solos, clima e vegetação (Valeriano, 2008). As variáveis morfométricas são derivadas do dado altimétrico, e a cada derivação é acrescentada mais atributos numéricos acumulando mais informações para análise do relevo e oferecendo mais elementos para interpretação visual (Valeriano, 2008), importante ressaltar que as derivações possuem erros acumulados do dado original.

As geotecnologias oferecem uma nova forma de se descrever, reconhecer, analisar e

integrar informações. É a apropriação do conhecimento, aplicação, analise de possibilidades e perspectivas para estudos de espaço, território, região, paisagem e lugar (Costa e Rocha, 2010). A oportunidade de avaliar as observações do mundo empírico com o mundo abstrato teórico (Harvey, 1969).

\section{GEOMOFOLOGIA E USO E COBERTURA DA TERRA}

Sempre é possível encontrar relações entre a natureza e as atividades do homem (IBGE. 2013), principalmente assumindo que as condições ambientais são limitantes a capacidade de progredir do homem (Costa e Rocha, 2010) e que o homem transforma o meio em que se insere (La Blache, 1954). O meio físico é a base da sobrevivência do homem (Suertegaray e Nunes, 2001).

Para que haja uma ocupação ordenada do território é preciso considerar os fatores limitantes e as potencialidades dos recursos naturais no meio físico, biótico e socioeconômico, mas não há uma base de dados em escalas cartográficas com respostas em nível taxonômico, e por isso o planejamento atual não os considera. Neste sentido o mapeamento geomorfológico realiza o ordenamento de fenômenos gerando informações que além de valor intrínseco auxiliem no planejamento de ocupação territorial por meio de cenários ambientais (Cruz, 1998; Silva, 2011; Argento, 2011). O estudo dos cenários ambientais possibilita a ação de manejo e conservação das paisagens com vistas redução de desequilíbrios ambientais. 
A geomorfologia é o resultado das interações morfométricas, pedológicas, geológicas, florísticas, hidrológicas e antrópicas, com eventos, processos e entidades associadas, seu estudo pode ser de cunho aplicado ou aplicável, em que no primeiro realiza coleta de dados geomorfológicos em função de um objeto de estudo e no segundo fornece informações que podem ser aplicadas, tornando-se elemento de interface entre os fatores formadores da paisagem (Christofoletti, 2011). A distribuição e comportamento geoespacial das feições geomorfométricas dependem do passado geológico e da geodinâmica ambiental atual, além de serem esculpidas por fases climáticas. A abordagem do planejamento territorial fundamentado em geoindicadores (forma, morfologia e morfometria, constituição litológica) traça um perfil ambiental (Goes et al. 2011).

Ao planejamento territorial é essencial a informação de capacidade de uso e ocupação da terra, que classifica quantitativamente as terras considerando as limitações e utilização da mesma, primordialmente nos efeitos do clima sobre o solo e sua resultante evolução e degradação, e nas características permanentes do solo, que em conjunto podem causar danos ao ambiente (Amaral, 1995). Mesmo sem o conhecimento científico é perceptível o avanço rápido da ocupação em áreas com condições topográficas favoráveis (Christofoletti, 2011), ou seja, a geomorfologia se relaciona com a capacidade de uso da terra.

Segundo Hartshorne (1978) uma porção da superfície da terra integra a heterogeneidade de fenômenos que distinguem uma área da outra, não apenas pelas relações entre o homem e a natureza, é a possibilidade de conhecer os lugares para entender sua dinâmica de transformação ao longo do tempo percebendo a alternação das feições no espaço (Moraes e Fernandes, 1980). Em termos históricos o uso e cobertura da terra possuem diferentes abordagens nos estudos, na década de 40 vinculado a colonização; entre 50 e 60 estudos espaciais da ocupação por produtos agrícolas e estudos regionais de aspectos geográficos; na década de 70 até meados de 80 o uso intensivo de técnicas de quantificação e de modelagem para uso das terras, por exemplo o Projeto Radam e RADAMBRASIL, que avaliaram a capacidade de uso da terra e recursos naturais com metodologias apoiadas em ponderações geomorfológicas, tipos de solos, da fisionomia da vegetação e do clima (Sokolonski e Domingues, 1998); e na década de 90 estudos da terra integrando diagnósticos e zoneamentos ambientais partindo da compreensão das características de dinâmica e objetivando identificar processos produtivos e impactos ambientais decorrentes (IBGE, 2013).

Segundo Silva (1995) o mundo pode ser entendido como estruturado de padrões espaciais que são analisados e classificados para facilitar a intensificação dos recursos 
naturais disponíveis neles, contudo é necessária a definição de parâmetros aceitáveis a diferentes atores sociais para que haja equilíbrio na interferência do homem no ambiente, sem que sua ocupação seja desordenada, com desperdício de recursos naturais e/ou poluição ambiental. Por isso a capacidade de uso da terra imprime caráter seletivo, racionalizador e de orientação ao uso da terra (Rodrigues et al., 2001). A classificação é interpretativa e feita para fins agrícolas, numa avaliação de objetivos gerais, representando um padrão para se avaliar a capacidade de suporte das terras com usos definidos generalizadamente (Ribeiro, 2007). Os grupos de capacidade de uso são definidos com base na maior menor intensidade de uso das terras, fundamentado nas relações entre tipos de utilização e características permanentes dos solos, expressa em termos de limitações e riscos (Ribeiro, 2007).

O estudo da capacidade de uso da terra usa a variável morfométrica declividade como um plano de informação para definir áreas destinadas a conservação ou que limitam o manejo (Formaggio et al., 1992;Assad, 1995; Rodrigues et al., 2001; Campos et al., 2002; Piroli E Campos, 2010), mais recentemente as pesquisas de Borges et al. (2007), Andres e Filho (2008), Piroli e Campos (2010) e IBGE (2013) enfatizam a relação entre a geomorfologia e a distribuição do uso e cobertura da terra, pontuando a funcionalidade do mapeamento geomorfológico - que avalia a declividade e outras variáveis, como altitude, aspecto e curvatura - aplicado ao estudo do uso e cobertura da terra por meio de geotecnologias, que permitem a periodicidade na geração de informação e o cruzamento de planos de informação muito mais práticos e acessíveis com as ferramentas de Sistemas de Informações Geográficas - SIG e o Geoprocessamento, agregando dinâmica, objetividade e rapidez na obtenção de mapas temáticos (Gomes et al., 1993). Uma oportunidade de entender como o espaço geográfico se organiza e interfere nos processos econômicos e sociais (Santos, 1980).

\subsection{AS TÉCNICAS DO MAPEAMENTO GEOMORFOLOGICO}

Para a geomorfologia as variáveis morfométricas são objeto de estudo com intenção de automatizar o mapeamento geomorfológico (Dragut e Blaschke, 2006; Camargo et al., 2001; Anders et al., 2001; Dragut, e Eisank, 2012) por que possuem relação com as classes mapeadas de solos, complemento de dados de conhecimento de solos e identificação de classes de vegetação (Qi e Zhu, 2003; Muñoz, 2009;Bispo et al., 2009).

A nível de mapeamento geomorfológico nacional o projeto RADAMBRASIL é muita vezes a única fonte de dados, mesmo em escala generalizada (1:100.000). 
3.1.1. Metodologia do IBGE - RADAMBRASILOs procedimentos básicos para o mapeamento geomorfológico proposto pelo IBGE (2009) são de carácter geral seguindo um fluxo que vai de estudo preliminar a geração de produtos.

A primeira etapa é a revisão de material gráfico e textual produzido para a área de interesse, selecionando informações de elementos da base cartográfica para o georreferenciamento de imagens a compor o arquivo gráfico, a seleção de imagens de sensores remotos adequados aos objetivos da pesquisa, consulta aos mapas de conhecimento geral da área e a análise geomorfológica de imagens de diferentes sensores identificando divergências e dúvidas.

A segunda etapa é a interpretação temática dividida em quatro eixos: 1) análise da drenagem em escala adequada permitindo inteirar nuances texturais; 2) interpretação de padrões e subpadrões de drenagem; 3) identificação e delimitação dos modelados e das formas de relevo; e 4) a elaboração de carta geomorfológica preliminar.

A terceira etapa é o trabalho de campo que abrange os percursos terrestres que complementam as informações obtidas nas etapas anteriores e tem o objetivo de sanar dúvidas devidamente assinaladas em material de campo. As informaçtões fornecidas pelo trabalho de campo devem descrever a paisagem caracterizando a vegetação, os modelados e a rede de drenagem, e registrar as formações superficiais para correlacionar aos processos morfogenético.

A quarta etapa é a reinterpretação e integração temática em que as informações coletadas em campo são incorporadas ao mapeamento geomorfológico alterando e atualizando as unidades mapeadas, da taxonomia e dos símbolos. É a etapa multidisciplinar que busca a compatibilização de elementos geográficos comuns a mais de um tema.

A quinta etapa é a edição gráfica em que os procedimentos de geoprocessamento são usadas para garantir a topologia na delimitação de elementos gráficos, identificar e corrigir inconsistências de limites. Nesta etapa os padrões estabelecidos para o mapeamento geomorfológico (taxonomia, cor, peso e estilo dos elementos).

As etapas seis, sete e oito são etapas desnecessárias ao usuário comum, em que na sexta etapa é a carga alfanumérica e gráfica no banco de dados do IBGE, o BDIA - Banco de Dados e Informações Ambientais - na escala 1:250.000 estruturado em SIG e em conformidade com a INDE - Infraestrutura Nacional de Dados Espaciais; a sétima etapa é a validação e consolidação dos dados carregados no banco, verificando a consistência dos dados quanto a simbologia e conformidade com os padrões usados para representação; a oitava e 
última etapa é a geração de produtos vetoriais de geomorfologia, carta geomorfológica final, cartas derivadas, estatísticas e indicadores ambientais e a síntese temática, todos os produtos na escala 1: 250.000 .

O produto final do usuário que aplica os procedimentos do IBGE (2009) é a carta geomorfológica e a escala pode variar de 1:250.000 a 1:50.000. O produto pode ser aplicado para as relações de evolução do relevo, indicação de sítios propícios a instalação de núcleos urbanos, da delimitação de áreas sujeitas a inundações e indicação de áreas em desequilíbrio morfodinâmico (IBGE, 2009).

\subsubsection{Mapeamento Geomorfológico do Goiás em 1991}

A variedade de aspectos morfogenéticos está relacionada aos fatores que contribuem, direta ou indiretamente, na construção do relevo por meios dos processos endogenéticos e exogenéticos. Nascimento (1991) propunha uma evolução paleogeográfica com três etapas, em que na primeira houve a ocorrência de dobramentos e rejuvenescimento do maciço no cilo Brasiliano. No eopaleozóico ocorrem as disposições de fácies marinhas na borda leste, correspondente à Bacia do Bambuí; na segunda a tectônica epirogênica responsável pelas deformações e ondulações de grande raio de curvatura e o preenchimento sinéclise do Paraná; por último a presença dos derrames balsáticos e intrusivas no Jurrássico-Cretáceo com posterior subsidência, que ocasionou a cobertura cretácea e as evidências de epirogênicas positivas pós-cretáceas ( responsável pela desnudação de vertentes e epigenia associadas aos soerguimentos dos paleoplanos modelados do Terciário).

Baseado na evolução paleogeográfica de Nascimento (1991), são individualizados três quadros morfoestruturais: 1) Maciços antigos anteriormente modelados por processos denudacionais anteriores e que passam por processos de aplainamento e reafeição no Cenozóico. São topograficamente configurados por planaltos, serras e depressões intermontanas. 2) Bacia de sedimentação representada por planaltos escarpados, mesas e chapadões. 3) Depressões pediplanadas que tem como característica grandes áreas de relevos planos e áreas de dessecação incipiente.

Partindo dessa proposta Nascimento (1991), ususfruindo dos dados obtidos com o Projeto RADAMBRASIL, identifica cinco unidades geomorfológicas e onze subunidades relacionadas a elas, conforme tabela abaixo (tabela 1 ). 
Tabela 1. Unidades Geomorfológicas e Subunidades Geomorfológicas do Goiás.

\begin{tabular}{ll}
\hline \multicolumn{1}{c}{ Unidades Geomorfológicas } & Subunidades Geomorfológicas \\
\hline Planalto Central Goiano & Planalto do Distrito Federal; \\
& Planalto do Alto Tocantins - Paranaíba \\
Planalto Setentrional da Bacia do Paraná & Planalto de Caiapônia; \\
Planalto do Divisor São Francisco/Tocantins & Planalto de Rio Verde \\
Depressão do Tocantins & Patamares do Chapadão \\
& Vão do Paranã; \\
Depressão do Araguaia & Depressão dos rios Maranhão / Santa Teresa \\
& Depressão do rio Araguaia; \\
\hline
\end{tabular}

\subsubsection{Mapeamento Geomorfológico do Goiás em 2005}

Em 2005 o autor Latrubesse realiza o mapeamento geomorfológico do Estado do Goiás usando técnicas de sensoriamento remoto e geoprocessamento com o uso de imagens IFSAR - Interferometric Synthetic Aperture Radar - para auxiliar na interpretação de geoformas, suas semelhanças e relações. Outros dados usados doram as cartas topográficas do IBGE em escala 1:250.000 com curvas de nível em equidistância de $100 \mathrm{~m}$, produtos derivados dos dados SRTM (perfis topográficos, relevo sombreado e hipsometria), mapa geológico e mapa de rede de drenagem. O mapeamento executou pesquisa de campo para validar e descrever geoformas da compartimentação geomorfológica.

Os produtos dos dados SRTM contribuíram para identificação de feições topográficas/ geomorfológicas diferentes, por exemplo, 1) o relevo sombreado simula diferentes geometrias em função da iluminação e permite identificar contatos litológicosm feições estruturais, zonas de erosão recuante, áreas de morros e colinas, padrões diferenciados de dissecação, feições planares, lineares positivo-negativo e tabulares; 2) o fatiamento altimétrico auxilia na identificação dos picos mais altos e das baixadas, como patamares diferenciados; 3)os perfis topográficos permitem uma rápida descrição das geoformas identificadas por suas irregularidades; e 4) o cruzamento dos dados de geologia, rede de drenagem e o fatiamento altimétrico .

O autor mapeia as unidades em Superfícies de Aplainamento Regional (SRA), Zonas de Erosão Recuante (ZER), Morros e Colinas (MC), Estruturas Dobradas (ED), Estruturas de blocos Falhados (BF), Estruturas em Estratos Horizontais e Sub-horizontais (EH), Sistemas Cársticos, Pseudo-domos (PSD), Outras Formas Dõmicas não Diferenciadas, Siatemas Lacustres e Planícies Fluviais.

As Superfícies Regionais de Aplainamento são as unidades mais representativas da geomorfologia do Estado do Goiás e a aplicação da categoria infere que seja denudacional gerada pelo arrasamento/aplinamento de uma superfície de terreno dentro de um intervalo de 
cotas. No Goiás estas superfícies são resultado dos processos de Etchplanação (Etchplains) ou por mistura de processos e não exclusivamente por pediplanação (pediplanos).

As Zonas de Erosão Recuante ocorrem entre as Superfícies Regionais de Aplainamento, e o grau de desenvolvimento depende da zona que está sendo erodida. A medida que uma zona de erosão recuante evolui uma paisagem de morros e colinas pode estar associada, iniciando um estágio evolutivo ainda incipiente para a geração de uma nova superfície de aplainamento.

Os Morros e Colinas quando visualizados em grandes áreas remetem as litologias remanescentes resistentes à erosão que se mantêm preservadas graças a um forte controle estrutural.

As Estruturas Falhadas ocorrem sobre rochas do Grupo Bambuí, do Arco Magnético e do Grupo Araxá. Os hogbacks no Vão do Paranã podem atingir até 500-600 m sobre o nível da superfície de aplainamento circundante, e os braquianticlinais da Serra da Mesa, Serra Dourada, Serra Branca e Serra do Encosto tem origem conjunta na ação das rochas intrusivas plutônicas que forma o núcleo da estrutura.

As Estruturas de Blocos Falhados apresenta rochas pré-crambianas com estruturas descritas antigas e sem estilo estrutural próprio.

As Estruturas em Estratos Horizontais e Sub-horizontais caracterizado por relevos tabulares em rochas sedimentares da Bacia do Paraná representados por chapadões de dissecação variando de fraca a média e grandes interflúvios. Relevos relacionados aos derrames basálticos da Formação Serra Geral. As rochas da Bacia do Paraná sofreram processos de aplainamento regional e como resultado as superfícies regionais de aplainamento e os relevos tabulares são considerados complementares da unidade.

Os Sistemas Cársticos estão associados às superfícies de aplainamento em rochas do Grupo Bambuí.

Os Pseudo-Domos apresentam morfologias geradas por estruturas tectônicas complexas sobre rochas pré-cambrianas. As Outras Formas Dômicas não Diferenciadas podem ser classificadas geomorfologicamente como inselbergs.Os Sistemas Lacustres possuem níveis lateríticos bem desenvolvidos e as Planícies Fluviais podem ser usadas como indicador de vulnerabilidade e valoração ambiental.

\subsubsection{Metodologia Aplicada}

A metodologia aplicada neste trabalho usa as variáveis morfométricas numa composição colorida para mapeamento das unidades geomorfológicas nas bacias 
hidrográficas do Rio das Almas (GO) e Rio Maranhão (GO/DF) e diferentemente do mapeamento proposto pelo IBGE (2009), Nascimento (1991) e Latrubesse (2005) os dados do sistema radar não são usados complementarmente às cartas topográficas, sombreamento do relevo ou fatiamento altimétrico, as variáveis morfométricas fornecem planos de informação sobre a área mapeada expressando em seus padrões os processos endógenos e exógenos, indicando morfoesculturas e processos morfogenéticos (Ross, 1992) e por expressarem diferentes características do relevo, resultando em um conjunto de dados, já bastam ao mapeamento (Valeriano, 2005).

Para Hermuche et al. (2002) a distribuição de elementos quantificados que descrevem as paisagens apresentam propriedades que se agrupam em padrões que caracterizam unidades fisiográficas e pedológicas. A autora usou a metodologia do realce de feições por meio de composição colorida das variáveis morfométricas da bacia estudada, Bacia do Rio Jardim - DF, para mapeamento das unidades pedológicas, assumindo que o ordenamento das classes de solos sofria forte influencia das variações morfométricas ao longo das vertentes nas bacias.

Demais autores como Hermuche et al. (2003), Castro et al. (2010a), Sousa Lima et al. (2009), Castro et al. (2010b), Passo et al.(2010) e Sena-Souza et al. (2013) também usaram a composição RGB para mapeamento das unidades geomorfológicas de diferentes localidades, sendo elas mais ou menos complexas, se comparadas.

O procedimento mantém constantes as variáveis altimetria e declividade nos canais $\mathrm{R}$ (vermelho) e G (verde), respectivamente, e no canal B (azul) é associada outra variável morfométrica, que pode ser curvatura, convexidade, aspecto e declividade. A combinação desses planos de informação derivam imagens que possibilitam distinguir as unidades de relevo baseando-se nas variações tonais e texturais (Borges et al., 2007; Panquestor et al., 2004; Hermuche et al., 2002) (figura 4).É selecionada a composição que melhor represente as características morfológicas da área de estudo usufruindo da interpretação visual das composições e dos conhecimentos acerca da área. 


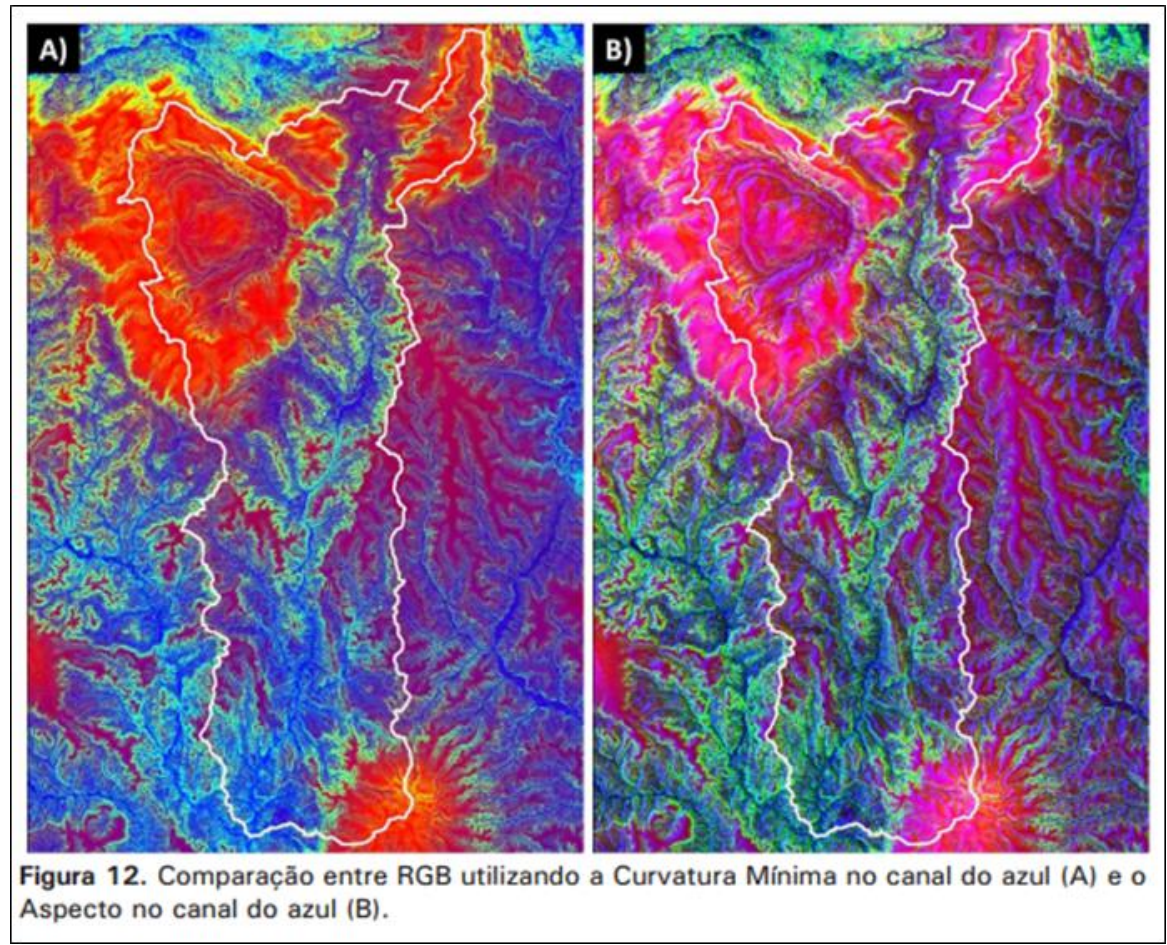

Figura 4. Composição colorida para digitalização manual das unidades geomorfológicas. Fonte: Sena-Souza, 2013.

O mapeamento, propriamente dito, das unidades geomorfológicas pode ser realizado de maneira manual, por digitalização das feições do modelado em tela ou por meio de classificação supervisionada e não supervisionada. No caso do mapeamento automático após a obtenção da imagem de classificação esta é convertida em formato vetorial (Castro et al., 2010). O que define a aplicação do mapeamento automático ou mapeamento por digitalização é a extensão da área de estudo, em que áreas de maior extensão requerem mais tempo e incorpora-se maior subjetividade dos analistas envolvidos no processo de mapeamento.

Hierarquicamente são identificados no processo de mapeamento das unidades geormofológicas os Domínios Morfoestruturais ( $1^{\circ}$ nível), as Regiões Geomorfológicas ( $2^{\circ}$ nível), e as Unidades Geormorfológicas ( $3^{\circ}$ nível), também conhecidos como compartimentos do relevo (IBGE, 2009). 
A figura 5 mostra o resultado do mapeamento das unidades geomorfológicas usando a composição colorida para realce das feições do modelado e a associação com as informações relativas aos táxons de classificação segundo IBGE. Os resultados são do autor Sena-Souza (2013).

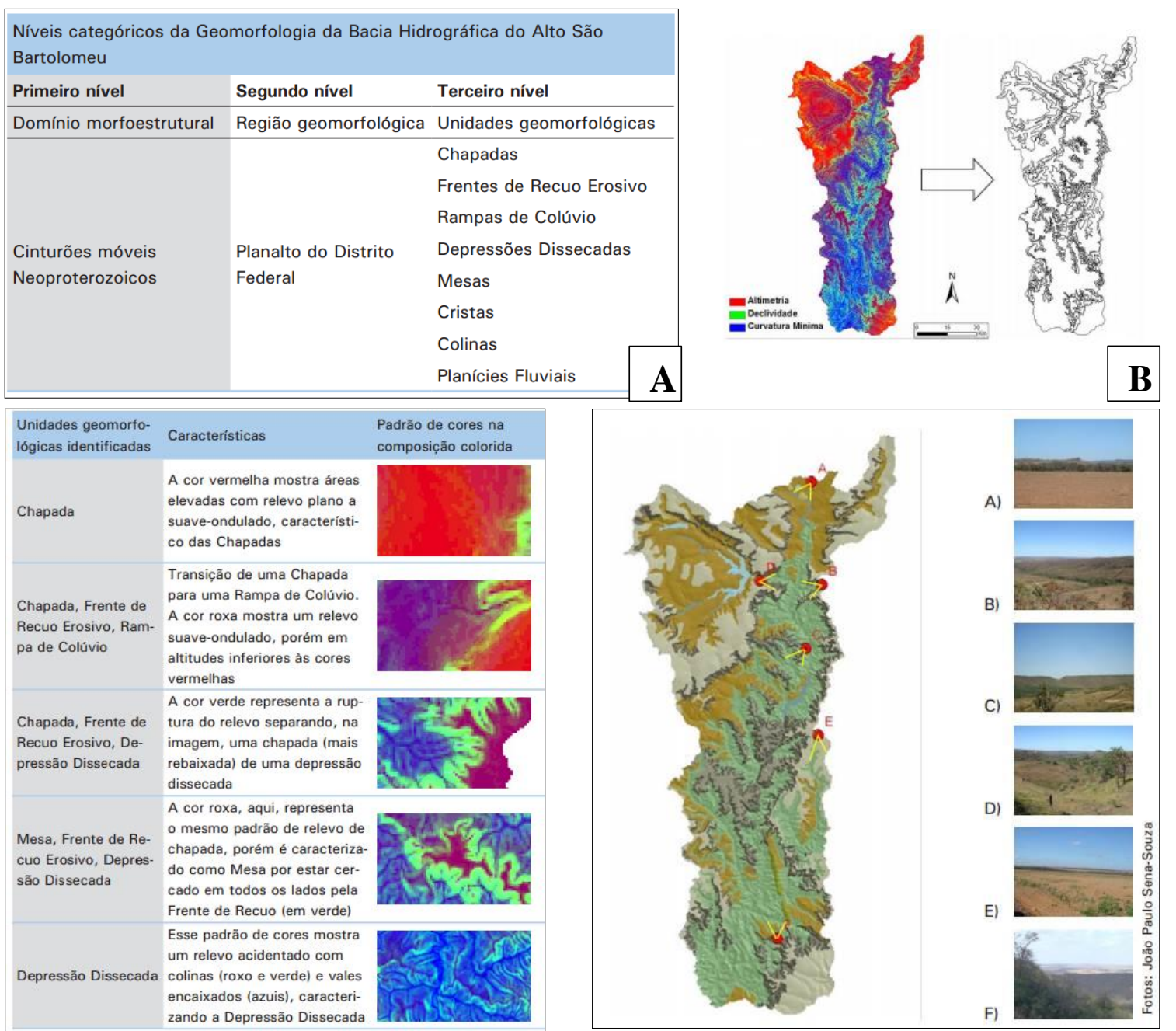

Figura 5. Classificação geomorfológica segundo IBGE (2009); B) Resultado da digitalização das unidades geomorfológicas usando composição colorida das variáveis morfométricas; C) Unidades geomorfológicas identificadas na Bacia do Rio São Bartolomeu (Sena-Souza, 2013); D) Validação em campo.

O relevo é um elemento de condicionamento sobre o desenvolvimento das civilizações com participação ativa na fisiografia terrestre, e as variáveis geomorfométricas se constituem como componentes do meio natural, servindo de suporte para o estabelecimento e proporcionado recursos para o crescimento das atividades. Enquanto ramo científico a geomorfologia está voltada aos aspectos morfológicos da topografia e da dinâmica responsável pelo funcionamento e esculturação da paisagem; e como um elemento do meio físico é determinante às organizações espaciais e atividades humanas (Girão e Corrêa, 2004). 
As feições geomorfológicas e seus processos morfogenético são relevantes para as categorias de uso e cobertura e por isso o conhecimento da dinâmica morfológica aplica-se ao diagnóstico das condições ambientais (Girão e Corrêa, 2004), pois o relevo constitui-se como suporte concreto de interações naturais e sociais (Casseti, 1995). 


\section{REFERÊNCIAS BIBLIOGRÁFICAS}

Almeida Filho, R.; Miranda, F.P. Mega capture of the Rio Negro and formation of the Anavilhanas Archipelago, Central Amazônia, Brazil: Evidences in an SRTM digital elevation model. Remote Sensing of Environment, v.110, p.387-392. 2007.

Almeida Filho, R.; Moreira, F.R.S.; Beisl, C.H. The Serra da Cangaiha astrobleme as revealed by ASTER and SRTM orbital data. International Journal of Remote Sensing, v.26, p.833838. 2005.

Alves, L.N.; Galo, M E Trindade, M.L.B.G. Fundamentos do processamento interferométrico de dados de radar de abertura sintética. In: Anais XIV Simpósio Brasileiro de Sensoriamento Remoto, p. 7227-7234. INPE - Natal. Abril, 2009.

Amaral, J.A.B. Prognóstico da capacidade de uso da planície de inundação do Rio Paraná (compartimento "canal cortado"). Dissertação (Mestrado), Universidade de São Paulo. São Carlos, 1996.

Anders, F.F.M.; Seijmonsbergen, A.C.; Boutten, W. Segmentation optimization and straified object-based analysis for semi-automated geomorfphological mapping. Remote Sensing of Environment, v. 115, n. 12, p. 2976-2985, 2011.

Andres, J.; Filho, J.A.M. Metodologia para o planejamento do uso da terra por meio do geoprocessamento.Ambiência, v.4, n.1, p. 13-24, 2008.

Argento, M.S.F. Mapeamento geomorfológico. In: GUERRA, A.J.T.; CUNHA, S.B.(Org). Geomorfologia: uma atualização de bases e conceitos. Rio de Janeiro: Bertrand Brasil, p.365386. 2011.

Arruda , M.B.; Proença, C.E.; Rodrigues, S.; Campos, R.N.; Martins, R.C.; Martins, E.S. Ecorregiões, Unidades de Conservação e Representatividade Ecológica do Bioma Cerrado, In: Ribeiro, J.F. Walter, T.M.B.; Sano, S. (Orgs.). Fitofisionomias do bioma Cerrado. Cerrados: ambiente e flora. $2^{\circ}$ ed., Planaltina: Embrapa, 2006.

Assad, M.L.L. Uso de sistemas de informações geográficas na determinação da aptidão agrícola de terras. Revista Brasileira de Ciência do Solo, v. 19, p. 133-139, 1995.

Barros, R.S. Avaliação da Altimetria de Modelos Digitais de Elevação Obtidos a Partir de Sensores Orbitais. Dissertação (Mestrado). Universidade Federal do Rio de Janeiro. Rio de Janeiro, 2006.

Bertrand, G. Paisagem e Geografia Física global: esboço metodológico. São Paulo. Instituto de Geografia - USP. Cadernos de Ciências da Terra, v. 13, 27f. São Paulo, 1972.

Bhang, K.J.; Schwartz, F.W.; Park, S.S. Estimating historic lake stages from one-time snapshot, the shuttle radar topography mission of 2000. Hydrological Processes, v. 24, p. 1834-1843. 2010.

Birkinshaw, S.J.; O’donnell, G.M.; Moore, P.; Kilsby, C.G.; Fowler, H.J.; Berry, P.A.M. Using satellite altimetry data to augment flow estimation techniques on the Mekong River. Hydrological Processes, v. 24 (26), p. 3811-3825. 2010.

Bispo, P.C.; Valeriano, M.M.; Kuplich, T.M. Variáveis geomorfométricas locais e sua relação com a vegetação da região do interflúvio Madeira-Purus (AM-RO). Acta Amazônica, v. 39, n. 1. P. 81-90, 2009. 
Borges, M.E.S.; Carvalho Júnior, O.A.; Martins, E.S.; Arcoverde, G.F.B.; GUIMARÃES, R.F.; GOMES, R.A.T. Emprego do processamento digital dos parâmetros morfométricos no mapeamento geomorfológico da bacia do Rio Preto. Revista Espaço e Geografia, v. 10, n. 2, p. 401-429. 2007.

Borges, N.G. Mapeamento geomorfológico da bacia do rio Preto e sua relação com uso agrícola. Dissertação (Mestrado) Universidade de Brasília, Brasília, DF. 2008.

Camargo, F.F.; Almeida, C.M.; Florenzano, T.G.; Heipke, C.; Feitosa, R.Q.; Costa, G.A.O.P. ASTER/Terra Imagery and a MultilevelSemantic Network for Semi-automated Classification of Landforms in a Subtropical Area. Photogrammetric Engineering e Remote Sensing, v.77, n. 6, p. 619-629, 2011.

Campos, S.; Santos, T. S.; Silva, C. L.; Barros, Z. X.; Cardoso, L.G. Capacidade de uso das terras da bacia do Ribeirão Água Fria - Bofete (SP). Revista Irriga, v. 7, n.2, 2002.

Cárdenas, F.P.A. Zoneamento Geoambiental de uma parte da Bacia do Rio Nechí Colômbia, por meio de técnicas de Geoprocessamento. Dissertação (Mestrado), Instituto de Geociências, Universidade de Brasília, DF. 1999.

Carvalho Junior, O.A.; Sampaio, C.S, Silva, N.C.; Couto Júnior, A.F.; Gomes, R.A.T.; Carvalho, A.P.F.; Shimabukuro, Y.E. Classificação de padrões de savana usando assinaturas temporais NDVI do sensor MODIS no Parque Nacional da Chapadas dos Veadeiros. Revista Brasileira de Geofísica, v. 26, p. 505-517, 2008.

Casseti, V. Introdução a geomorfologia. [S.1.]: [2005]. Disponível em: <http://www.funape.org.br/geomorfologia/>. Acesso em: 15 de novembro de 2014.

Castro, K.B.; Martins, E.S.; Gomes, M.P.; Reatto, A.; Lopes, C.A.; Passo, D.P.; Sousa Lima, L.A.; Carvalho Junior, O.A.; Trancoso Gomes, R.A. Caracterização Geomorfológica do Município Luís Eduardo Magalhães, Oeste Baiano, escala 1:100.000. Brasília. Embrapa Cerrados, 2010, 32 p. (Boletim de Pesquisa e Desenvolvimento, n. 288).

Castro, K.B.; Martins, E.S.; Gomes, M.P.; Reatto, A.; Passo, D.P.; Sousa Lima, L.A.; Carvalho Junior, O.A.; Trancoso Gomes, R.A. Carcaterização Geomorfológica do Município de Jaborandi, Oeste Baiano, escala 1:100.000. Brasília. Embrapa Cerrados, 2010, 32 p. (Boletim de Pesquisa e Desenvolvimento, n. 285).

Cavalcante, A.A.; Cunha, S.B. Morfodinâmica fluvial em áreas semiáridas: discutindo o Vale do Rio Jaguaribe- CE- Brasil. Revista Brasileira de Cartografia, v.13, n; 1, p. 39-49. 2012.

Chagas, C.S.; Fernandes Filho, E.I.; Rocha, M.F.; Júnior, W.C.; Neto, N.C.S. Avaliação de modelos digitais de elevação para aplicação em um mapeamento digital de solos. Revista Brasileira de Engenharia Agrícola e Ambiental, v.14, p.218-226. 2010.

Chaplot, V.; Darboux, F.; Bourennane, H.; Leguedois, S.; Silveira, N.; Phachomphon, K. Accuracy of interpolation techniques for the derivation of digital elevation models in relation to landform types and data density. Geomorphology, v. 77, p. 126-141, 2006.

Costa, F.R.; Rocha, M.M. Geografia: conceitos e paradigmas - apontamentos preliminares. Revista GEOMAE: geografia, meio ambiente e ensino, v.1, n.2, p.25-56, 2010.

Couto Júnior, A.F.; Carvalho Júnior, O.A.; Martins, E.S. Séries temporais de NDVI, EVI e NDWI do sensor MODIS para caracterização fenológica algodão. Revista Brasileira de Cartografia $\mathrm{n}^{\circ}$ 65, v. 1, p. 199-210. 2013.

Couto Júnior, A.F.; Carvalho Júnior, O.A.; Martins, E.S. Integração de parâmetros morfométricos e imagem ASTER para a delimitação das fitofisionomias da Serra da Canastra, 
Parque Nacional da Serra da Canastra, MG. Revista Brasileira de Cartografia $\mathrm{n}^{\mathrm{o}}$ 1, v. 11, p. 57-68. 2010.

Couto Júnior, A.F.; Carvalho Júnior, O.A.; Martins, E.S. Séries temporais MODIS aplicadas em sucessão de culturas de soja (Glycine $\max ($ L.) Merrill) e milho (Zea mays L.) em sistema de plantio direto. Revista Brasileira de cartografia $n^{\circ}$ 64, v. 3, p. 405-418. 2012

Couto, G. S. Cana-de-açúcar em Goiás: problema ou potencialidade. In: IX Simpósio Nacional Cerrado: Desafios e estratégias para o equilíbrio entre sociedade, agronegócio e recursos naturais e II Simpósio internacional Savanas Tropicais. Organização: Embrapa Cerrados. Brasília. 2008.

Cristofoletti, A. Impactos no meio ambiente ocasionados pela urbanização no mundo tropical. In: Natureza e sociedade de hoje: uma leitura geográfica. $2^{\circ}$ Edição. São Paulo: Hucitec Anpur. 1994.

Cruz, O. A ilha de Santa Catarina e o continente próximo: um estudo de geomorfologia costeira. Florianópolis: Editora da UFSC, 1998. p. 276.

Donzeli, P.L.; Moraes, J.F.L.; Menk, J.R.F.; Fernandez, G.A.V. Gestão Ambiental integrada do bico do papagaio: aptidão agrícola da folha SB: 22-Z-B, Xambioá, TO. 2003.

Dragut, L.; Blaschke, T. Automated classification of topography from SRTM data. Geomorphology, v. 141-142, n. 1, p. 21-23, 2012.

Dragut, L.; Eisank, C. Automated classification of landform elements using object-based image analysis. Geomorphology, v.81, n. 3-4, p. 330-344, 2006.

Elesbon, A.A.A.; Guedes, H.A.S.; Silva, D.D.; Oliveira, I.C. Uso de dados SRTM e plataforma SIG na caracterização morfométrica da bacia hidrográfica do Braço Norte do Rio São Mateus - Brasil. REM: Revista Escola de Minas, v. 64(3), p. 281-288. 2011.

Farr, T.G.; Kobrick, M. Shuttle Radar Topography Mission produces a wealth of data. EOS (Transactions, American Geophysical Union), v. 81, p. 583-585. 2000.

Farr, T.G.; Rosen, P.A.; Caro, E.; Crippen, R.; Duren, R.; Hensley, S.; Kobrick, M.; Paller, M.; Rodriguez, E.; Roth, L.; Seal, D.; Shaffer, S.; Shimada, J.; Umland, J.; Werner, M.; Oskin, M.; Burbank, D.; Alsdorf, D. The Shuttle Radar Topography Mission. Review of Geophysics, v. 45. 2007.

Fayad, I.; Baghdadi, N.; Gond, V.; Bailly, J.S.; Barbier, N.; El Hajj, M.; Fabre, F. Coupling potential of ICEsat/GLAS and SRTM for ther discrimination of forest landascape types in French Guiana. International Journal of Applied Earth Observation and Geoinformation, v. 33, p. 21-31. 2014.

Fernandes da Silva, F; Candeias, A. L.B. Dados SRTM: Como utilize-los? Um exemplo na Ilha sw Itamaracá. COBRAC, 2006.

Fisher, P. F.; Tate, N. J. Causes and consequences of error in digital elevation models. Progress in Physical Geography, v. 30, n. 4, p. 467-489, 2006.

Florenzano, T.G. Sensoriamento remoto para geomorfologia. In:FLORENZANO, T.G. (Org). Geomorfologia: conceitos e tecnologias atuais. São Paulo, 2008. p. 36-65.

Formaggio, A.R.; Alves, D. S.; Epinhanio, J. C. N. Sistemas de informações geográficas na obtenção de mapas de aptidão agrícola e de taxa de adequação de uso das terras. Revista Brasileira de Ciência do Solo, v. 16, p. 249-256, 1992. 
Gastão, F.G.C.; Maia, L.P. O uso de dados da missão SRTM e sedimentológicos nos estudos de geomorfologia e padrões de drenagem na região dos Lençóis Maranhenses. Revista Brasileira de Cartografia, n. 62, v. 2, p. 14. 2010.

Girão, O. ; Corrêa, A.C.B. A contribuição da geomorfologia para o planejamento da ocupação de novas áreas. Revista de Geografia, v. 21, n. 2, p. 36-58, 2004.

Goergen, L.C.G.; Schuh, M.S.; Pereira, R.S. Comparação entre delimitação manual e automática da bacia do Arroio Corupá, RS, Brasil. Revista Eletrônica em Gestão, Educação e Tecnologia Ambiental, v. 8 (8), p. 1777-1784, 2012.

Gomes, E.C.B.; Leite, F. R. B.; Cruz, M. L. B. Aptidão agrícola das terras através de sistema de informações geográficas. Folha SB.24-X-A-I-4- Barreira.In: Anais do VII Simpósio Brasileiro de Sensoriamento Remoto.1993. p.132-139.

Grohmann, C.H.; Riccomini, C.; Alves, F.M. Srtm-based morphotectonic analysis of the Poços de Caldas Alkaline Massif, southeastern Brazil. Computers e Geosciences, v.33, p.1019.2007.

Grohmann,C.H.; Steiner, S.S. SRTM resample with short distance-low nugget kriging. International Jornaul or Geographical Information Sciencen.v. 22, p. 895-906.2008.

Hartshorne, R. Propósitos e natureza da geografia. Tradução de Thomaz N. Neto. São Paulo: Hucitec, 1978.

Harvey, D. Explanation in geopraphy. London: Edward Arnold, 1969. P. 521.

Hermuche, P.M.; Guimarães, R.F.; Carvalho, A.P.F.; Martins, E.S.; Druck, S.; Carvalho Júnior, O.A.; Ferreira Dos Santos, N.B.; Reatto, A. Morfometria como suporte para elaboração de mapas pedológicos: I. Bacias hidrográficas assimétricas. Brasília. Embrapa Cerrados, 2002, 2 p. (Documentos, 68)

Hermuche, P.M.; Guimarães, R.F.; Carvalho, A.P.F.; Martins, E.S.; Druck, S.; Carvalho Júnior, O.A. Processamento digital de imagens morfométrica para subsidiar o mapeamento pedológico In: Anais XI Simpósio Brasileiro de Sensoriamento Remoto, Belo Horizonte, p. 123-130. (Org.) INPE, Brasil, 2003.

Ibanez, D.M.; Miranda, F.P.; Riccomini, C. Geomorphometric pattern recognition of SRTM data aplied to the tectonic interpretation of the Amazonian landscape. ISPRS Journal of Photogrammetry and Remote Sensing, v. 87, p. 192-204. 2014.

IBGE - Instituto Brasileiro de Geografia e Estatística. Manual Técnico em geociências n. 5: Manual Técnico de Geomorfologia. $2^{\circ}$ Edição, p.182. Rio de Janeiro. 2009.

Iorio, M.M.; Lastoria, G.; Mioto, C.L.; Albrez, A.; Paranhos Filho, A.C. Avaliação de modelos digitais de elevação extraídos de imagem ALOS/PRISM e comparação com os modelos disponibilizados gratuitamente na web. São Paulo, UNESP, Revista de Geociências, n 4 , v.31, p. 650-664. 2012.

La Blache, P.V. Princípios da geografia humana. Lisboa: Cosmos, 1954.

Leite, M.E.; Almeida, W.L.; Silva, R.F. Geotecnologias aplicadas à extração automática de dados morfométricos da bacia do Pacuí, MG. Revista Brasileira de Cartografia, $\mathrm{n}^{\circ}$ 64, v. 5 , p. 677-691. 2012.

Li, P.; Shi, C.; Li, Z.; Muller, J.; Drummond, J.; Li, X.; Li, T.; Li, Y.; Liu, J. Evaluation of ASTER GDEM using GPS benchmarks and SRTM in China. International Journal of Remote Sensing, ${ }^{\circ}$ 5, v.34, p.1744-1771.2013. 
Li, S.; Sun, D.; Goldberg, M.; Stefanidis, A. Derivation of $30 \mathrm{~m}$ resolution water maps from TERRA/MODIS and SRTM. Remote Sensing of Environment, no 134, p. 417-430. 2013.

Lillesand, T. M.; Kiefer, R. W.; Chipman, J. W. Remote sensing and image interpretation. New York: John Wiley \& Sons, 2004. 763 p.

Lopes, H.L.; Cabral, J.J.S.P.; Araújo Filho, J.C.; Montenegro, S. M. G. L. Mapeamento de áreas aluvionares no seminárido brasileiro por meio de dados colaterais e imagens orbitais. Revista Brasileira de Engenharia Agrícola e Ambiental, v.17(7), p.763-769. 2013.

Martins, E.S.; Reatto, A.; Carvalho Junior, O.Sa.; Guimarães, R.F. Ecologia de Paisagem: conceitos e aplicações potenciais no Brasil. Brasília. Embrapa Cerrados, 2004, 35 p. (Documentos, 121).

Martins, E.S.; Reatto, A.; Carvalho Junior, O.Sa.; Guimarães, R.F. Evolução geomorfológica do Distrito Federal, escala 1:100.000. Brasília. Embrapa Cerrados, 2004, 57 p. (Documentos, 122).

Medeiros, L.C.; Ferreira, N.C.; Ferreira, L.G. Avaliação de modelos digitais de elevação para delimitação automática de bacias hidrográficas. Revista Brasileira de Cartografia, $\mathrm{n}^{\circ} 61$, v.2, p. 137-151. 2009.

Merino, E.R.; Assine, M.L.; Pupim, F.N. Estilos fluviais e evidências de mudanças ambientais na planície do Rio Miranda, Pantanal. Revista Brasileira de Geomorfologia, v. 14(2), p. 127-134. 2013.

Miceli, B.S.; Dias, F.M.; Seabra, F.M.; Santos, P.R.A.; Fernandes, M.C. Avaliação vertical de modelos digitais de elevação (MDEs) em diferentes configurações topográficas para médias e pequenas escalas. Revista Brasileira de Cartografia, n.63 (1), p. 191-201. 2011.

MIRANDA,E.E.De; (Coord.). Brasil em Relevo. Campinas: Embrapa Monitoramento por Satélite, 2005. Disponível em: 〈http://www.relevobr.cnpm.embrapa.br>. Acesso em: 27 out. 2014.

Moraes, A. C. R.; Fernandes, F. A Antropogeografia De Ratzel: Indicações. São Paulo: Hucitec, P. 7-30, 1990.

Moura, L.Z.; Bias, E.S.; Brites, R. Avaliação da acurácia vertical de modelos digitais de elevação (MDES) nas bacias do Paranoá e São Bartolomeu. Revista Brasileira de Cartografia, $n^{\circ}$ 66/1, p. 1-14. 2014.

Muñoz, V. A. Análise geomorfológica de dados SRTM aplicada ao estudo das relações solorelevo

Nikolakopoulos, K.G., Kamaratakis, E.K., Chrysoulakis, N. Srtm vs ASTER elevation products. Comparison for two regions in Crete, Greece. International Journal of Remote Sensing, v. 27 (21), p. 4819-4838. 2006.

Oliveira, J. H. M.; Chaves, J. M. Mapeamento e caracterização geomorfológica: Ecorregião Raso da Catarina e entorno NE da Bahia. Mercator, v. 9, n. 20, 2010.

Oliveira, P.T.S; Sobrinho, T.A.; Steffen, J.L.; Rodrigues, D.B.B. Caracterização morfométrica de bacias hidrográficas através de dados SRTM. Revista Brasileira de Engenharia Agrícola e Ambiental, v. 18(8), p. 819-825. 2010.

Pan, F.; Liao, J.; Li, X.; Guo, H. Application of the inundation area- lake level rating curves constructed from the SRTM MDE to retrieving lake levels from satellite measured inundation areas. Computers \& Geosciences, v. 52, p.168-176. 2013. 
Panquestor, E.K.; Carvalho Júnior, O.A.; Ramos, V.M.; Guimarães, R.F.; Martins, E.S.; Aplicação de indicadores quantitativos na definição de unidades de paisagem e uso da terra na bacia do Rio Corrente - BA. In: Encontro Nacional da Associação Nacional de PósGraduação e Pesquisa em Ambiente e sociedade, v. 2, p. 1-16, 2004.

Paranhos Filho, A.C.; Lastoria, G.; Torres, T.G. Sensoriamento Remoto Ambiental Aplicado. Campo Grande: Editora UFMS, 2008.

Passo, D.P.; Martins, E.S.; Gomes, M.P.; Reatto, A.; Castro, K.B.; Sousa Lima, L.A.; Carvalho Junior, O.A.; Trancoso Gomes, R.A. Caracterização Geomorfológica do Município de Barreias, Oeste Baiano, Escala 1:100.000. Brasília. Embrapa Cerrados, 2010, 30 p. (Boletim de Pesquisa e Desenvolvimento, 294).

Polizel, S.P.; Rpssetti, D.F. Caracterização morfológica do delta do Rio Doce (ES) com base em análise multissensor. Revista Brasileira de Geomorfologia, v. 15(2), p. 311-326. 2014.

Qi, F.; Zhu, A. Knowledge Discovery from soil maps using inductive learning. International Journal of Geographical Information Science, v. 17, n. 8, p. 771-795, 2003.

Rabus, B.;Eineder, M.; Roth, R.; Banker, R. The Shuttle Radar Topography Mission - a new class of digital elevation models acquired by spaceborne radar. ISPRS Journal of Photogrammetry \& Remote Sensing, v. 57, p. 241-262. 2003.

Ratter, J.; Ribeiro, J.; Bridgewater, S. The Brazilian Cerrado vegetation and threats to its biodiversity. Annals of Botany, no 80, p. 223-230. 1997.

Rebelo, C.R. Aplicação do InSAR na geração de modelos digitais de terreno. Dissertação (Mestrado). Universidade de Lisboa, Faculdade de Ciências, Departamento de Matemática, p. 1-214. 2007.

Ribeiro, M.R. Metodologias de avaliação da aptidão agrícola das terras e as variáveis regionais. In: Anais da Academia Pernambucana de Ciência Agronômica, v. 4,p. 116-125, 2007.

Robaina, L.E.S.; Tretin, R.; Bazzan, T.; Reckziegel, E.W.; Verdum, R. Nardin, D. Compartimentação geomorfológica da bacia hidrográfica do Ibicuí, Rio Grande do Sul, Brasil: Proposta de classificação. Revista Brasileira de Cartografia, v. 11(2), p. 11-23. 2010.

Rocha, R.M.; Lucas, A.A.T.; Almeida, C.A.P.; Neto, E.L.M.; Netto, A.O.A. Caracterização morfométrica da sub-bacia do rio Poxim-Açu, Sergipe, Brasil. Revista Ambiente e Água, v. 9(2), p. 276-287. 2014.

Rodrigues, R. B. T.; Zimback, C.R.L.; Piroli, E. L. Utilização de sistemas de informação geográfica na avaliação do uso da terra em Botucatu (SP). Revista Brasileira de Ciência do Solo, Viçosa, v. 25, p. 675-681, 2001.

Rodriguez, E.; Morris, C.H.; Belz, J.E. A global assessment of the SRTM performance. Photogrammetric Engineering and Remote Sensing, v.72, p. 249-260. 2006.

Rosen, P.A.; Hensley, S.; Joughin, I.R.; Li, F.K.; Madsen, S.N.; Rodriguez, E.; Goldstein, R.M. Synthetic aperture Radar interferometry. Proceedings of the Institute of Electrical and Electronics Engineers - IEEExplore, v. 88, n. 3, p. 333-382. 2000.

Salgado, M.P.G.; Formaggio, A.R.; Rudorff, B.F.T. Avaliação dos dados SRTM aplicados à modelagem do fator topográfico da USLE. Revista Brasileira de Cartografia, v. 4, n. 64, p. 429-442. 2012. 
Sano, E.E.; Santos, C.C.M; Silva, E.M.; Chaves, J.M. Fronteira agrícola do oeste baiano: considerações sobre os aspectos temporais e ambientais. Geociências, v. 30, nº 3, p. 479-489. São Paulo. 2011.

Santos, A. P.; Niero, M.; Lombardo, M. A. Interpretação de dados de sensoriamento remoto no uso da terra. In: Introdução às técnicas de sensoriamento remoto e aplicação: curso de treinamento. São José dos Campos: INPE, 1980. p.318.

Santos, M.; Silveira, M.L. O Brasil: território e sociedade no inicío do século XXI. Rio de Janeiro: Record, 2004.p. 473.

Sena-Souza, J.P.; Martins, E.S.; Couto Júnior, A.F.; Reatto, A.; Vasconcelos, V.; Gomes, M.P.; Carvalho Junior, O.A.; Reis, A.M. Mapeamento Geomorfológico da Bacia Hidrográfica do Rio são Bartolomeu, escala 1:100.000. Brasília. Embrapa Cerrados, 2013, 38 p. (Boletim de Pesquisa e Desenvolvimento, 314).

Shafique, M., Van Der Meijde, M; Kerle, N.; Van Der Meer, P. Impact of DEM source and resolution on topographic seismic amplification. International Journal of Applied Earth Observation and Geoinformation, v. 13(3), p. 420-427. 2011.

Sharma, A., Tiwari, K., Bhadoria, P. Quality assessment of contour interpolated digital elevation models in a diverse topography. International Journal of Ecology e Development, v. 15, p. 26-42. 2010a.

Sharma, A., Tiwari, K., Bhadoria, P. Vertical accuracy of digital elevation model from Shuttle Radar Topographic Mission-a case study. International Journal of Ecology e Development, v. 15, p. 26-42. 2010 b.

Sharma, A.; Tiwari, K.N. A comparative appraisal of hydrological behavior os SRTM DEM at catchment level. Journal of Hydrology, n.519, p. 1394-1404. 2014.

Shortridge, A.; Messina, J. Spatial structure and landscape associations of SRTM error. Remote Sensing of Environment, v. 115, p. 1576-1587. 2011.

Silva, C.L.; Moralles, N.; Crósta, A.P.; Costa, S.S.; Jiménez-Rueda, J.R. Analysis of tectoniccontrolled fluvial morphology and sedimentar processes of western Amazon Basin: na approach using satellite images and digital elevation model. Anais da Academia Brasileira de Ciências, v. 79 (4), p. 693-711. 2007.

Silva, C.R.; Pacheco, A.P.; Valente, S. Análise de dados SRTM e imagens CBERS 2b na identificação de áreas susceptíveis à ocupação irregular em faixa de servidão de linha de transmissão de energia elétrica. Revista do Centro de Ciências Naturais e Exatas, v.36(2), p. 128-136. 2014.

Silva, D.R.V.; Amaro, V.E. Integração entre dados ópticos e radar (SRTM) para a caracterização geoambiental da costa setentrional do Rio Grande do Sul. Revista de Geografia Acadêmica, v. 2(2), p. 111-123. 2008.

Silva, F.; Fraiñas, M. R.;Felfili, J. M.; Flinc, C. A. Spatial heterogeneity, land use and conservation in the Cerrado region of Brazil. Journal of Biogeography, v. 33, p. $536-548$. 2006.

Silva, J.; Bates, J. Biogeographic patterns and conservation in the South American Cerrado: A tropical savanna hotspot. Bioscience, $n^{\circ}$ 52, p. 225- 233. 2002

Silva, J.X. A pesquisa ambiental no Brasil: uma visão crítica. Cadernos de Geociências, n. 14, p. 15-27, 1995. 
Silva, J.X. Geomorfologia e geoprocessamento. In: GUERRA, A.J.T.; CUNHA, S.B.(Org). Geomorfologia: uma atualização de bases e conceitos. Rio de Janeiro: Bertrand Brasil, p.365386. 2011.

Smith, L.C., Pavelsky, T.M. Remote sensing of volumetric storage changes in lakes. Earth Surface Processes and Landforms, v.34, p.1353-1358. 2009.

Sobrinho, T.A.; Oliveira, P.T.S.; Rodrigues, D.B.B.; Ayres, F.M. Delimitação automática de bacias hidrográficas utilizando dados SRTM. Revista de Engenharia Agrícola de Jaboticabal, v.30 (1), p. 46-57. 2010.

Sokolonski, H.H.; Fomingues, E. Uma síntese dos estudos do uso da terra no IBGE. In: Semana Nacional do Meio Ambiente - Senama, Rio de Janeiro, 1998.BORGES, M.E.S. Relação dos compartimentos geomorfológicos com o uso agrícola na bacia do Rio Preto. Espaço e Geografia, v. 10, n. 2, p. 453- 476, 2007.

Souza Lima, L.A.; Martins, E.S.; Reatto, A.; Castro, K.B.; Vasconcelos, V.; Carvalho Junior, O.A. Compartimentação Geomorfológica e suas relações com solos na Bacia do Alto Rio Preto, GO. Brasília. Embrapa Cerrados, 2009, 25 p. (Boletim de Pesquisa e Desenvolvimento, 255)

Steiner, S.S. Aquisição e processamento de dados morfométricos derivados do modelo digital de elevação SRTM. Dissertação (Mestrado). Universidade de São Paulo, Instituto de Geociências. São Paulo, 2007.

Suertegaray, D.M.A.; Nunes, J.O.R.A. A natureza da geografia física na geografia. Terra Livre, n.17, p. 11-24, 2001.

Teixeira, S.G.; Souza Filho, P.W.M. Mapeamento de ambientes costeiros tropicais (Golfão Maranhense, Brasil) utilizando imagens de sensores remotos orbitais. Revista Brasileira de Geofísica, v. 27(1), p. 69-82. 2009.

Thomas, J.; Joseph, S.; Thrivikramji, K.P.; Arunkumar, K.S. Sensitvity of digital elevation models: the scenario from two tropical mountain river basins of Western Ghats, India. Geoscience Frontiers, n. 5, p. 893-909. 2014.

Toutin, T; Gray, L. State- of - Art of Elevation Extraction from Satellite SAR Data. ISPRS Journal of Photogeammetry \& Remote Sensing, v.55, p. 13-33.2000.

Tretin, R.; Robaina, L.E.S.; Sccoti, A.A.V. Mapeamento geomorfológico do município de Manoel Viana - Oeste do Rio Grande do Sul - Brasil. Revista de Geociências, v. 32(2), p. 333-345. 2013

Tuner,M.G.; Gardner, R.H. Quantitative methods in landscape ecology: Na introduction. In: TURNER, G.M.; GARDNER,R.H. Quantitative methods in landscape ecology: The analyses and interpretation of landscape heterogeneity. New York: Springer Verlag, p. 3-16, 1991.

Umetsu, R.K.; Pereira, N.; Campos, E.M.F.P.; Umetsu, C.A.; Mendonça, R.A.M.; Bernasconi, P.; Camargo, M.F. Análise morfométrica e socioambiental de uma bacia hidrográfica amazônica, Carlinda - MT. Revista Árvore, v. 36(1), p. 83-92. 2012.

USGS. SRTM Images. 2014. Disponível em: <http://dds.cr.usgs.gov/srtm/ SRTM_image_sample/docs/SRTM_Image.pdf> Acessado em: 2 out. 2014.

Valeriano, M.M. Modelo digital de variáveis geomorfométricas com dados SRTM para o território nacional: o projeto Topodata. 2005. 
Valeriano, M.M. Dados Topográficos. In: FLORENZANO, T.G. (Org). Geomorfologia, conceitos e tecnologias atuais. São Paulo: Oficina de Textos, p. 72-104. 2008.

Valeriano, M.M.; Rossetti, D.F. Topodata: Brazilian full coverage refinement of SRTM data. Applied Geography, v. 32, p. 300-309. 2012.

Vrieling, A. Satellite remote sensing for water assessment: a review. Catena, v. 65, p. 2-18, 2006.

Yang, L.; Meng, X.; Zhang, X. Srtm DEM and its aplication advances. International Journal of Remote Sensing, v. 32, p. 3875-3896, 2011.

Zonneveld, I.S. Land evaluation and land(scape)science. In: ITC textbook of phorointerpretation, v.7, 1972.

Zonneveld, I.S. Land Evaluation and Landscape Science. Enschede: The Netherlands, International Institute for Aerial Survey and earth Sciences. 1979. 
Capítulo 2: UNIDADES GEOMOROFOLÓGICAS DAS BACIAS DO RIO DAS ALMAS (GO) E RIO MARANHÃO (GO/DF) E O ESTUDO DO USO E COBERTURA DA TERRA 


\section{RESUMO}

Comumente o uso e cobertura da terra são relacionados à qualidade de solo, ao fator econômico e ao fator social, desconsiderando que a paisagem é orientada pelas categorias do relevo, e que a geomorfologia e geologia são limitantes ao uso da terra. O objetivo da pesquisa é verificar relação entre as unidades geomorfológicas ao uso e cobertura da terra. A área estudada possui $34641,95 \mathrm{~km}^{2}$ e abrange as bacias do Rio das Almas e do Rio Maranhão (GO). Foram utilizados dados SRTM para a extração das variáveis morfométricas de declividade, aspecto, curvatura máxima e mínima, usadas na composição colorida. A partir da composição colorida com as variáveis de declividade, altimetria e curvatura mínima, respectivamente nos canais RGB, foram mapeadas oito unidades geomorfológicas por meio de vetorização em tela: 1) Chapadas e Remanescentes (3,17\%), 2) Frentes de Recuo Erosivo (12,39\%), 3) Rampas de Colúvio I (4,53\%), 4) Planalto Retocado (31,57\%), 5) Depressão Interplanáltica $(18,69 \%)$, 6) Rampas de Colúvio II (11,99\%), 7) Serras (14,35\%) e 8) Depressão Dissecada (3,28\%), respectivamente as unidades e sua área em relação a área da bacia. As unidades obtidas foram comparadas aos dados de uso e cobertura da terra avaliando sua frequência da altimetria $(\mathrm{m})$ e declividade (\%), assim, as áreas mais propícias ao desenvolvimento da agricultura são as chapadas e remanescentes, as Rampas de Colúvio e as Depressões, caracterizadas como áreas planas. As pastagens e demais vegetações podem ocorrer em todas as unidades, mas geralmente estão relacionadas as áreas de relevo mais declivosas e movimentada. Conclui-se que o mapeamento geomorfológico é uma ferramenta que indica os limites naturais para o uso e ocupação da terra para ano de 2014 e o seu potencial de expansão.

Palavras-chave: mapeamento geomorfológico, RGB, bacias hidrográficas, relevo. 


\begin{abstract}
Commonly use and land cover are related to quality of soil, the economic factor and the social factor, disregarding that the landscape is driven by relief categories, and that the geomorphology and geology are limiting land use. The goal of the research is to verify the relationship between geomorphological units to use and land cover. The study area has 34,641.95 square kilometers and covers the basins of the Rio das Almas and Maranhão River (GO). SRTM data were used for extraction of morphometric variables of slope, aspect, curvature maximum and minimum, used in the colored composition. From the colorful composition with variable slope, altitude and minimum curvature respectively in the RGB channels were mapped eight geomorphological units through vectoring on screen: 1) Plateus and Remmants (3.17\%), 2) Front of Erosive Retreat (12.39\%), 3) Colluvial Ramps I (4.53\%), 4) Retouched Plateu (31.57\%), 5) Interplanlatic Deprression (18.69\%), 6) Colluvial Ramps II ( 11.99\%), 7) Ridges (14.35\%) and 8) Dissected Depression (3.28\%), respectively the units and its area over the basin area. The obtained units were compared to data use and land cover evaluating their frequency of altitude $(\mathrm{m})$ and slope $(\%)$ thus the most favorable areas for agricultural development are the plateaus and remaining, the Colluvial Ramps and Depressions , characterized as flat areas. Pastures and other vegetation can occur in all units, but usually relate the most steep and busy relief areas. We conclude that the geomorphological mapping is a tool that indicates the natural limits to the use and occupation of land for year 2014 and its expansion potential.
\end{abstract}

Key words: geomorphological mapping, RGB , watersheds, relief. 


\section{INTRODUÇÃO}

Uma classificação hierárquica da paisagem apresenta unidades que representam interações e relações locais entre rochas, clima, relevo, solo, vegetação e organismos em função do espaço e tempo (Martins et al., 2004).

O relevo possui relevância no estudo geomorfológico pois seu estudo permite a observação da organização e dinâmica da paisagem variando em escala. Para cada escala as unidades geomorfológicas do relevo refletem um padrão entre a combinação do potencial ecológico (que envolve clima, a hidrologia e a geomorfologia), a exploração biológica (fauna, flora e solo) e ação antrópica (representada pelas manifestações socioeconômicas e culturais da sociedade) (Vale, 2012).

A geomorfologia não é considerada um fator limitante ao uso e cobertura da terra nas pesquisas, estas buscam relacionar o uso e cobertura à aspectos econômicos e sociais, propriedade do solo e capacidade de uso do mesmo. Contudo, a paisagem sofre uma transformação orientada pelas categorias do relevo, em que geomorfologia e geologia são fundamentais para compreensão da dinâmica da paisagem (Carvalho et al., 2008). As feições geomorfológicas servem de locus de ocupação, proporcionando recursos à determinadas atividades e embasamento para expansão da ocupação das áreas, informações fornecidas pelas unidades geomorfológicas auxiliam no planejamento e gestão de estruturação de arranjos produtivos regionais, no acompanhamento de fluxos energéticos e na avaliação de eficiência dos sistemas do agronegócio, que requer informações detalhadas da distribuição espacial (Girão e Corrêa, 2008; Ozdogan, 2010).

Segundo Tretin et al. (2013) é possível identificar as fragilidades e potencialidades da paisagem com informações geomorfológicas refinadas, em que a análise do meio físico é subsidiada pelo estudo dos compartimentos do relevo, e contribui como base para compreensão do uso e cobertura da terra, ou seja, as informações fornecidas pelos compartimentos do relevo, as unidades geomorfológicas, são relacionadas aos outros fatores na paisagem, tais como as características sedimentológicas (Gastão e Maia, 2010; Polizel e Rossetti, 2014), com a morfodinâmica fluvial (Cavalcante \& Cunha, 2012; Merino. et al., 2013), com a geologia (Silva et al., 2007; Ibanez et al., 2014).

As bases cartográficas de estudos geomorfológicos são escassas no Estado do Goiás, especialmente para mapeamentos regionais. A falta de uma metodologia única de mapeamento e o volume reduzido de conhecimento gerado pelas universidades federais e estaduais com este fim são os fatores contribuintes para que o Projeto RADAMBRASIL seja 
a única fonte de informação regional disponível por estados durante 3 décadas (Latrubesse, 2005). É comum o uso das cartas topográficas do IBGE, produtos gerados a partir das imagens SRTM (perfis topográficos, relevos sombreados e hipsometria), mapa geológico e mapa de rede de drenagem para o mapeamento geomorfológico, contudo, a escala e continuidade das informações ed as áreas mapeadas são um limitante ao uso recorrente destas fontes.

O mapeamento geomorfológico a partir das variáveis morfométricas mostra-se como o melhor representante da dinâmica do paisagem, considerando as potencialidades dos recursos e as fragilidades ambientais naturais, gerando um produto que representa a diversidade de resistência da litologia e seu arranjo estrutural e evidencia o agente ativo de sua esculturação (Ross, 1992). Uma avaliação da evolução da paisagem e estabelecimento de uso e cobertura da terra mais próxima ao verificado em campo em escalas de 1:100.000 à 1:50.000.Este trabalho tem o objetivo de avaliar a existência das relações entre as feições do relevo e a distribuição dos usos e cobertura da terra nas bacias hidrográficas do Rio das Almas (GO) e Rio Maranhão (GO/DF) da ecorregião do Planalto Central.

\section{MATERIAL E MÉTODOS}

\section{$2.1 \quad$ Área de Estudo}

A área de estudo é constituída pelas bacias hidrográficas do Rio das Almas e Rio Maranhão no Estado do Goiás, na Ecorregião do Planalto Central. Em conjunto possuem uma área de $34.641,95 \mathrm{~km}^{2}$, o que corresponde a quase $10 \%$ de Goiás, e são o berço das nascentes das bacias hidrográficas do Tocantins - Araguaia, São Francisco e Paraná. As bacias desaguam no lago da Serra da Mesa, formando a partir daí o rio Tocantins (CTE, 2009).

As bacias hidrográficas presentam a diversidade litológica da Ecorregião do Planalto Central, abrangendo predominantemente a zona externa e zona interna da Faixa Brasília (Pimentel et al., 2011 )(figura 6). A zona externa é composta por unidades metassedimentares do mesoproterozóico - Grupo Paranoá e Canastra - e porções do embasamento ArqueanoPaleoproterozóicos (Uhlein et al., 2012; Dardenne, 1981, 2000; Faria, 1995; Guimarães, 1997). A zona interna inclui unidades alóctones dos Grupos Araxá e Serra da Mesa e as porções do embasamento (Maciço de Goiás e remanescentes de greenstone belts) (Pimentel et al., 2000). Localmente ocorre ainda complexos máfico-ultramaficos granulizados (Ferreira Filho et al., 1992) e sequências vulcanossedimentares proterozóicas (Pimentel et al., 2000). O grupo Paranoá é formado por uma sequência psamítica-pelítica a leste da Faixa Brasília, que 
transiciona para uma sequência pelítica-carbonática para oeste, mais espessa, de águas profundas (Dardenne, 1981; Schobbenhaus, 1993; Faria, 1995; Campos et al., 2013). O grupo Canastra é mais metamórfico que o Grupo Paranoá (Campos Neto, 1979; Dardenne, 1981; Faria, 1995). O Grupo Araxá é constituído por gnaisses, micaxistos, quartzitos e xistos verdes (Barbosa, 1995).

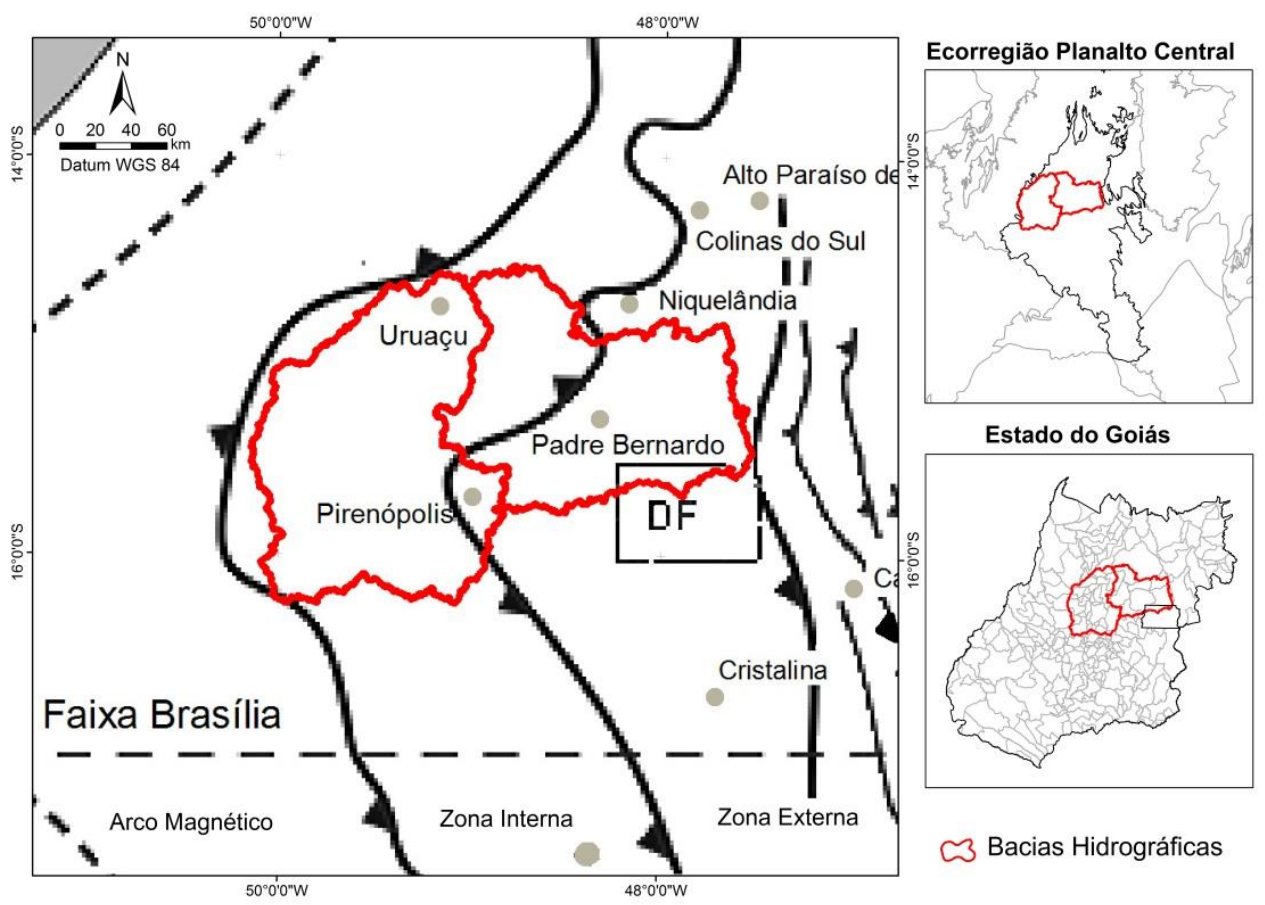

Figura 6.Localização das Bacias do Rio das Almas e do Rio Maranhão na Faixa Brasília. Fonte: Adaptação de Campos et al., 2013.

Caracterizadas pelo clima Aw, segundo Koppen, com duas estações bem definidas, uma seca e outra chuvosa, a maior parte das chuvas se concentra na região noroeste pela influência da massa de ar equatorial continental advinda da Amazônia, e na parte nordeste as chuvas são orográficas, influência da massa de ar tropical continental (Costa et al., 2012).

As bacias estão inseridas no domínio morfoestrutural dos Cinturões Móveis Neoproterozóicos, na região geomorfológica dos Planaltos e Depressões (IBGE, 2010). O domínio morfoestrutural compreende os maiores táxons da compartimentação do relevo e organizam fatos geomorfológicos numa escala regional segundo natureza das rochas e tectônica atuante, para as bacias o domínio é caracterizado por extensas áreas com planaltos, alinhamentos serranos e depressões interplanálticas (IBGE, 2009).

Quanto aos solos, os Latossolos e os Cambissolos são mais predominantes na área de estudo, que também apresenta Argissolos, Chernossolos, Gleissolos, Neossolos e Plintossolos (Pinheiro et al., 2008;). No Goiás os Latossolos são a área mais propícia para a agricultura de 
grãos, pois possuem declividades inferiores a 3\% permitindo a mecanização, são solos profundos e bem drenados (SEGPLAN, 2011).

\subsection{Aquisição das imagens do sensor SRTM}

A primeira etapa foi de aquisição dos dados da missão SRTM em que sete folhas SD-22-Z-A, SD-22-Z-B, SD-22-Z-C, SD-22-Z-D, SD-23-Y-A, SD-23Y-C, SE-22-X-A e SE22-X-B - com resolução de $3 \operatorname{arcsec}(90 \mathrm{~m})$ e sistema de coordenadas geográficas WGS 84 que foram projetados para UTM 22 Sul. Os dados foram adquiridos numa resolução compatível com a escala de 1:250.000 por meio do site Brasil em Relevo, da Embrapa http://www.relevobr.cnpm.embrapa.br. As folhas SRTM foram georreferenciadas e unidas em um mosaico. Optou-se pelo uso dos dados da Embrapa por serem comumente usados nos estudos de mapeamento geomorfológico (Hermuche i et al., 2003; Souza Lima et al., 2009; Castro et al.2010, Passo et al., 2010; Sena-Souza et al., 2013; Trentin et al., 2013), contudo, é possível usar dados disponibilizados na pela United States Geological Service - USGS (Zaloti Junior et al., 2007; Leite e Brito, 2012; Andrades Filho e Rossetti, 2012) ou ainda pelo disponibilizado pela NASA (Ibanez, Miranda e Riccomini, 2014;)

\subsection{Delimitação automática de bacias hidrográficas}

O mosaico das cenas do sensor SRTM foi usado para a delimitação automática de bacias hidrográficas seguindo a metodologia proposta por Sobrinho et al. (2010) no software ArcMap ${ }^{\circledR}$.

Na metodologia de Sobrinho et al. (2010) a correção de falhas no modelo de elevação causados por áreas mais íngremes ou montanhosas são corrigidas usando as informações dos pixels vizinhos para preencher o pixel considerado vórtice ou pico; a direção de fluxo é obtida considerando a linha de maior declividade do terreno partindo de um pixel e avaliando o valor dos seus oito pixels vizinhos; o fluxo acumulado é um parâmetro que indica o grau de contribuição do escoamento e pode ser associado ao fator de comprimento de rampa aplicado em duas dimensões, assim, cada pixel recebe um valor correspondente ao número de pixels que contribuem para que a água chegue até ele; A delimitação do exutório consiste da criação de um arquivo vetorial shapefile de pontos sinalizando o final da rede de drenagem de interesse (figura 7). 


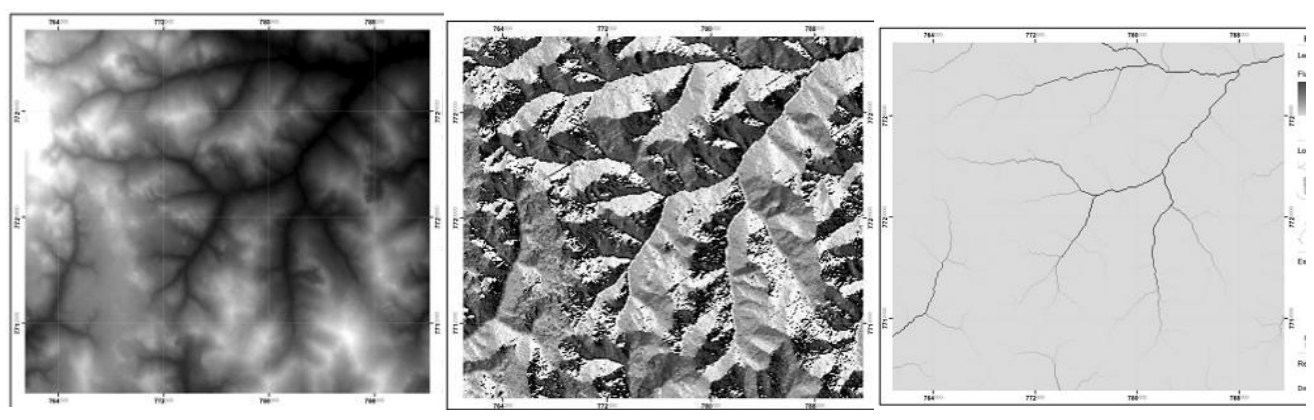

Figura 7. Em sequência visualizamos o modelo digital de elevação, a direção de fluxo e a hidrografia.

A delimitação automática das bacias é uma etapa do processamento que pode ser substituída pelo uso das ottobacias em nível de codificação 6. A diferença entre as áreas das bacias, a delimitada e a codificada por Otto, é menor que $0,5 \%$ (figura 8 ).

As ottobacias são fornecidas pelo MMA no site http://mapas.mma.gov.br/geonetwork e a codificação em níveis considera a drenagem como principal critério de classificação, é aplicada em escala continental e a codificação desconsidera os limites políticos.

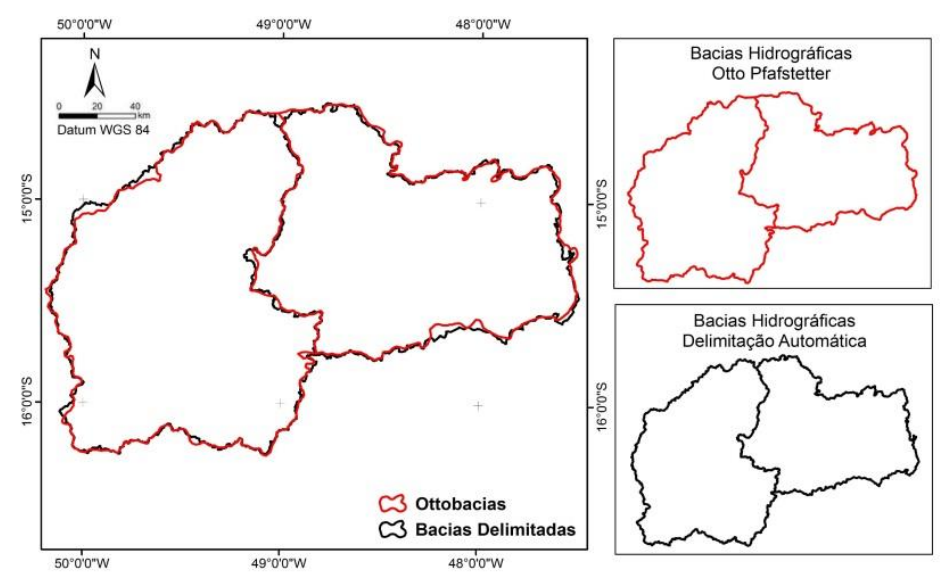

Figura 8. Comparação dos limites das bacias hidrográficas da codificação de Otto e as bacias delimitadas automaticamente a partir do MDE.

\subsection{Variáveis Morfométricas e Composição Colorida}

As variáveis morfométricas - aspecto, declividade e curvatura máxima e curvatura mínima - foram derivadas do dado de altimetria do SRTM com auxílio do ENVI®, e permitem uma avaliação de forma relativamente padronizada em diferentes ambientes a nível nacional (Bispo et al.,2010).

A variável aspecto normalmente expressa em azimute, tem propriedade de mostrar a orientação das vertentes numa medida de ângulo horizontal da direção esperada do escoamento superficial, contudo em relevos planos podem ter determinação reduzida em função do módulo de declividade que é nulo ou quase nulo. A variável declividade é o ângulo 
de inclinação da superfície local em relação ao plano normal, expressa em graus ou porcentagem, evidencia a transição entre estratos altimétricos e sugere uma percepção das curvas de nível do terreno. A variável curvatura possui a capacidade de favorecer a observação da orientação das vertentes e segmentar o relevo em unidades homogêneas (Valeriano, 2008).

Usando a técnica de composição colorida com as variáveis morfométricas, no intuito de realçar feições do relevo que facilitassem a interpretação com o máximo de informação, o dado de altimetria ocupou o canal $\mathrm{R}$, a declividade o canal $\mathrm{G}$ e as outras variáveis- aspecto e curvatura máxima e mínima - foram alternadas no canal $\mathrm{B}$, conforme realizado por outros autores (Hermuche et al., 2002; Lima et al., 2009; Castro et al., 2010; Passo et al., 2010; Sena-Souza et al., 2013). A técnica de composição colorida destina cores às variáveis morfométricas permitindo que haja um realce visual das sutis variações dos níveis de cinza das imagens que passam despercebidas ao observador, mas que podem representar diferenças num alvo que parece homogêneo. A combinação das variáveis do sensor com as cores azul, verde e vermelha em uma imagem colorida aumentam a percepção do interprete às informações dos dados, propiciando maior qualidade de extração de informações (Florenzano, 2008; Meneses et al.,2012).

\subsection{Delimitação das Unidades Geomorfológicas e Análise de Uso e Cobertura da terra}

A delimitação das unidades geomorfológicas foi realizada por vetorização digital em tela numa escala de 1:100.000, em que os padrões de cor, textura e forma foram separados conforme a intensidade da cor, a ocorrência da cor associada a textura e a forma, e a localização da cor em relação as demais cores, seguindo procedimento de Sena- Souza (2013), também usado para a denominação de cada unidade geomorfológica (tabela 2). O mapeamento geomorfológico realizado obedece a hierarquia da classificação proposta pelo IBGE (2009), definindo-se o domínio morfoestrutural, a região geomorfológica e a unidade geomorfológica. 
Tabela 2. Chave de identificação das unidades Geomorfológicas. Fonte: Adaptação de Sena-Souza (2013).

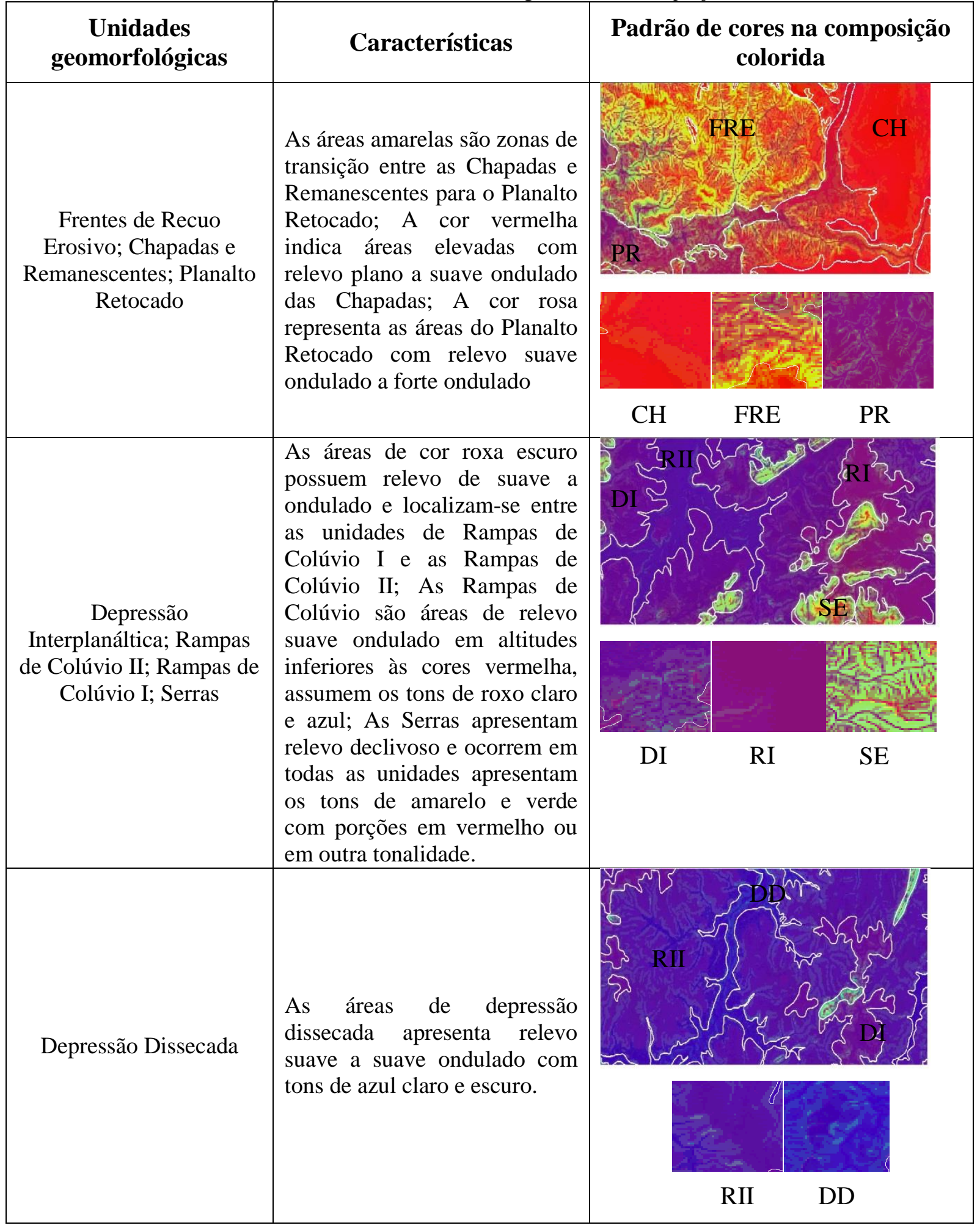

As unidades geomorfológicas servem como base para análise da distribuição do uso e cobertura da terra, por isso a frequência da altitude e declividade das unidades são comparadas as frequências da altitude e declividade do uso e cobertura da terra (agricultura, pastagem, floresta, reflorestamento, cerrado e área urbana) para pesquisar a relação entre as 
características topográficas e a espacialização da cobertura vegetal. Importante ressaltar que a vegetação natural (cerrado) não é subdivida em fitofisionomias descritas por Ribeiro e Walter (2008), sendo uma limitação a análise da distribuição dessas coberturas vegetais nas unidades geomorfológicas.

Os dados de uso e cobertura da terra foram adquiridos numa escalda de 1:250.000 do ano de 2014 pelo site do Sistema Estadual de Geoinformação do Goiás: http://www.sieg.go.gov.br/. Os dados em formato shapefile estão dispostos na categoria de macrozoneamento agroecológico e econômico do Estado do Goiás como um dos produtos, como fontes estão os órgãos da Secretaria do Meio Ambiente e dos Recursos Hídricos, a Secretaria de Estado e Infraestrutura, Cidades e Assuntos Metropolitanos e a Secretaria da Agricultura e Pecuária.

\subsection{Validação do mapeamento geomorfológico}

A validação em campo seguiu um roteiro de percurso contemplando todas as unidades geomorfológicas, avaliando as informações obtidas no mapeamento das unidades geomorfológicas e as características da paisagem quanto ao relevo e uso e cobertura da terra. Ao todo foram verificados 74 pontos de controle com o uso de um GPS (figura 9) e o relatório está no Anexo A

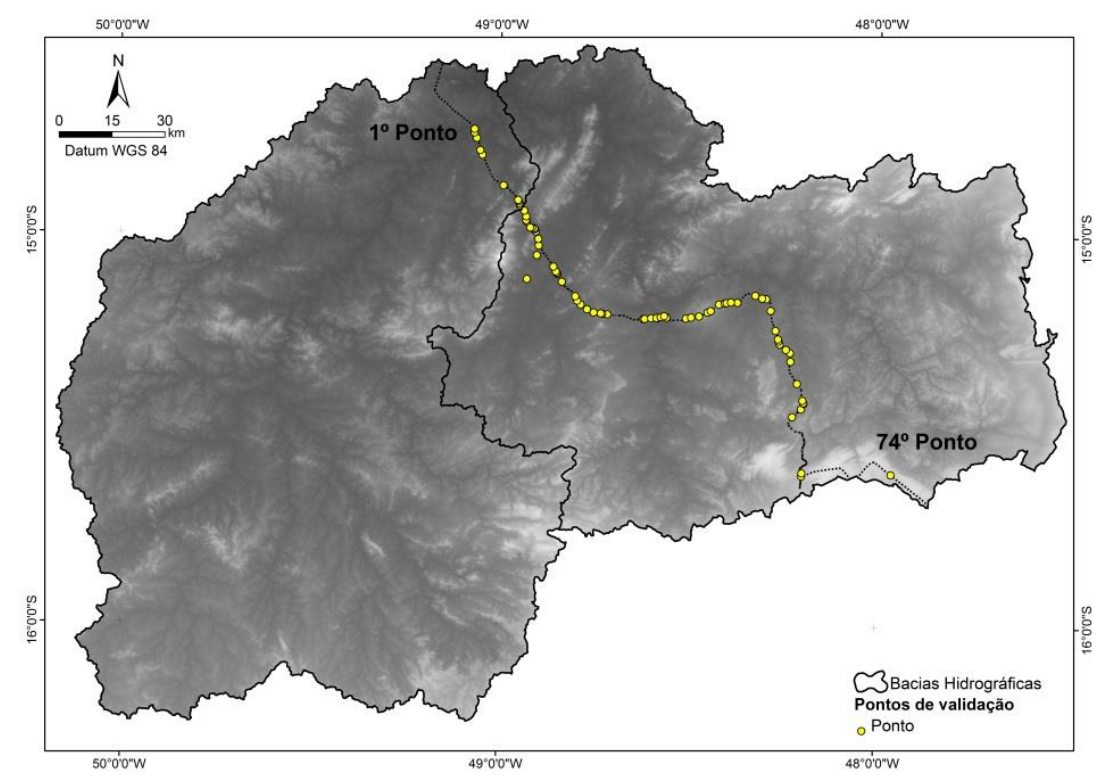

Figura 9. Trajeto de validação das unidades geomorfológicas das bacias Rio das Almas (GO) e Rio Maranhão(GO/DF). 


\section{RESULTADOS E DISCUSSÃO}

A delimitação automática de bacia hidrográfica resultou em duas bacias, a do Rio das Almas (GO) e a do Rio Maranhão (GO/DF), com 18949,05 km² e 15692,90 km², respectivamente (figura 10).

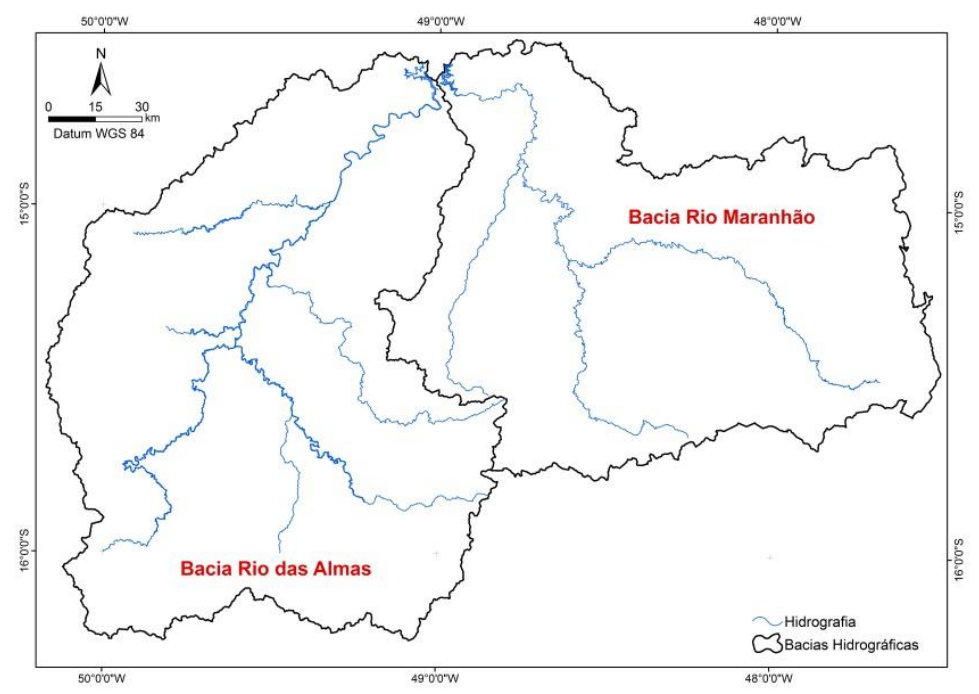

Figura 10. Bacias Hidrográficas.

A avaliação de frequência das variáveis morfométricas de altimetria e declividade das bacias do Rio das Almas (GO) e Rio Maranhão (GO/DF) indicam que a bacia do Rio Maranhão possui mais áreas com altitudes elevadas e mais áreas declivosas que a bacia do Rio das Almas, 420 a $1350 \mathrm{~m}$ e de 0 a $57 \%$ de declividade, e $420 \mathrm{~m}$ a $1150 \mathrm{~m}$ e de 0 a $47 \%$, respectivamente (figura 11).

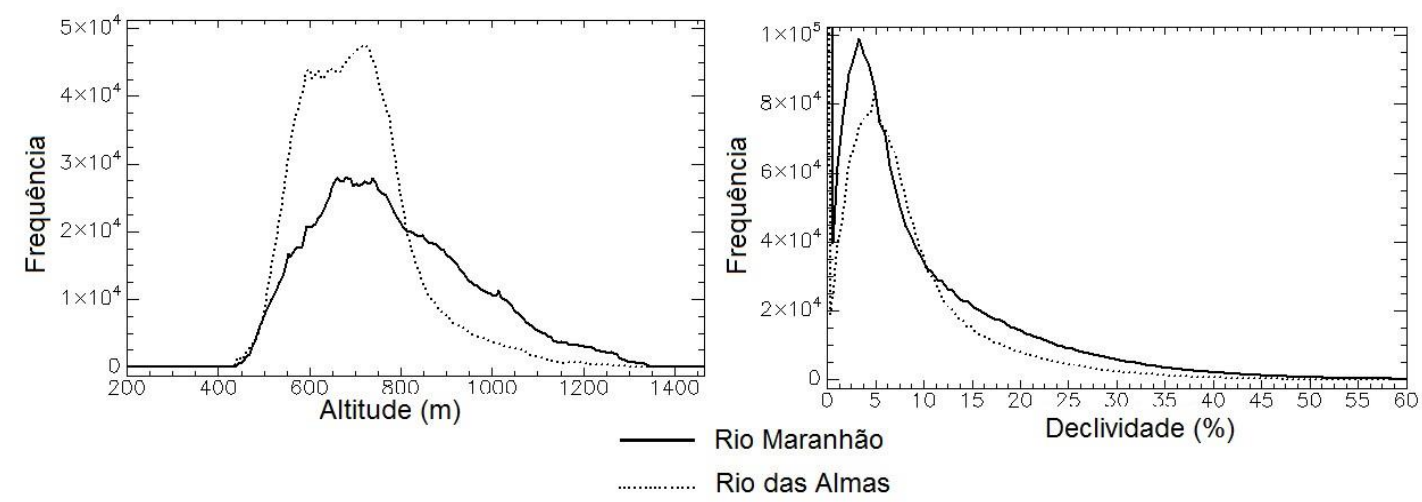

Figura 11. Frequência da altimetria e da declividade nas bacias do Rio das Almas e Rio Maranhão.

A análise de uso e cobertura mostra que a agricultura e pastagem estão inseridas preferencialmente na bacia do Rio das Almas (GO), enquanto que a vegetação de cerrado e pastagem estão preferencialmente inseridas na bacia do Rio Maranhão (figura 12), tal configuração da paisagem é resultante da dinâmica de ocupação do território goiano que 
segue o padrão nacional indo do leste para o oeste e do sul para o norte (Silva, 1982; Estevam, 1998). Após o fim da mineração o território goiano passou a ser ocupado pela pecuária, nas regiões sul e sudoeste as áreas abandonadas com topografia plana foram ocupadas por núcleos familiares (Martins, 1997). Estas áreas são resultado de uma cobertura sedimentar, solos com boa fertilidade natural e áreas de cerrado aberto (pastagem natural). Nas décadas de 40 e 50 do século XX o Goiás, particularmente, sofreu profundas transformações em decorrência das políticas de interiorização do desenvolvimento e integração nacional (Anacleto e Miziara, 2006).

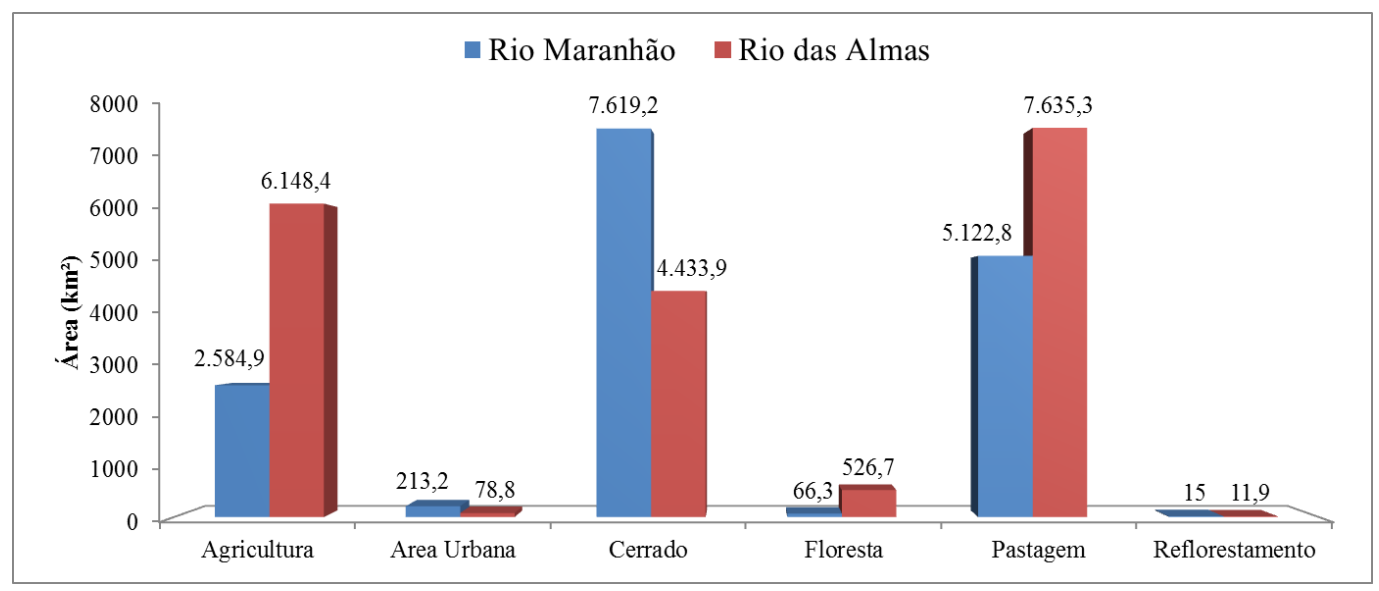

Figura 12. Distribuição do Uso e Cobertura da terra nas Bacias do Rio das Almas (GO) e Rio Maranhão (GO/DF).

A composição RGB com melhor resultado de caracterização do relevo, com maior visualização de padrões do relevo foi a de altimetria $(\mathrm{R})$, declividade $(\mathrm{G})$ e curvatura mínima (G). O mesmo foi encontrado pelos autores Lima et al. (2009), Castro et al. (2010) e SenaSouza (2013) para a composição colorida (figura 13). 


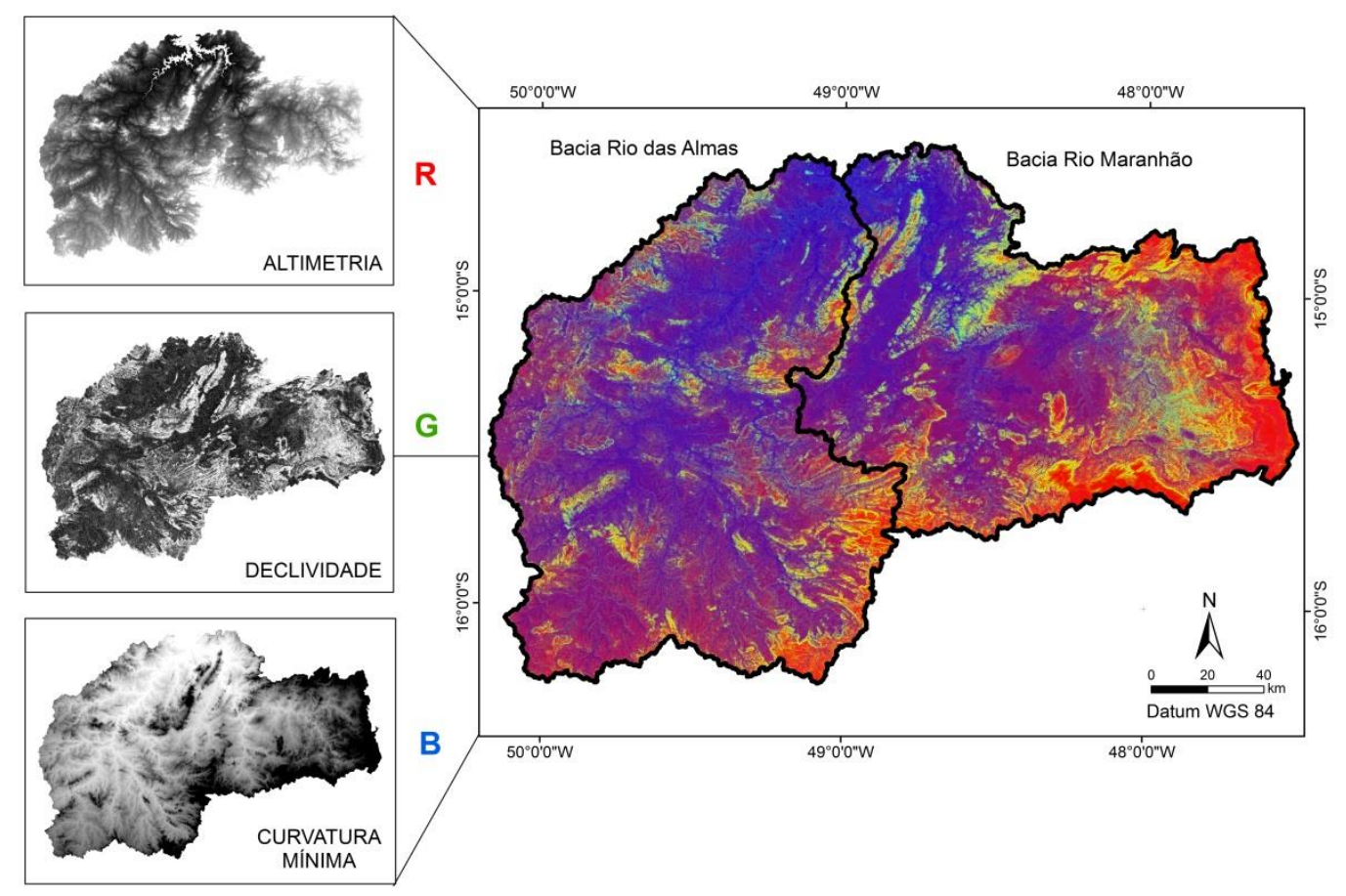

Figura 13 Planos de informação da composição colorida com as variáveis Altimetria (m), Declividade (\%) e Curvatura Mínima, nos canais RGB, respectivamente.

O mapeamento geomorfológico obteve oito unidades geomorfológicas, denominadas como Chapadas e Remanescentes, Frentes de Recuo Erosivo, Rampas de Colúvio I, Planalto Retocado, Depressão Interplanáltica, Serras, Rampas de Colúvio II e Depressão Dissecada (figura 14 e 15), suas características estão apresentadas na tabela 3. As unidades geomorfológicas foram classificadas quanto ao processo morfogenético em erosivo ou estável e sistema cárstico. No Estado do Goiás mais de $97 \%$ da superfície é caracterizada com processo erosivo e em apenas $1,7 \%$ predomina o deposicional, sendo a planície aluvial do Araguaia o mais expressivo deles (Latrubesse, 2005). 


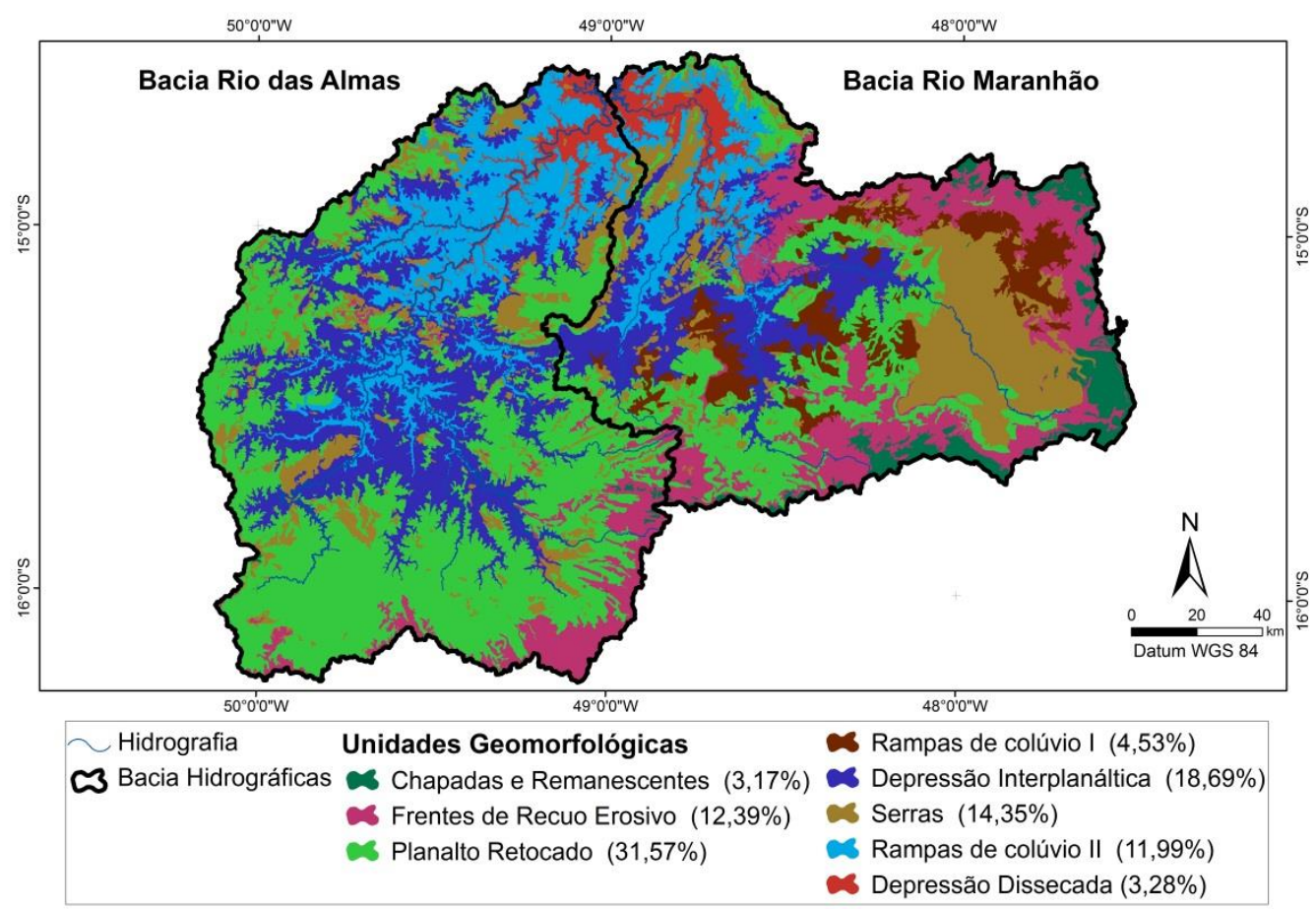

Figura 14. Unidades Geomorfológicas das bacias do Rio das Almas e Rio Maranhão no Goiás.

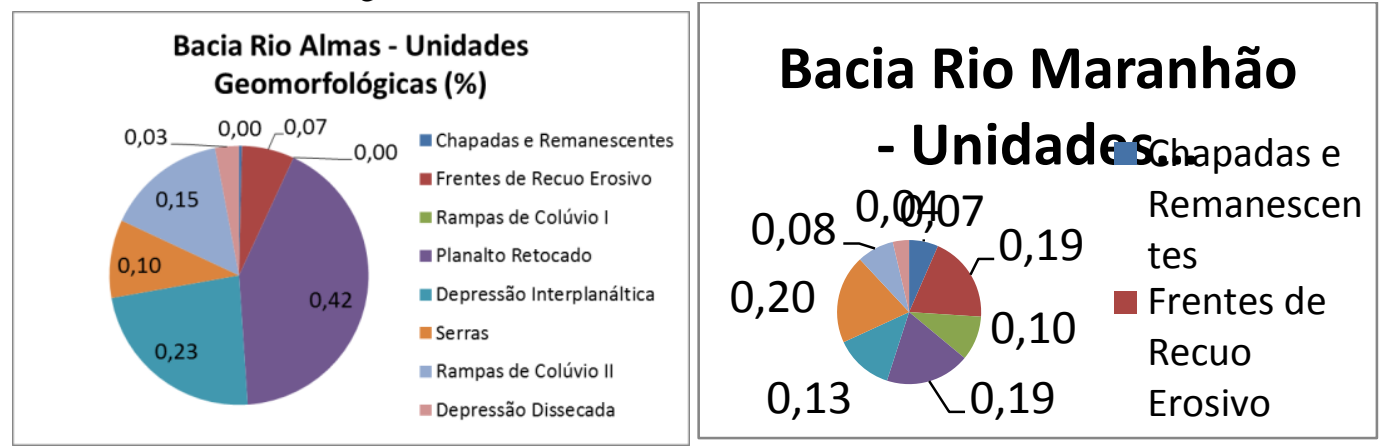

Figura 15. Gráfico de área percentual das unidades geomorfológicas das bacias do Rio das Almas (GO) e Rio Maranhão (GO/DF).

Tabela 3. Características das unidades geomorfológicas das bacias do Rio das Almas (GO) e Rio Maranhão (GO/DF).

\begin{tabular}{|c|c|}
\hline Domínio Morfoestrutural: Cinturões & Região Geomorfológica: Planaltos e \\
Móveis Neoproterozóicos (IBGE, 2010). & Depressões (IBGE, 2010). \\
\hline
\end{tabular}

\begin{tabular}{|c|c|}
\hline $\begin{array}{c}\text { Unidades } \\
\text { geomorfológicas }\end{array}$ & $\begin{array}{r}\text { Características das unidades geomorfológicas das bacias do Rio das } \\
\text { Almas (G) e Rio Maranhão (GO/DF). }\end{array}$ \\
\hline $\begin{array}{c}\text { Chapadas e } \\
\text { Remanescentes }\end{array}$ & $\begin{array}{c}\text { Estão inseridos nas altitudes de } 800 \text { a } 1370 \text { m em declividade média de 17,3\%, } \\
\text { caracterizadas por relevo plano e ondulado (Ramalho Filho e Beek, 1995). Os } \\
\text { Latossolos são os solos predominantes. Estas condições caracterizam um } \\
\text { processo morfogenético estável; }\end{array}$ \\
\hline & \begin{tabular}{c} 
parion \\
\hline
\end{tabular} \\
\hline
\end{tabular}




\begin{tabular}{|c|c|}
\hline 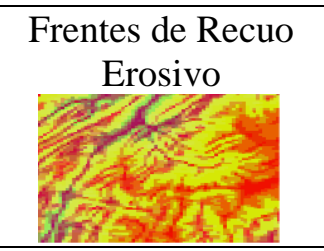 & $\begin{array}{c}\text { Em altitudes de } 570 \text { a } 1340 \text { m de altitude e declividade média de até } 43,0 \% \text {. Os } \\
\text { Cambissolos e Neossolos Litólicos são os solos predominantes. O relevo varia } \\
\text { de forte ondulado a montanhoso (Ramalho Filho e Beek, 1995). O processo } \\
\text { morfogenético erosivo predomina nestas condições. }\end{array}$ \\
\hline $\begin{array}{c}\text { Rampas de Colúvio } \\
\text { I }\end{array}$ & $\begin{array}{l}\text { Inserida em altitudes de } 670 \text { a } 870 \text { m e com declividade média de } 21,4 \% \text {. O } \\
\text { relevo varia de suave a forte ondulado (Ramalho Filho e Beek, 1995). Ocorre } \\
\text { entre as Frentes de Recuo Erosivo e a Depressão Interplanáltica. O processo } \\
\text { morfogenético deposicional é o prevalente, sendo os Latossolos as classes de } \\
\text { solos dominantes. }\end{array}$ \\
\hline & $\begin{array}{c}500 \text { a } 700 \text { m de altitude e declividade média de } 24,0 \% \text {. Esta unidade apresenta } \\
\text { relevo suave a forte ondulado (Ramalho Filho e Beek, 1995). O processo } \\
\text { morfogenético deposicional e erosivo são predominantes, encaixada entre a } \\
\text { depressão dissecada e a depressão interplanáltica. Os Latossolos predominam } \\
\text { na unidade. }\end{array}$ \\
\hline & $\begin{array}{l}\text { Unidades que ocorrem desde } 520 \text { a } 1180 \mathrm{~m} \text { de altitude, com declividade média } \\
\text { de } 46,87 \% \text {; processo morfogenético erosivo, Cambissolos predominam na } \\
\text { unidade. Relevo caracterizado de forte ondulado a montanhoso (Ramalho Filho } \\
\text { e Beek, 1995). }\end{array}$ \\
\hline $\mathrm{Pla}$ & $\begin{array}{l}\text { Entre } 580 \text { a } 1020 \text { m de altitude e declividade média de } 25,3 \% \text {. O relevo varia } \\
\text { de suave ondulado a forte ondulado (Ramalho Filho e Beek, 1995). Esta } \\
\text { unidade é resultado de um processo de dissecação da unidade de Rampas de } \\
\text { Colúvio I. Os processos morfogenéticos cárstico e erosivo ocorrem nestas } \\
\text { condições. As principais classes de solos são Latossolos e Cambissolos. }\end{array}$ \\
\hline $\begin{array}{r}\mathrm{De} \\
\text { Inter }\end{array}$ & $\begin{array}{l}\text { Ocorre nas altitudes de } 540 \text { e } 740 \mathrm{~m} \text { de altitude e declividade média de } 23,2 \% \text {. } \\
\text { O relevo varia entre suave a forte ondulado (Ramalho Filho e Beek, 1995). O } \\
\text { processo morfogenético erosivo é o mais importante, com elevado alto grau de } \\
\text { dissecação, encaixada entre as Rampas de Colúvio II e o Planalto Retocado. As } \\
\text { classes de solo Latossolos e Cambissolos são as predominantes }\end{array}$ \\
\hline $\begin{array}{l}\text { Depressão } \\
\text { Dissecada }\end{array}$ & $\begin{array}{c}\text { Entre } 440 \text { a } 540 \mathrm{~m} \text { de altitude e declividade média de } 13,1 \% \text {. O relevo varia de } \\
\text { suave a ondulado (Ramalho Filho e Beek, 1995). O processo morfogenético } \\
\text { predominante é o deposicional, com Latossolos, Cambissolos e Neossolos } \\
\text { Flúvicos predominantes na unidade. }\end{array}$ \\
\hline
\end{tabular}

A altitude e a declividade têm papel fundamental na compreensão da distribuição da cobertura vegetal e da ocupação das áreas (Couto Júnior, 2010; Roverdder et al., 2014). A análise da frequência altimétrica das unidades geomorfológicas (figura 16) mostra que as unidades ocorrem em intervalos de altitude e médias de declividade distintas. A característica de altitude relaciona-se a distribuição altitudinal do solo e ao clima, condicionando diferentes padrões de vegetação na paisagem; a declividade possui ação direta sobre o equilíbrio entre a infiltração de água no solo e o escoamento superficial, e controla a intensidade dos fluxos de matéria e insolação (Bispo et al., 2009). 

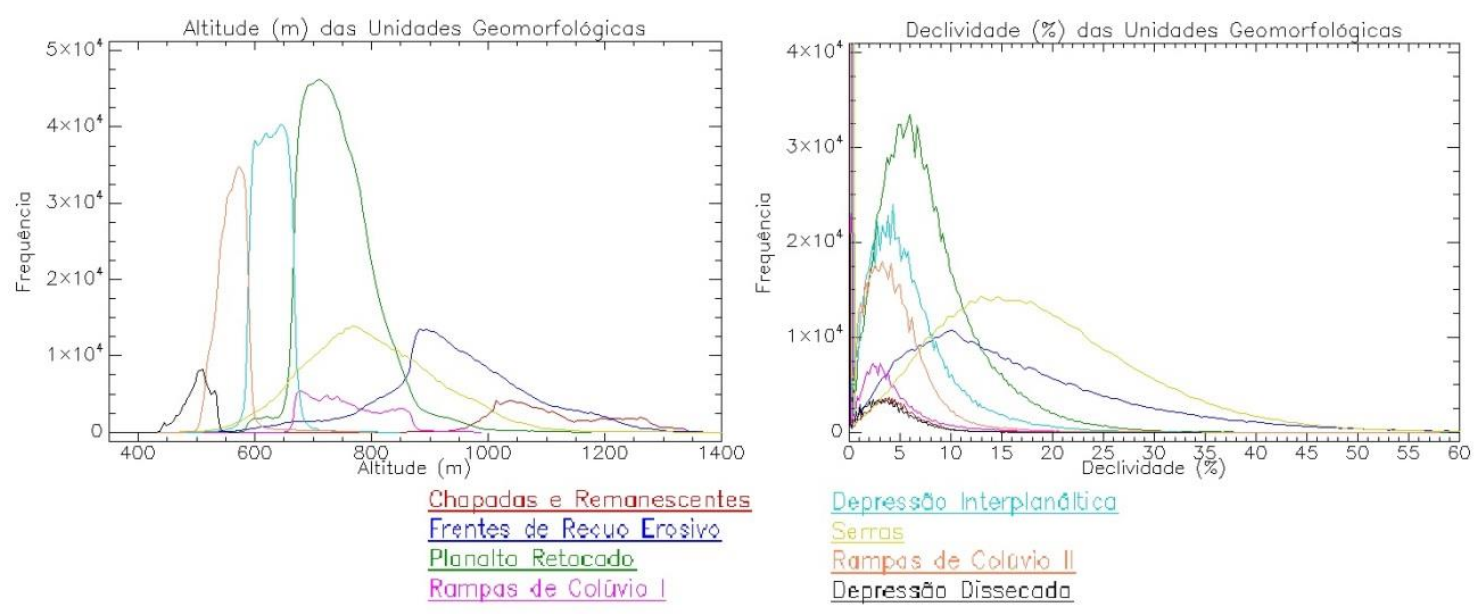

Figura 16. Unidades geomorfológicas e suas frequências altimétricas e de declividade.

O uso e cobertura da terra apresenta distribuição distinta entre as bacias (figura 12 e 17), evidenciando a importância da topografia local para a caracterização da paisagem no que tange ao estabelecimento, ocorrência e diversidade de espécies vegetais, e permitindo o estudo da dinâmica e de sua auto-organização (Carvalho et al., 2008; Bispo et al., 2009; 2010), por isso, apesar da possibilidade de todos os usos ocorrerem dentro da mesma unidade geomorfológica avaliando as características de declividade e altitude é possível verificar o potencial uso e cobertura vegetal específico para cada unidade Segundo Nascimento (1991) a estrutura geológica possui relação estreita com a disposição dos cursos d'água no Estado do Goiás, em que as rochas que constituem a paisagem possibilitam maior ou menor escoamento superficial em função de sua porosidade, tal característica implica na modelagem do modelado terrestre pela ação morfogenética dos rios, configurando o controle estrutural da paisagem, contudo, a observação da distribuição do uso e cobertura da terra mostra que esta não está em função da distribuição litológica ou de solos das bacias (figura 18 e 19) e que as unidades geomorfológicas estão mais próximas da distribuição de uso e cobertura da terra na área de estudo. 


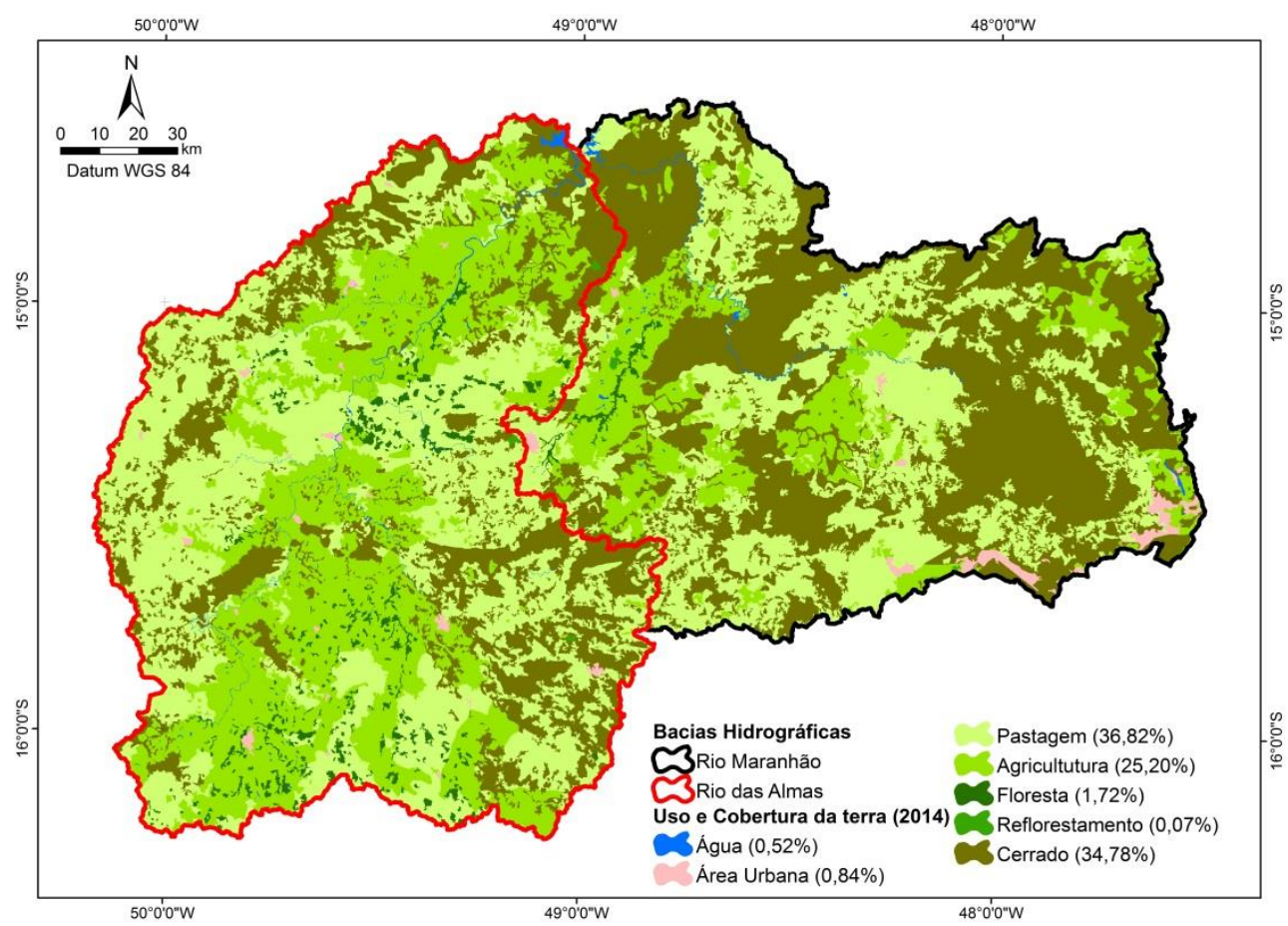

Figura 17. Distribuição do Uso e Cobertura da terra nas bacias do Rio das Almas (GO) e Rio Maranhão (GO/DF).

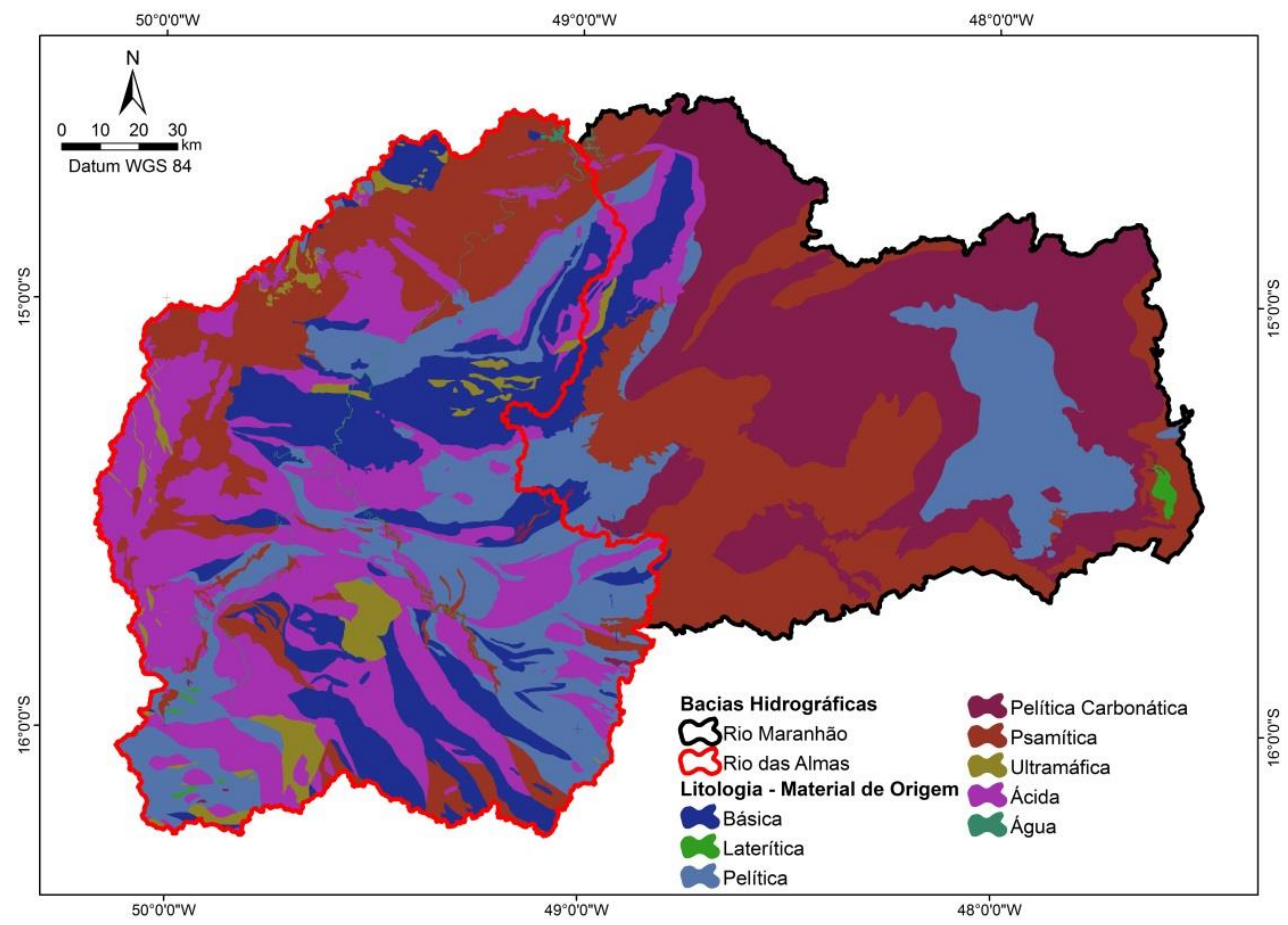

Figura 18. Litologia das Bacias Hidrográficas do Rio das Almas (GO) e Rio Maranhão (GO/DF). 


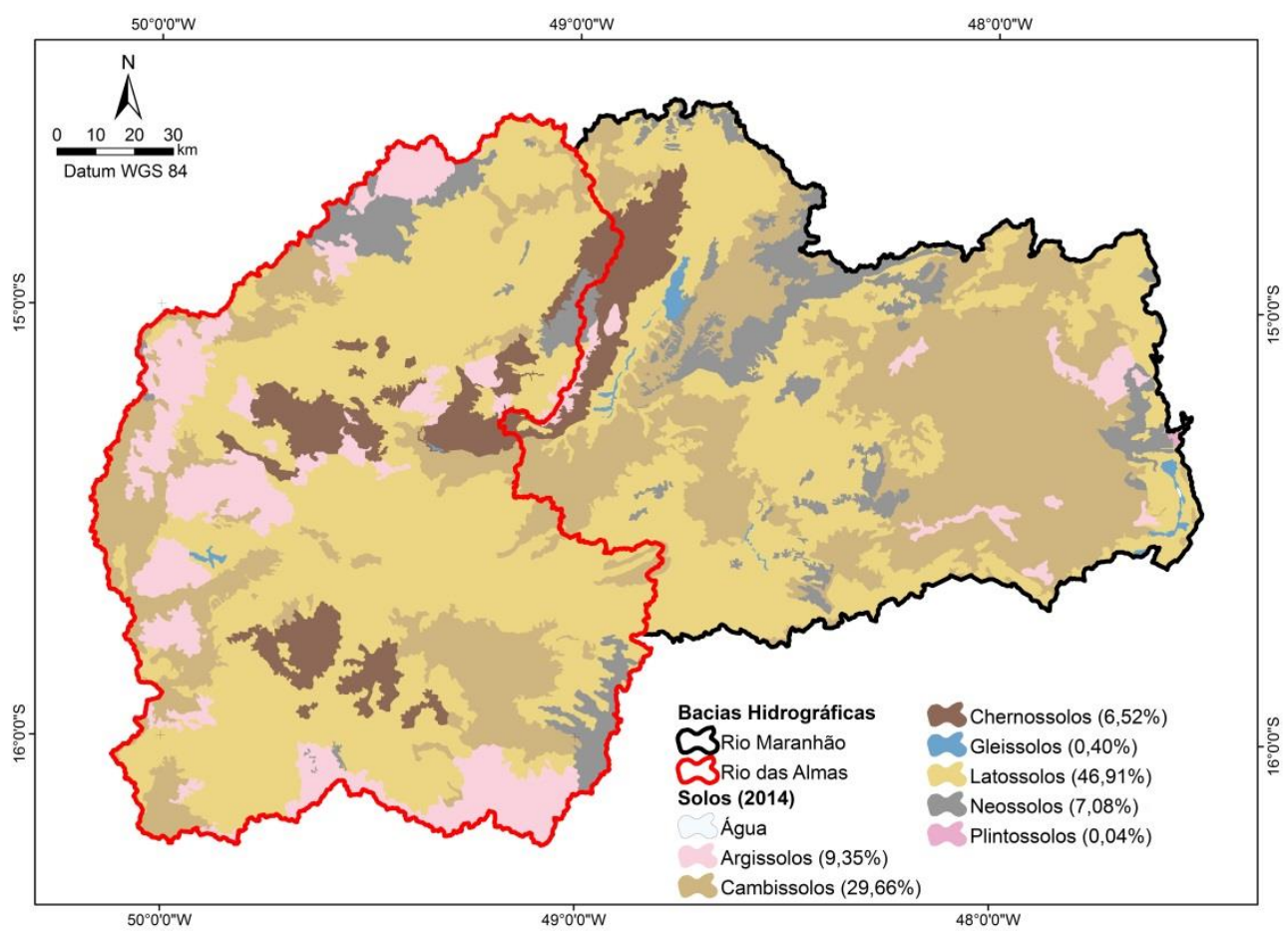

Figura 19. Ocorrência dos solos nas bacias do Rio das Almas e Rio Maranhão. Fonte: SIEG : MacroZEE - Meio físico, 2014.

A interferência na evolução natural dos componentes da paisagem por diferentes formas de uso e ocupação do solo pela sociedade causa impactos na capacidade produtiva e na sustentabilidade no meio físico e biótico (Romão e Souza, 2011; Andrade, Reis e Reis, 2015), assim, para que haja um planejamento e ordenamento da ocupação territorial é necessário considerar tanto as condições topográficas locais quanto as condições propícias aos usos. Logo, por meio da análise da altimetria e da declividade dos usos e cobertura da terra a agricultura ocorre entre as altitudes 470 a 1300 m e declividades de 0 a 23\%, a área urbana ocorre pontualmente entre as altitudes de 550 a 1250 e 0 a $10 \%$ de declividade, a pastagem ocorre entre 450 a $1300 \mathrm{~m}$ de altitude e declividades de 0 a $42 \%$, a floresta ocorre entre 500 a $1000 \mathrm{~m}$ de altitude e declividades de 0 a $15 \%$, e o cerrado ocorre em altitudes de 440 a $1300 \mathrm{~m}$ e declividades de 0 a 54\% (figura 20). A avaliação da frequência de altimetria dos usos revela que eles compartilham os intervalos altimétricos, mas a avaliação de frequência de declividade dos usos mostra que apesar de compartilharem as declividades de 0 a $10 \%$ após este ponto alcançam declividades de até $53 \%$. A análise quantitativa de área ocupada pelos usos e cobertura nas unidades geomorfológicas mostra que a agricultura é predominante nas Chapadas e Remanescentes, Depressão Interplanáltica e Rampas de Colúvio I e II; a pastagem é predominante no Planalto Retocado e Depressão Interplanática, o Cerrado é predominante nas Frentes de Recuo Erosivo, Depressão Dissecada e nas Serras (tabela 4). 

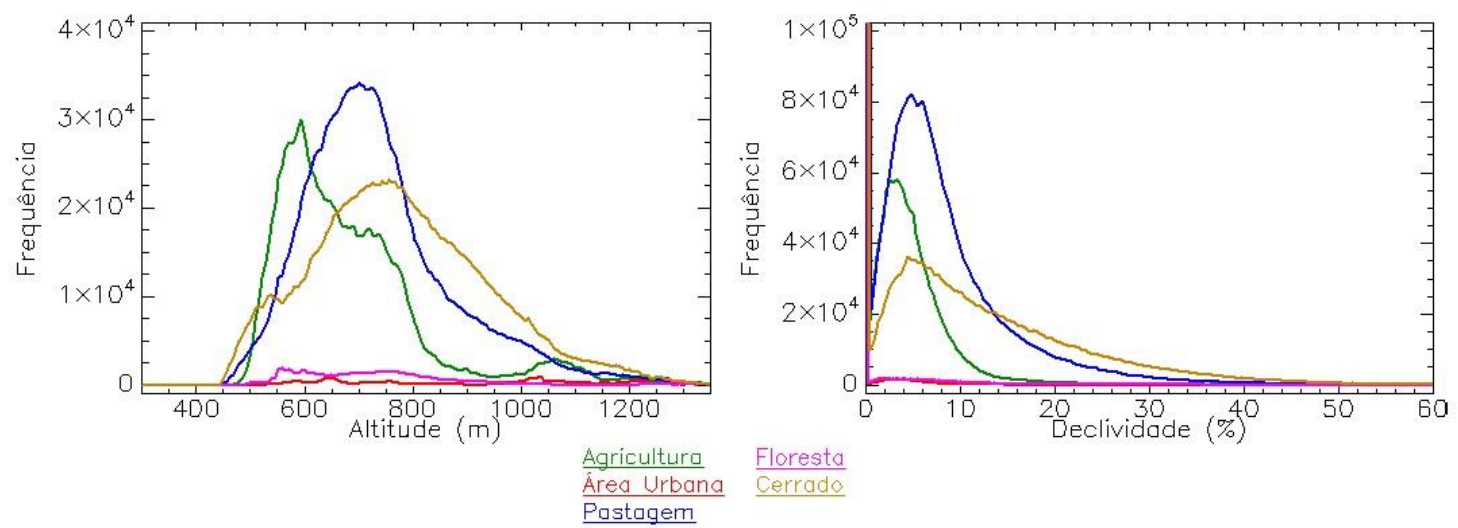

Figura 20. Frequência da altimetria e da declividade no uso e cobertura da terra.

Tabela 4.das áreas percentual do uso e cobertura da terra nas unidades geomorfológicas. Fonte: Uso e Cobertura da terra, MacroZEE, 2014.

\begin{tabular}{|c|c|c|c|c|c|c|}
\hline $\begin{array}{c}\text { Unidades } \\
\text { Geomorfológicas }\end{array}$ & $\begin{array}{c}\text { Agricultura } \\
(\%)\end{array}$ & $\begin{array}{c}\text { Área } \\
\text { Urbana } \\
(\%)\end{array}$ & $\begin{array}{c}\text { Cerrado } \\
(\%)\end{array}$ & $\begin{array}{c}\text { Floresta } \\
(\%)\end{array}$ & $\begin{array}{c}\text { Pastagem } \\
(\%)\end{array}$ & $\begin{array}{c}\text { Reflorestamento } \\
(\%)\end{array}$ \\
\hline $\begin{array}{c}\text { Chapadas e } \\
\text { Remanescentes }\end{array}$ & 36,47 & 12,74 & 30,75 & 0,17 & 18,87 & 0,36 \\
\hline $\begin{array}{c}\text { Frentes de Recuo } \\
\text { Erosivo }\end{array}$ & 7,48 & 0,85 & 57,83 & 1,17 & 32,56 & 0,02 \\
\hline Rampas de colúvio I & 39,45 & 0,48 & 25,50 & 34,53 & -- & -- \\
\hline Planalto Retocado & 22,88 & 0,34 & 24,11 & 2,31 & 50,23 & 0,04 \\
\hline $\begin{array}{c}\text { Depressão } \\
\text { Interplanáltica }\end{array}$ & 37,88 & 0,80 & 19,06 & 1,73 & 40,00 & -- \\
\hline Serras & 2,83 & 0,01 & 71,94 & 1,49 & 23,71 & -- \\
\hline Rampas de colúvio II & 49,78 & 0,43 & 20,93 & 2,35 & 25,27 & 0,19 \\
\hline Depressão Dissecada & 19,91 & 0,03 & 45,20 & 0,70 & 26,14 & -- \\
\hline
\end{tabular}

Segundo Ross (1994) o uso da terra é condizente com a fragilidade do ambiente considerando a sua declividade, à fragilidade dos solos que o constituem e o tipo de uso e cobertura. A declividade é divida em 1) áreas com fragilidade muito fraca possuem declividades menores que $6 \%$; 2) fragilidade fraca entre $6-12 ; 3$ ) fragilidade média entre 12 - 20\%; 4) fragilidade forte entre $20-30 \%$; 5) com fragilidade muito forte em declividades maiores que $30 \%$, dessa maneira as áreas mais frágeis são as Serras e as Frentes de Recuo Erosivo com 46,87\% e 42,96\% de declividade média, respectivamente.

Os solos são divididos em fragilidade muito fraca, fraca, média, forte e muito forte, os Latossolos ocupam as classes de fragilidade muito fraca, fraca e média, os Cambissolos a classe de fragilidade forte, e os Litólicos e Areias Quartzosas com fragilidade muito forte (Ross, 1994), neste quesito as unidades mais frágeis por possuírem maior área de Cambissolos são as Frentes de Recuo Erosivo e as Serras, as que possuem fragilidade de muito fraca à média são as Chapadas e Remanescentes, as Rampas de Colúvio, as Depressões e o Planalto Retocado (tabela 5). 
Tabela 5. Distribuição dos solos nas unidades geomorfológicas. Área percentual.

\begin{tabular}{|c|c|c|c|c|c|c|c|}
\hline $\begin{array}{c}\text { Unidades } \\
\text { Geomorfológicas }\end{array}$ & $\begin{array}{c}\text { Argissol. } \\
(\%)\end{array}$ & $\begin{array}{c}\text { Cambissol. } \\
(\%)\end{array}$ & $\begin{array}{c}\text { Chernossol. } \\
(\%)\end{array}$ & $\begin{array}{c}\text { Gleissol. } \\
(\%)\end{array}$ & $\begin{array}{c}\text { Latossol. } \\
(\%)\end{array}$ & $\begin{array}{c}\text { Neossol. } \\
(\%)\end{array}$ & $\begin{array}{c}\text { Plintossol. } \\
(\%)\end{array}$ \\
\hline $\begin{array}{c}\text { Chapadas e } \\
\text { Remanescentes }\end{array}$ & 0,01 & 0,40 & -- & 0,08 & 2,33 & 0,16 & 0,04 \\
\hline $\begin{array}{c}\text { Frentes de Recuo } \\
\text { Erosivo }\end{array}$ & 1,77 & 3,89 & 0,07 & 0,03 & 3,78 & 2,96 & 0,00 \\
\hline Rampas de Colúvio I & 0,24 & 2,00 & 0,00 & -- & 2,13 & 0,16 & -- \\
\hline Planalto Retocado & 3,70 & 8,06 & 1,87 & 0,00 & 16,67 & 1,11 & -- \\
\hline $\begin{array}{c}\text { Depressão } \\
\text { Interplanáltica }\end{array}$ & 2,27 & 4,92 & 1,60 & 0,08 & 9,32 & 0,50 & -- \\
\hline Serras & 0,76 & 8,06 & 2,05 & 0,00 & 1,62 & 1,87 & -- \\
\hline $\begin{array}{c}\text { Rampas de Colúvio } \\
\text { II }\end{array}$ & 0,57 & 1,42 & 0,70 & 0,20 & 8,81 & 0,29 & -- \\
\hline Depressão Dissecada & 0,00 & 0,90 & 0,09 & 0,02 & 2,26 & 0,01 & -- \\
\hline
\end{tabular}

A cobertura vegetal e o tipo de manejo são fatores base para a conservação ambiental e que Ross (1994) classifica por grau de proteção aos solos, em que as áreas de florestas e matas nativas são áreas de grau muito alto de proteção as formações arbustivas naturais densas com grau alto; as pastagens cultivadas de baixo pisoteio e cultivos de ciclo longo como grau médio; os cultivos de ciclos longos de baixa densidade ou ciclo curto com grau baixo; e as áreas desmatadas ou queimadas recentemente, solo exposto e cultivos curtos sem práticas conservacionistas como grau muito baixo ou nulo. Assim sendo, as unidades de maior fragilidade ambiental por declividade e solos devem manter cobertura vegetal considerada como muito alto e alto grau protetivo.

A avaliação da distribuição do uso e cobertura da terra nas unidades geomorfológicas apresenta uma assinatura de uso, que semelhante a uma assinatura espectral mostra o comportamento do uso dentro das unidades geomorfológicas na bacia do Rio das Almas e na bacia do Rio Maranhão. Na bacia do Rio das Almas a agricultura possui o máximo de área ocupada nas unidades de Planalto Retocado e Depressão Interplanáltica; o cerrado tem máximo de ocupação nas unidades de Frentes de Recuo Erosivo, Planalto Retocado, Serras e Depressão Dissecada; a pastagem tem máximo de ocupação nas unidades de Frentes de Recuo Erosivo, Planalto Retocado e Depressão Interplanáltica (figura 21). A unidade de Chapadas e Remanescentes e as Rampas de Colúvio I possuem as menores áreas da bacia do Rio das Almas (figura 14) e por isso visualmente parecem inexpressivas quando comparadas às demais unidades. 


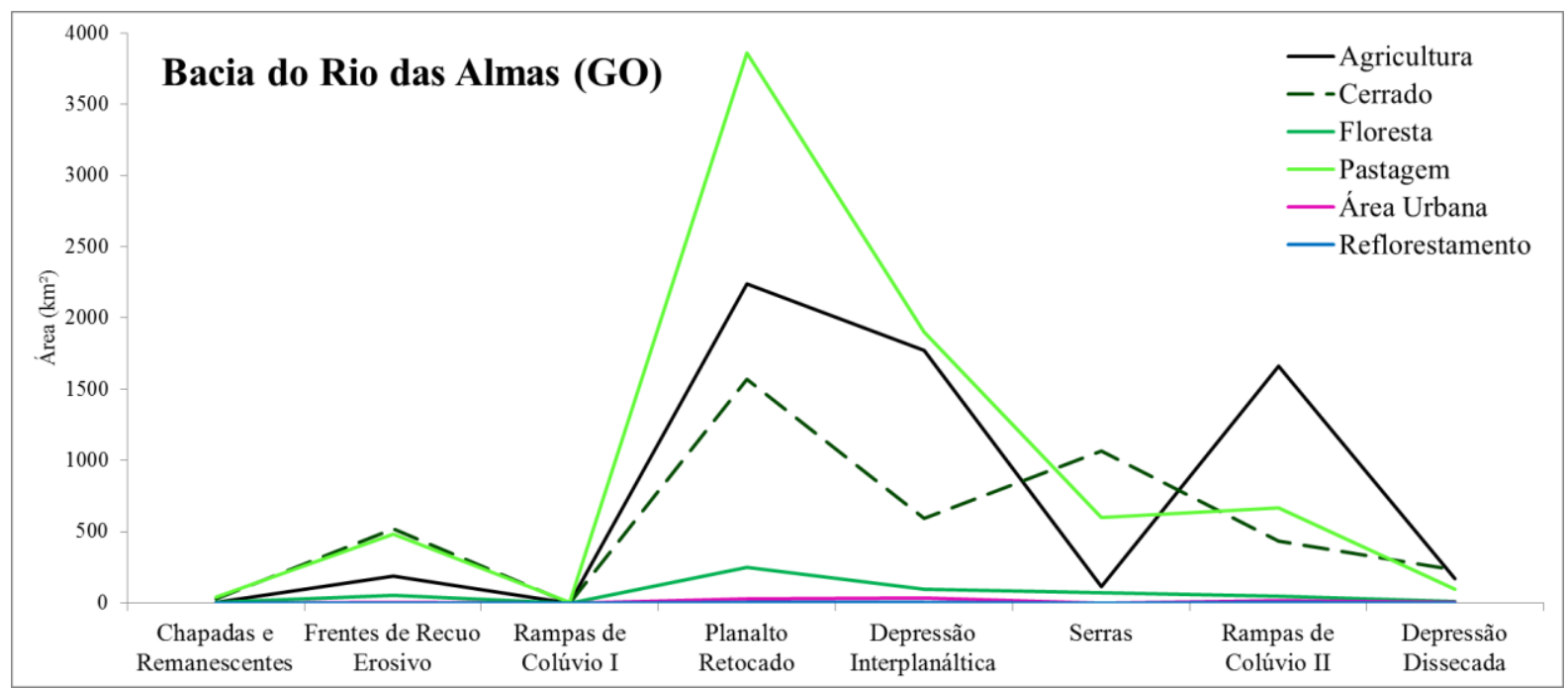

Figura 21 Assinatura de Uso e Cobertura da terra na bacia do Rio das Almas (GO).

Na bacia do Rio Maranhão a agricultura tem máximo de ocupação na unidade de Chapadas e Remanescentes, Rampas de Colúvio I e Depressão Interplanáltica; o cerrado tem máximo de ocupação na unidade de Frentes de Recuo Erosivo e Serras; a pastagem tem máximo de área ocupada no Planalto Retocado (figura 22).

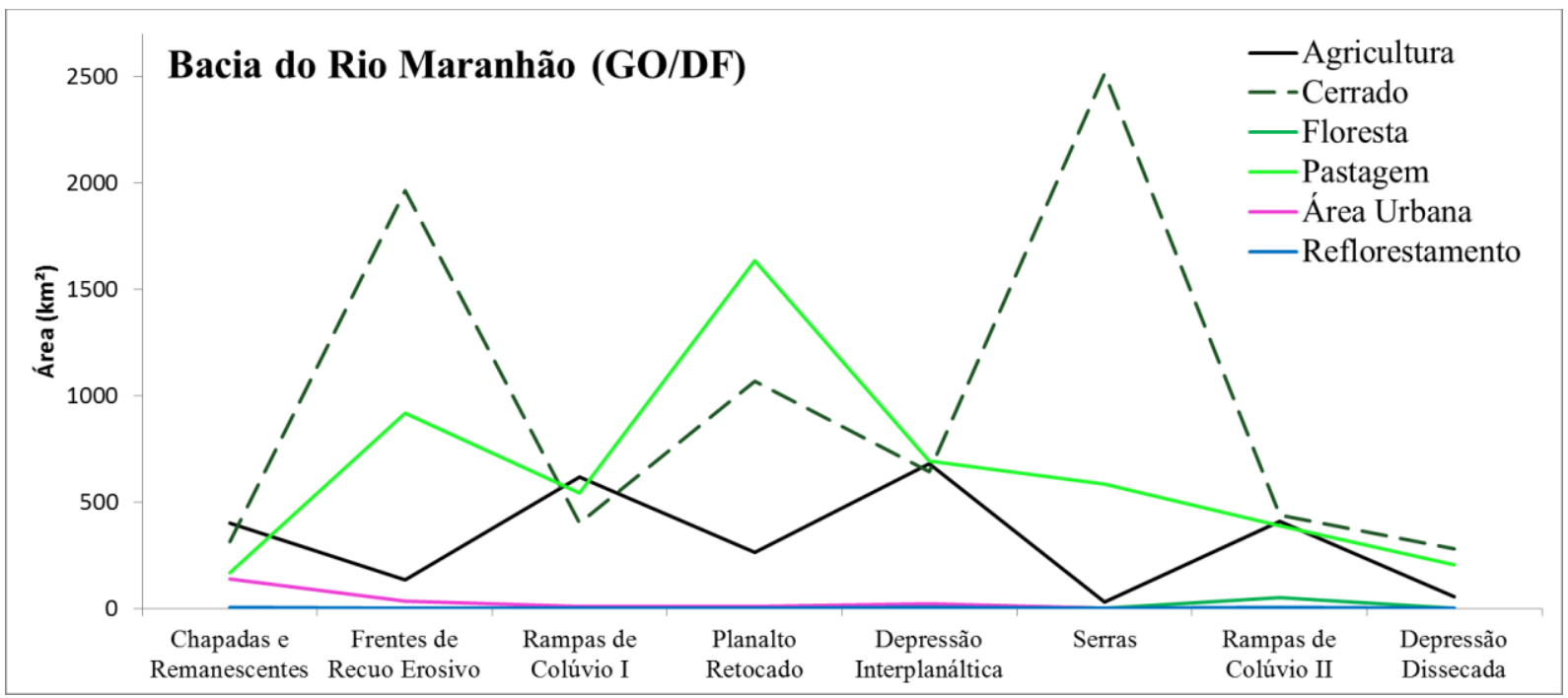

Figura 22. Uso e Cobertura da terra nas unidades geomorfológicas da bacia do Rio Maranhão (GO/DF).

Ambas as bacias hidrográficas constituem-se das mesmas unidades geomorfológicas, contudo, a área ocupada pelas unidades nas bacias é diferente, em que na bacia do Rio das Almas (GO) as unidades de Chapadas e Remanescentes e Rampas de Colúvio I possuem as menores áreas em relação as demais unidades, o que não ocorre na Bacia do Rio Maranhão. Por isso, a análise da assinatura do uso para estas unidades na bacia do Rio das Almas mostrase inexpressiva diante das demais. 
O perfil topográfico auxilia na observação da disposição das unidades geomorfológicas na bacia do Rio das Almas (GO) e na bacia do Rio Maranhão (GO/DF) (figura 23).
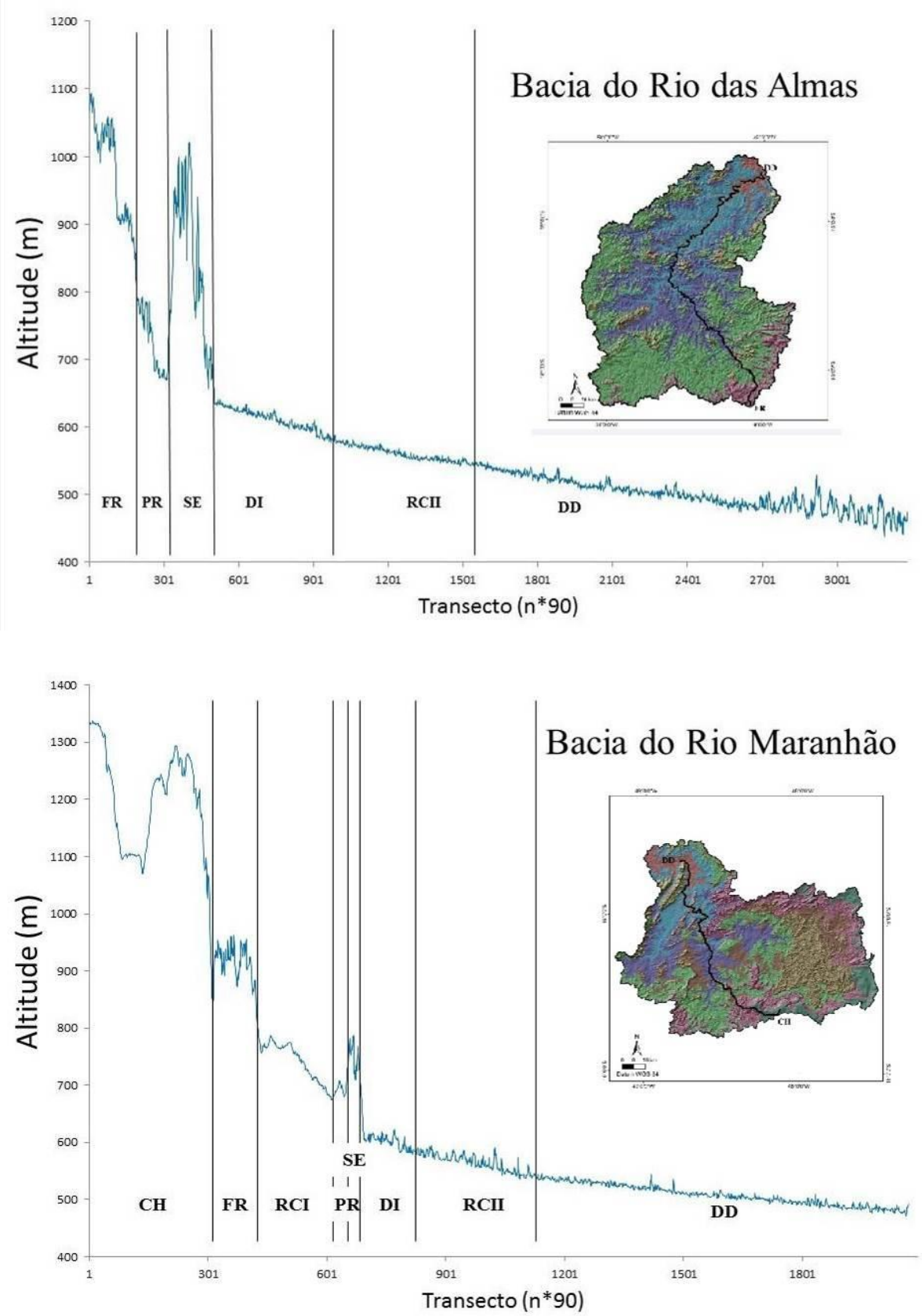

Figura 23. Perfil topográfico das bacias do Rio das Almas e Rio Maranhão e a distribuição das unidades geomorfológicas. Transecto Rio das Almas: FR - Frentes de Recuo Erosivo; PR - Planalto Retocado; SE Serras; DI - Depressão Interplanáltica; RCII - Rampas de Colúvio II; DD - Depressão Dissecada. Transecto Rio Maranhão: CH - Chapadas e Remanescentes; FR - Frentes de Recuo Erosivo; RCI - Rampas de Colúvio I; PR Planalto Retocado; SE - Serras; DI - Depressão Interplanáltica; RCII - Rampas de Colúvio II; DD - Depressão Dissecada.

Segundo Goes (2011) as áreas urbanizadas, quando planejadas ou ordenadas, ocupam geralmente os topos aplainados, as Rampas de Colúvio e os terraços, a pastagem 
geralmente ocupa áreas mais afastadas do meio urbano, como encostas, mas podem ocupar superfícies aplainadas, terraços e interflúvios, e as áreas de vegetação conservada estão associadas as encostas, interflúvios, calhas de vale, terraços, escarpas. Analisando o uso e cobertura da terra nas unidades é possível quantificar as áreas que ainda podem ser ocupadas por usos preferenciais. O sistema geomorfológico é aberto com dinâmica contínua de troca de massa e energia (Latrubesse, 2005), por isso a avaliação pontual da distribuição do uso e cobertura da terra nas unidades geomorfológicas indica o uso potencial de cada uma delas (tabela 6), mas não representa um dado absoluto, em termos de área ocupada pela cobertura vegetal, tendo em vista a própria dinâmica de ocupação da terra.

A determinação dos usos potenciais das unidades geomorfológicas fundamenta-se na distribuição do uso e cobertura da terra sobre as unidades geomorfológicas, que coincide com a classificação de fragilidade ambiental de Ross (1994), na sequencia a determinação da área disponível a ocupação pelo uso preferencial na unidade usa a área coberta por vegetação natural (Cerrado) como área para expansão territorial. O resultado dessa análise indica que a unidade de Chapadas e Remanescentes apresenta potencial uso para a agricultura, que ainda pode ocupar uma área de 30,75\% da unidade; as Rampas de Colúvio I, o Planalto Retocado e a Depressão Interplanáltica tem potencial uso para agricultura e pastagens, e ainda podem ocupar de suas unidades cerca de $25,50 \%, 0,34 \%$ e $19,06 \%$ da área, respectivamente; as Rampas de Colúvio II e a Depressão Dissecada possuem potencial uso para agricultura e pastagem, e ainda podem ocupar $20,93 \%$ e $45,20 \%$ de sua unidade, respectivamente; as unidades de Frentes de Recuo Erosivo e Serras são áreas de fragilidade ambiental, como já descrito anteriormente, pelas suas características de declividade e constituição de solos e por isto sua cobertura vegetal deve apresentar grau de proteção muito alto a alto para redução da degradação dos solos e assim $42,08 \%$ e $28,03 \%$ da área dessas unidades deve ser recuperado, respectivamente (tabela 6)

Tabela 6. Áreas das unidades geomorfológicas, seu potencial de uso e as áreas da unidade que ainda podem ser ocupadas.

\begin{tabular}{l|c|c}
\hline \multicolumn{1}{c|}{ Unidades } & Potencial uso & $\begin{array}{c}\text { Área disponível } \\
\text { ao uso potencial } \\
\mathbf{( \% )}\end{array}$ \\
\hline Chapadas e Remanescentes & Agricultura, Cerrado & 30,75 \\
\hline Frentes de Recuo Erosivo & Floresta, Cerrado & 42,08 \\
Rampas de colúvio I & Agricultura, Pastagens, Cerrado & 25,50 \\
Planalto Retocado & Agricultura, Pastagens, Cerrado & 0,34 \\
Depressão Interplanáltica & Agricultura, Pastagens, Cerrado & 19,06 \\
Serras & Floresta, Cerrado & 28,03 \\
Rampas de colúvio II & Agricultura, Pastagens, Cerrado & 20,93 \\
Depressão Dissecada & Agricultura, Pastagens, Cerrado & 45,20 \\
\hline
\end{tabular}


Apesar de configurarem áreas de fragilidade ambiental as Frentes de Recuo Erosivo e Serras não são acompanham os limites das áreas de conservação da natureza, que possuem características singulares quanto a raridade, biodiversidade e importância ambiental para serem delimitadas. As unidades de conservação da natureza ocupam $2231 \mathrm{~km}^{2}$ da bacia do Rio Maranhão e não ocorrem na bacia do Rio das Almas. As unidades geomorfológicas de Serras têm 20,91\% de sua área inserida nas unidades de conservação, enquanto as Frentes de Recuo Erosivo têm 50,48\% inseridas, o que corresponde apenas a 22,64\% e 10,86\% da área das unidades geomorfológicas, respectivamente. O cerrado é a cobertura com máximo de ocupação nas Serras e nas Frentes de Recuo Erosivo e ocupa 65,81\% da área das unidades de conservação, contudo somente $12,18 \%$ de sua área total está inserida nas unidades de conservação (figura 24). Isso mostra que o máximo de ocorrência do cerrado nas unidades de Serras e Frentes de Recuo Erosivo não está em função dos limites das unidades de conservação, mas em função das condições topográficas apresentadas pelas unidades

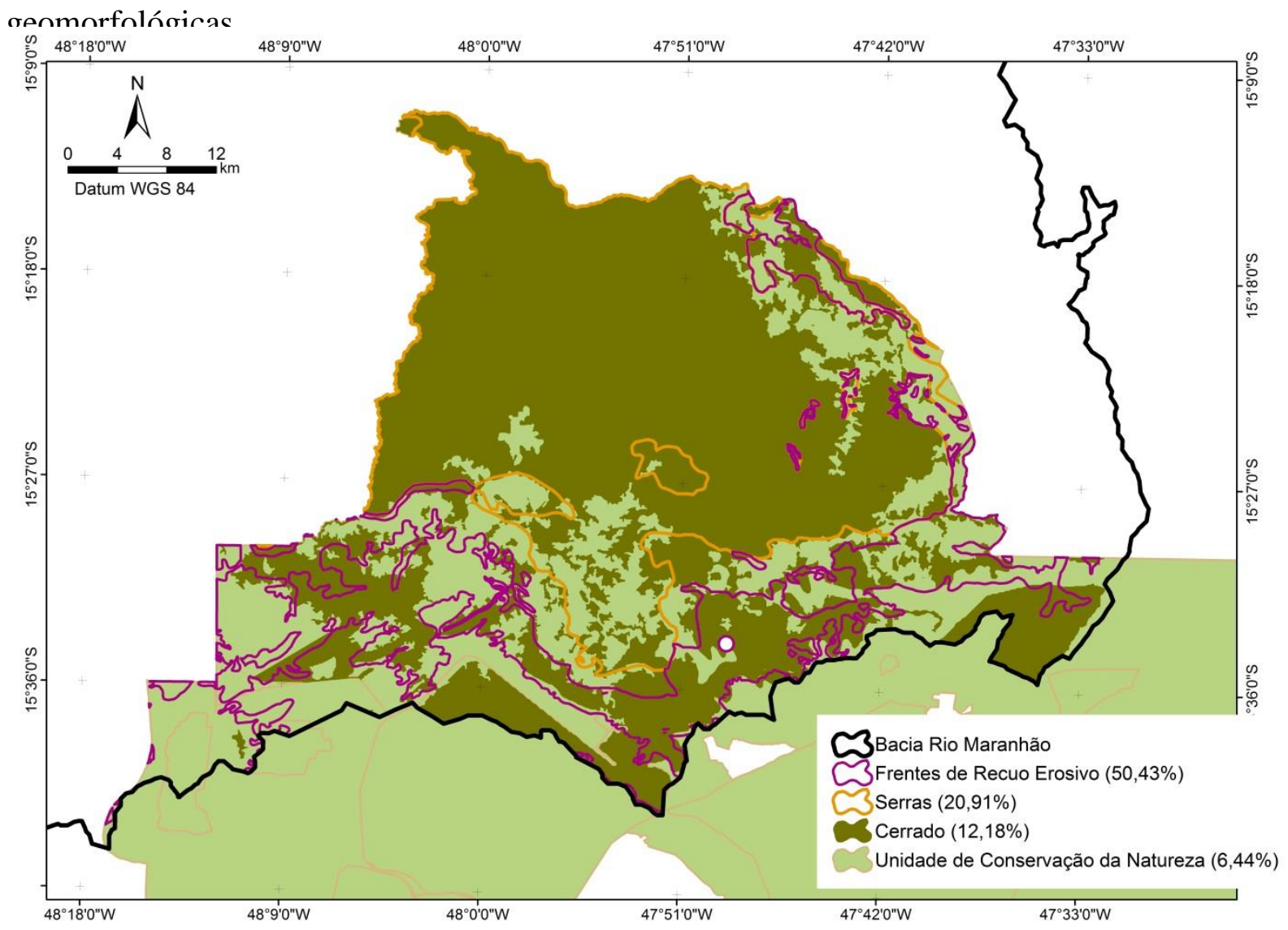

Figura 24. Área de Cerrado inseridas nas Unidades de Conservação da Natureza na Bacia do Rio Maranhão (GO/DF). 


\section{CONCLUSÃO}

Conclui-se que a técnica de mapeamento geomorfológico fundamentado na vetorização em tela a partir da composição colorida das variáveis morfométricas permite a delimitação dos compartimentos do relevo eficientemente, contudo possui o erro vinculado ao usuário, em que a reaplicação do método por diferentes usuários resultará em diferentes limites para as mesmas unidades geomorfológicas. Um mapeamento geomorfológico fundamentado na variação da distribuição da altimetria e da declividade na área de estudo pode ser mais eficiente para a determinação de áreas em intervalos mais definidos dos padrões de relevo.

As unidades geomorfológicas são eficientes à avaliação do uso e cobertura da terra, contribuindo para compreensão da configuração da paisagem, tornando-se um elemento norteador do planejamento e gestão territorial, e indicando áreas com potencial de uso.

O relevo enquanto fator central na escala espaço-temporal dos fatores formadores da paisagem, e enquanto suporte físico para o estabelecimento das atividades humanas permite que as condições topográficas, os solos, a geologia, a hidrografia, a dinâmica da paisagem e as ações antrópicas sejam relacionadas entre si.

A ocupação e o uso da terra, empiricamente, avançam mais rapidamente em áreas de condições topográficas adequadas, assim, o mapeamento geomorfológico vem como uma ferramenta de subsidio ao planejamento e gestão territorial, visando a redução dos impactos ambientais gerados na ocupação de áreas inadequadas à determinada atividade humana, ou até mesmo a escassez e a exaustão de recursos naturais a médio e longo prazo, e oferecendo informações cartográficas atualizadas em escala regional ou municipal.

Conclui-se que as unidades geomorfológicas são representações de compartimentos do relevo capazes de explicar a organização do espaço e a distribuição de uso e cobertura da terra. O fato de refletirem características de constituição e configuração do relevo por meio das variáveis morfométricas permite que as unidades geomorfológicas sejam relacionadas ao uso e cobertura da terra indicando unidades que melhor se adequem a determinado uso, na chamada assinatura do uso.

A assinatura do uso nas unidades geomorfológicas imprime informações do potencial uso para aquela unidade, servindo como uma avaliação de qualificação das unidades aos requisitos para estabelecimento de uso e cobertura da terra e para a conservação ambiental. 
Sugere-se que os trabalhos seguintes acerca desse tema avaliem a dinâmica de uso e cobertura da terra atrelada às unidades geomorfológicas ao invés de analisar um recorte da paisagem em data determinada. 


\section{REFERÊNCIAS BIBLIOGRÁFICAS}

Anacleto, T.C.; Miziara, F. Expansão de fronteiras e ocupação do espaço no cerrado: o caso de Goiás. Geografia, v.31, .n.3, p. 527-538, 2006.

Andrade, D.C.; Reis, T.E.S.; Reis, L.C. Conflito de uso do solo em área de recarga de aquífero Guarani na Bacia do Médio Rio das Cinzas. Revista de Geociências, v. 34, n. 1, p.69$76,2015$.

Andrades Filho, C.O.; Rossetti, D.F. Caracterização morfoestrutural da parte central emersa da bacia Paraíba (PB). Geociências, v. 31, n. 1, p. 11-39, 2012.

Barbosa, O. Guia das Excussões. In: Simpósio Brasileiro de Geologia, 9, São Paulo, Noticiario 3, 1995. p. 3-5.

Beek, K. J. Land evaluation for agricultural developmente: some explorations of land-use systems analysis with particular reference to Latin America. Wageningen: International Institute for Land Reclamation and Improvement, p. 333, (ILR Publication, 23), 1978.

Bispo, P.C.; Valeriano, M. M.; Kuplich, T. M. Variáveis geomorfométricas locais e sua relação com a vegetação da região do interfulúvio Madeira - Purus (AM-RO). Acta Amazônica, v.39, p. 81-90, 2009.

Bispo,P.C.; Valeriano, M. M.; Kuplich, T. M. Relação da vegetação de caatinga com condição geomorfométrica local. Revista Brasileira de Engenharia Agrícola e Ambiental, v. 14,p. 523-530, 2010.

Campos Neto, M. Contribuition à l'estude des Brasilides. Litoestratigraphie et structure des Groupes Canastra, Paranoá e Bambuí dans l'ouest-nord-ouest de l'Etat de Minas Gerais, Brésil. 1979. 155f. Tese (Doutorado - Universidade de Paris).

Campos, J.E.G.; Dadernne, M. A.; Freitas Silva, F. H.; Martins Ferreira, M. A. C. Geologia do Grupo Paranóa na porção externa da Faixa Brasília. Brazil Journal Geology, v. 43, n. 3, p. 461-476, 2013.

Carvalho, T.M.; Ferreira, M.E.; Bayer, M. Análise integrada do uso da terra e geomorfologia do Bioma Cerrado: um estudo de caso para o Goiás. Revista Brasileira de Geografia Física, v. 1, n. 1, p.62-72, 2008.

Castro, K.B.; Martins, E. S.; Gomes, M. P.; Reatto, A.; Lopes, C. A.; Passo, D. P.; Lima, L. A. S.; Cardoso, W. S.; Carvalho Júnior, O. A.; Gomes, R. A. T. Caracterização Geomorfológica do Município Luís Eduardo Magalhães, Oeste Baiano, escala 1:100.000.Brasília. Embrapa Cerrados, 2010. 32p. (Boletim de Pesquisa e Desenvolvimento, 288)..

Cavalcante, A.A.; Cunha, S.B. Morfodinâmica fluvial em áreas semiáridas: discutindo o Vale do Rio Jaguaribe- CE- Brasil. Revista Brasileira de Cartografia, v.13, n; 1, p. 39-49, 2012.

Costa, H.C.; Marcuzzo, F. F. N.; Ferreira, O. M.; Andrade, L. R. Espacialização e sazonalidade da precipitação pluviométrica do Estado de Goiás e Distrito Federal. Revista Brasileira de Geografia Física, v.1, p. 87-100, 2012.

Couto Júnior, A.F. et al. Séries temporais de NDVI, EVI e NDWI do sensor MODIS para caracterização fenológica algodão. Revista Brasileira de Cartografia, v. 1, p. 199-210. 2013.

Couto Junior, A.F.; Souza, V. V.; Carvalho Júnior, O. A.; Martins, E. S.; Santana, O. A.; Freitas, L. Figueiredo; Gomes, R. A. T. Integração de parâmetros morfométricos e imagem 
aster para a delimitação das fitofisionomias da Serra da Canastra, Parque Nacional da Serra da Canastra, MG. Revista Brasileira de Geomorfogia, v.11, p. 57-68, 2010.

Dardenne, M.A. Os grupos Paranoá e Bambuí na Faixa dobrada Brasília. In: Anais Simpósio sobre o Cráton do São Francisco e suas faixas marginais, Salvador, Brasil. 1981, p. 140-157.

Dardenne, M.A. The Brasilia Fold Belt. TectonicEvolution of South America, v.1, p. 231263, 2000.

Estevam, L. O tempo da transformação - estrutura e dinâmica da formação econômica de Goiás. Goiânia, 1998.

Faria, a. Estratigrafia e sistemas Deposicionais do Grupo Paranoá nas áreas de Cristalina, Distrito Federal e São João da Aliança - Alto Paraíso de Goiás. 1995. 199f. Tese (Doutorado - Instituto de Geociências, Universidade de Brasília).

Ferreira Filho, C.F.; Kamo, S. L.; Fuck, R. A.; Krogh, T. E.; Naldrett, A. J. Zircon and rutile $\mathrm{U} / \mathrm{Pb}$ geochronology of the Niquelândia layered mafic-ultramafic intrusion, Brazil: constraints for the timing of magmatism and high grade metamorphism. Precambrian Reserch, v. 68, n. 3, p. 241-255, 1994.

Florenzano, T.G. Cartografia: Cartografia geomorfológica do Brasil. In:FLORENZANO, T.G. (Org). Geomorfologia: conceitos e tecnologias atuais. São Paulo, 2008. p. 111-118

Florenzano, T.G. Sensoriamento remoto para geomorfologia. In:FLORENZANO, T.G. (Org). Geomorfologia: conceitos e tecnologias atuais. São Paulo, 2008. p.36-58..

Fonseca,M.F; Matias, L.F. Análise do uso da terra e do componente clinográfico por meio de geoprocessamento: o entorno do reservatório de Salto Grande - SP. Boletim de Geografia, v. 32, p. 48-60. 2014.

Gastão, F.G.C.; Maia, L.P. O uso de dados da missão SRTM e sedimentológicos nos estudos de geomorfologia e padrões de drenagem na região dos Lençóis Maranhenses. Revista Brasileira de Cartografia, n. 62, v. 2, p. 14, 2010.

Girão, O. ; Corrêa, A.C.B. A contribuição da geomorfologia para o planejamento da ocupação de novas áreas. Revista de Geografia, v. 21, n. 2, p. 36-58, 2004.

Goes, M.H.B. Geoprocessamento aplicado ao mapeamento e análise geomorfológica das áreas urbanas. In: SILVA, J.X.; ZAIDAN, R.T. Geoprocessamento e Meio Ambiente. Rio de Janeiro, 2011. p. 193-196.

Guerra, A.T.; Guerra, A.J.T. Novo Dicionário Geológico - Geomorfológico. Rio de Janeiro: Bertrand Brasil, 2011.p.648.

Guimarães, E.M. Estudos de proveniência e diagênese com ênfase na caracterização dos filossilicatos dos Grupos Paranoá e Bambuí, na região de Bezerra - Cabeceiras (GO). 1997. 270f. Tese (Doutorado, Universidade de Brasília).

Hermuche, P.M.; Guimarães, R. F.; Carvalho, A. P.; Martins, E. S.; Carvalho Júnior, O. A.; Druck, S.; Santos, N. B. F.; Reatto, A. Morfometria como suporte para elaboração de mapas pedológicos: I. Bacias Hidrográficas Assimétricas. Brasília. Embrapa Cerrados, 2002. 23 p. (Documentos, 68).

Ibanez, D.M.; Miranda, F. P.; Riccomini, C. Geomorphometric pattern recognition of SRTM data aplied to the tectonic interpretation of the Amazonian landscape. ISPRS Journal of Photogrammetry and Remote Sensing, v. 87, p. 192-204, 2014. 
IBGE - Instituto Brasileiro de Geografia e Estatística. Manual Técnico em geociências n. 5: Manual Técnico de Geomorfologia. $2^{\circ}$ Edição, p.182, 2009.

IBGE - Instituto Brasileiro de Pesquisa e Estatistica. Atlas nacional do Brasil, domínios morfoestruturais e morfoclimáticos - compartimentos do relevo. 2010.

IPTUR- Instituto de Pesquisa Turística do Estado do Goiás. In: Goiás em dados 2011. Secretaria de Estado de Gestão e Planejamento. Goiânia: SEGPLAN, 2001. p. 106.

Latrubesse, E.M. Mapa Geomorfológico do Estado do Goiás: Relatório Final. Goiânia, 2005. p.81.

Leite, M. R.; Brito, J.L. Mapeamento morfoestrutural e morfoescultural na região do Cerrado do norte de Minas Gerais. Sociedade e Natureza, n. 1, p. 115-126, 2012.

Lima, J.S.S.; Leite, A.M.P. Mecanização. In: Machado, C.C. (Org). Colheita flrestal. Viçosa:Universidade Federal de Viçosa / Imprensa Universitária, 2002. p.33-54.

Lima, L.A.S.; Martins, E. S.; Reatto, A.; Castro, K. B.; MARTINS, E.S. et al. Ecologia de Paisagem: conceitos e aplicações potenciais no Brasil. Brasília. EMBRAPA CERRADOS, 2004. 33p. (Documentos, 121).

Martins, E.S.; Reatto, A.; Carvalho Júnior, O. A.; Guimarães, E. F. Ecologia De Paisagem: Conceitos E Aplicações Potenciais No Brasil. Brasília. Embrapa Cerrados, 2004. 33p. (Documentos, 121).

Martins, J.S. Fronteira: a degradação do outro nos confins do humano. São Paulo: Hucitec, 1997.

Meneses, P. R. Modelos De Cores Aplicados Às Imagens. In: Meneses, P.R.; Almeida, T.(Org) Introdução Ao Processamento De Imagens De Sensoriamento Remoto. Brasília, 2012. P.121-128.

Merino, E.R.; Assine, M. L.; Pupim, F. N.Estilos Fluviais E Evidências De Mudanças Ambientais Na Planície Do Rio Miranda, Pantanal. Revista Brasileira De Geomorfologia, V. 14(2), P. 127-134, 2013.

Nascimento, M.A.L.S. Geomorfologia do Estado do Goiás.Boletim Goiano de Geografia, v. 12,n. 1, 1991.

Ozdogan, M. The Spatial Distribution Of Crop Types From MODIS Data: Temporal Unmixing Using Independent Component Analysis. Remote Sensing Of Environment, V. 114, P. 1190-1204, 2010.

Passo, D. M.; Martins, E. S.;Gomes, M. P.; Reatto, A.; Castro, K. B. ; Lima, L. A. S.; Gomes, R. A. T. Caracterização geomorfológica do município de Barreiras, Oeste Baiano, escala 1:100.000. Brasília. Embrapa Cerrados, 2010. 31 p. (Boletim de Pesquisa e Desenvolvimento, 294.

Pfafsteller, O. Classificação de Bacias Hidrográficas - Metodologia de Codificação. Rio de Janeiro: DNOS. Rio de Janeiro, 1989.

Pimentel, M.M.: Rodrigues, J. B.; Dallagiustina, M. E. S.; Junges, S.; Matteini, M.; Armstrong, R.The tectonic evolution of the Neoproterozoic Brasília Belt, central Brazil, base on SRHIMP and LA_ICPMS U-Pb sedimentary provenance data: A review. Journal of South American Earth Sciences, v. 31, n. 4, p. 345-357, 2011. 
Pimentel, M.M.; Fuck, R. A.; Jost, H.; Ferreira Filho, C. F.; Araújo, S. M. The Basement Of Brasilia Fold Belt And The Goias Magmatic Arc. Tectonic Evolution Of South America, v.31, p. 195-229, 2000.

Pinheiro, L. C. S. J.; Castro, A. S.; Martins, E. S. Levantamentos das classes de solo existentes nas ecorregiões inseridas no limite do Cerrado Contínuo. In: IX Simpósio Nacional Cerrado- II Simpósio Internacional Savanas Tropicais, Brasília, 2008.

Polizel, S.P.; Rossetti, D.F. Caracterização morfológica do delta do Rio Doce (ES) com base em análise multissensor. Revista Brasileira de Geomorfologia, v. 15(2), p. 311-326, 2014.

Ramalho Filho, A.; Beek, K.J. Sistema de avaliação da aptidão agrícola das terras. $3^{\circ}$ ed. Rev. Rio de Janeiro: EMBRAPA - CNPS, p.65, 1995.

Romão, A.C.B.C.; Souza, M.L.D. Análise do uso e ocupação do solo na bacia do Ribeirão São Tomé, noroeste do Paraná (1985 e 2008). Ra'ega, n. 21, p. 337-364, 2011.

Ross, J.L.S. O registro cartográfico dos fatos geomórficos e a questão da taxonomia do relevo. Revista do Departamento de Geografia FFLCH-USP, n.6,1992.

Ross, J.L.S. Análise empírica da fragilidade dos ambientes naturais antropizados. Revista do Departamento de Geografia e Meio Ambiente,n. 8, p. 63-74, 1994.

Rovedder, A. P. M.; Almeida, C. M.; Araújo, M. M.; Tonetto, T. S.; Scotti, M. S. V. Revista Ciência Rural, v. 44, n. 12, p.2178 - 2185, 2014.

Schobbenhaus, C. O Proterozóico Médio no Brasil com ênfase à região Centro-Oeste: uma revisão. 1993.166f. Tese (Doutorado - Universidade albert-Ludwig, Alemanha).

Schobbenhaus, C. O Proterozóico Médio no Brasil com ênfase à região Centro-Oeste: uma revisão. 1993.166f. Tese (Doutorado - Universidade albert-Ludwig, Alemanha).

SEGPLAN. Goiás em dados 2011. Relatório Técnico.Goiás. 106p.

Sena-Souza, J.P.; Martins, E. S.; Couto Júnior, A. F.; Reatto, A.; Vasconcelos, V.; Gomes, M. P.; Carvalho Júnior, O. A.; Reis, A.M. Mapeamento Geomorfológico da Bacia Hidrográfica do Rio são Bartolomeu, escala 1:100.000. Brasília. Embrapa Cerrados, 2013. 38p. (Boletim de Pesquisa e Desenvolvimento, 314).

Silva, A.C.S. Mato Grosso permanece grande e forte: a economia mato-grossense após a divisão. Goiânia: única, 1982.

Silva, C.E.C. Avaliação dos condicionantes ambientais na perspectiva de expansão da produção de etanol no Brasil. 2010. 83f. Dissertação (Mestrado - Curso de Pós-graduação em Planejamento Energético, Universidade Federal do Rio de Janeiro).

Silva, C.L.; Morales, N.; Crósta, A. P.; Costa, S. S.; Jiménez - Rueda, J. R. Analysis of tectonic - controlled fluvial morphology and sedimentar processes of western Amazon Basin: na approach using satellite images and digital elevation model. Anais da Academia Brasileira de Ciências, v. 79 (4), p. 693-711, 2007.

Sobrinho, T.A. et al. Delimitação automática de bacias hidrográficas utilizando dados SRTM. Revista de Engenharia Agrícola de Jaboticabal, v.30 (1), p. 46-57, 2010.

Sobrinho, T.A.; Oliveira, P. T. S.; Rodrigues, D. B. B.; Ayres, F. M. Delimitação automática de bacias hidrográficas utilizando dados SRTM. Revista de Engenharia Agrícola de Jaboticabal, v.30 (1), p. 46-57, 2010. 
Souza, V. V.; Carvalho Júnior, O. A. Compartimentação geomorfológica e suas relações com solos na bacia do Alto Rio Preto, GO. Brasília. EMBRAPA CERRADOS, 2009. 24p. (Boletim de Pesquisa e Desenvolvimento, 255).

Trentin, R.; Robaina, L. E. S.; Sccoti, A. A. V. Mapeamento geomorfológico do município de Manoel Viana - Oeste do Rio Grande do Sul - Brasil. Revista de Geociências, v. 32 (2), p. 333-345. 2013

Uhlein, A.; Fonseca, M. A.; Seer, H. J.; Dardenne, M. A.Tectônica da Faixa de Dobramentos Brasília - Setores Setentrional e Meridional. Gonomos, v. 20, n. 2, p. 1-14, 2012.

Vale, C.C. Teoria geral dos sistemas: histórico e correlações com a geografia e com o estudo da paisagem. Revista Entre - Lugar, v.6, p.85-108, 2012.

Valeriano, M.M. Dados Topográficos: extração automática de variáveis morfométricas. In:FLORENZANO, T.G. (Org). Geomorfologia: conceitos e tecnologias atuais. São Paulo, 2008. p. 85- 91.

Zaloti Junior, O.D.; Freitas, C.C.; Sant'Anna, S.J.S.; Andrade, R.A.M. Avaliação do Modelo Digital do Terreno estraído de dados SRTM - uma abordagem baseada na declividade, aspecto e uso/cobertura do solo. In: Anais XIII Simpósio Brasileiro de Sensoriamento Remoto, Florianópolis, p.5043-5050, 2007. 
ANEXO A - Pontos de controle de campo

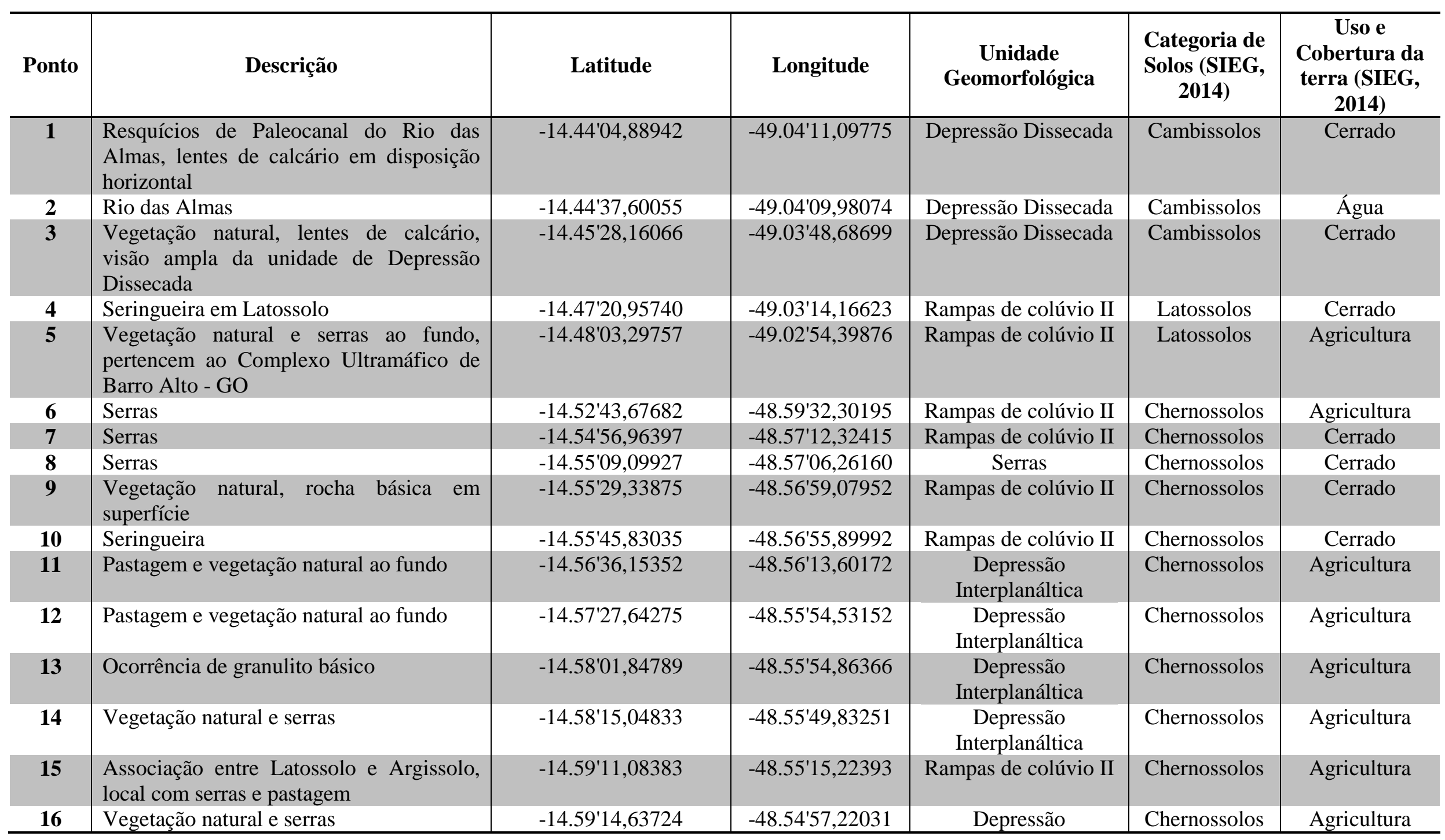




\begin{tabular}{|c|c|c|c|c|c|c|}
\hline & & & & Interplanáltica & & \\
\hline 17 & Vegetação natural e Latossolo & $-14.59 ' 19,67881$ & $-48.54 ' 35,63065$ & $\begin{array}{c}\text { Depressão } \\
\text { Interplanáltica }\end{array}$ & Chernossolos & Agricultura \\
\hline 18 & $\begin{array}{l}\text { Agricultura, vegetação natural nas serras e } \\
\text { solo exposto }\end{array}$ & $-14.59^{\prime} 26,32661$ & $-48.54 ' 30,93994$ & $\begin{array}{l}\text { Depressão } \\
\text { Interplanáltica }\end{array}$ & Chernossolos & Agricultura \\
\hline 19 & Vegetação natural e pastagem & $-14.59^{\prime} 46,90382$ & $-48.54 ' 22,79156$ & $\begin{array}{c}\text { Depressão } \\
\text { Interplanáltica }\end{array}$ & Chernossolos & Agricultura \\
\hline 20 & $\begin{array}{l}\text { Vegetação natural, pastagem e serra, local } \\
\text { caracterizado como Pelito Carbonatada }\end{array}$ & $-15.00 ' 55,15642$ & $-48.53 ' 57,65720$ & Rampas de colúvio II & Chernossolos & Agricultura \\
\hline 21 & Vegetação Natural e cana-de-açúcar & $-15.01^{\prime} 55,91305$ & $-48.53 ' 53,26856$ & $\begin{array}{c}\text { Depressão } \\
\text { Interplanáltica }\end{array}$ & Chernossolos & Agricultura \\
\hline 22 & Cana-de-açúcar e seringueiras & $-15.03^{\prime} 25,08570$ & $-48.54^{\prime} 09,93343$ & Rampas de colúvio II & Chernossolos & Agricultura \\
\hline 23 & Cana-de-açúcar e Cerrado & $-15.07^{\prime} 04,83850$ & $-48.55^{\prime} 43,88589$ & Rampas de colúvio II & Chernossolos & Agricultura \\
\hline 24 & Pastagem e vegetação natural ao fundo & $-15.05^{\prime} 09,25658$ & $-48.51 ' 32,02706$ & Rampas de colúvio II & Latossolos & Pastagem \\
\hline 25 & $\begin{array}{l}\text { Sede e maquinário agrícola, serras ao } \\
\text { fundo }\end{array}$ & $-15.05^{\prime} 54,51203$ & $-48.51^{\prime} 08,27028$ & Rampas de colúvio II & Latossolos & Agricultura \\
\hline 26 & Cultivo de sorgo & $-15.06^{\prime} 06,40849$ & $-48.50 ' 59,69740$ & Rampas de colúvio II & Latossolos & Agricultura \\
\hline 27 & $\begin{array}{l}\text { Cultivo de sorgo e cana-de-açúcar e } \\
\text { vegetação natural }\end{array}$ & $-15.06 ' 16.22527$ & $-48.50 ' 5255616$ & Rampas de colúvio II & Latossolos & Agricultura \\
\hline 28 & $\begin{array}{l}\text { Maquinário agrícola, cana-de-açúcar e } \\
\text { vegetação natural }\end{array}$ & $-15.07 ' 27,76618$ & $-48.50 ' 10,75906$ & Rampas de colúvio II & Cambissolos & Agricultura \\
\hline 29 & Afloramento rochoso de calcário & $-15.09^{\prime} 41,34594$ & $-48.48^{\prime} 00,74496$ & $\begin{array}{c}\text { Depressão } \\
\text { Interplanáltica }\end{array}$ & Cambissolos & Cerrado \\
\hline 30 & Cambissolo & $-15.10^{\prime} 21,62018$ & $-48.47^{\prime} 43,40299$ & $\begin{array}{c}\text { Depressão } \\
\text { Interplanáltica }\end{array}$ & Cambissolos & Cerrado \\
\hline 31 & Pastagem degradada em regeneração & $-15.10^{\prime} 56,16733$ & $-48.47^{\prime} 09,80845$ & $\begin{array}{l}\text { Depressão } \\
\text { Interplanáltica }\end{array}$ & Cambissolos & Agricultura \\
\hline 32 & $\begin{array}{l}\text { Cana-de-açúcar, seringueiras e vegetação } \\
\text { natural }\end{array}$ & $-15.11 ' 39,39996$ & $-48.46^{\prime} 08,42086$ & $\begin{array}{l}\text { Depressão } \\
\text { Interplanáltica }\end{array}$ & Cambissolos & Agricultura \\
\hline 33 & $\begin{array}{l}\text { Área de agricultura com uma ilha de } \\
\text { vegetação natural }\end{array}$ & $-15.12^{\prime} 08,82585$ & $-48.45^{\prime} 05,75991$ & Rampas de colúvio I & Cambissolos & Agricultura \\
\hline 34 & Sede, cana-de-açúcar e vegetação natural & $-15.12^{\prime} 16,72755$ & $-48.43 ' 57,74325$ & Rampas de colúvio I & Cambissolos & Agricultura \\
\hline 35 & Cultivo de eucalipto & $-15.12^{\prime} 18,52447$ & $-48.43^{\prime} 44,31297$ & Rampas de colúvio I & Cambissolos & Agricultura \\
\hline 36 & $\begin{array}{l}\text { Cultivo de milheto e presença de } \\
\text { vegetação natural }\end{array}$ & $-15.12^{\prime} 24,07288$ & $-48.42 ' 55,50445$ & Rampas de colúvio I & Cambissolos & Agricultura \\
\hline
\end{tabular}




\begin{tabular}{|c|c|c|c|c|c|c|}
\hline 37 & Pastagem e vegetação natural & $-15.13^{\prime} 05,40949$ & $-48.37^{\prime} 12,56000$ & $\begin{array}{c}\text { Depressão } \\
\text { Interplanáltica }\end{array}$ & Cambissolos & Pastagem \\
\hline 38 & Cultivo agrícola & $-15.13^{\prime} 03,96172$ & $-48.37^{\prime} 00,66250$ & $\begin{array}{l}\text { Depressão } \\
\text { Interplanáltica }\end{array}$ & Cambissolos & Pastagem \\
\hline 39 & $\begin{array}{l}\text { Visão da unidade de Depressão } \\
\text { Interplanáltica }\end{array}$ & $-15.12^{\prime} 56,74027$ & $-48.35^{\prime} 59,06329$ & $\begin{array}{l}\text { Depressão } \\
\text { Interplanáltica }\end{array}$ & Cambissolos & Pastagem \\
\hline 40 & Saprólito de rochas pelíticas - Rio Verde & $-15.12^{\prime} 53,36517$ & $-48.35^{\prime} 06,77666$ & Rampas de colúvio II & Latossolos & Pastagem \\
\hline 41 & Saprólito de rochas pelíticas - Rio Verde & $-15.12^{\prime} 53,36786$ & $-48.34 ' 51,88075$ & Rampas de colúvio II & Latossolos & Pastagem \\
\hline 42 & $\begin{array}{l}\text { Rocha de folheação suave, quase } \\
\text { horizontal }\end{array}$ & $-15.12^{\prime} 46,23296$ & $-48.34^{\prime} 28,46476$ & $\begin{array}{l}\text { Depressão } \\
\text { Interplanáltica }\end{array}$ & Latossolos & Pastagem \\
\hline 43 & Agricultura e vegetação natural & $-15.12^{\prime} 37,02690$ & $-48.33 ' 55,16857$ & $\begin{array}{l}\text { Depressão } \\
\text { Interplanáltica }\end{array}$ & Latossolos & Pastagem \\
\hline 44 & $\begin{array}{l}\text { Solo exposto, vegetação natural ao fundo } \\
\text { e pastagem degradado em regeneração }\end{array}$ & $-15.12^{\prime} 50,07403$ & $-48.33^{\prime} 33,16045$ & $\begin{array}{l}\text { Depressão } \\
\text { Interplanáltica }\end{array}$ & Latossolos & Pastagem \\
\hline 45 & Saprólito de filito recém intemperizado & $-15.12^{\prime} 57,08321$ & $-48.30 ' 28,35179$ & Planalto Retocado & Latossolos & Cerrado \\
\hline 46 & Agricultura & $-15.12^{\prime} 46,50807$ & $-48.29 ' 38,21903$ & Planalto Retocado & Latossolos & Cerrado \\
\hline 47 & Vegetação natural & $-15.12^{\prime} 36,01741$ & $-48,28 ' 22,37695$ & Planalto Retocado & Neossolos & Cerrado \\
\hline 48 & Vegetação natural & $-15.11 ' 58,77407$ & $-48.27^{\prime} 02,85758$ & Planalto Retocado & Neossolos & Pastagem \\
\hline 49 & Saprólito e vegetação natural & $-15.11^{\prime} 44,52286$ & $-48.266^{\prime} 32,90494$ & Planalto Retocado & Neossolos & Cerrado \\
\hline 50 & Visão da unidade de Planalto Retocado & $-15.10^{\prime} 44,31206$ & $-48.25^{\prime} 15,60434$ & Planalto Retocado & Latossolos & Pastagem \\
\hline 51 & Visão da unidade de Rampas de colúvio II & $-15.10^{\prime} 33,00561$ & $-48.24^{\prime} 19,67150$ & Rampas de colúvio I & Latossolos & Agricultura \\
\hline 52 & $\begin{array}{l}\text { Ambiente de mata seca, presença de } \\
\text { calcário }\end{array}$ & $-15.10^{\prime} 29,48014$ & $-48.244^{\prime} 02,05875$ & Rampas de colúvio I & Latossolos & Agricultura \\
\hline 53 & Pastagem e vegetação natural & $-15.10^{\prime} 23,33360$ & $-48.23 ' 21,63431$ & Rampas de colúvio I & Latossolos & Agricultura \\
\hline 54 & $\begin{array}{l}\text { Pastagem em área agrícola com vegetação } \\
\text { natural }\end{array}$ & $-15.10^{\prime} 26,38868$ & $-48.22^{\prime} 19,95605$ & Rampas de colúvio I & Latossolos & Agricultura \\
\hline 55 & Vegetação natural e pastagem & $-15.09^{\prime} 19,31411$ & $-48.19 ' 30,56368$ & $\begin{array}{c}\text { Depressão } \\
\text { Interplanáltica }\end{array}$ & Cambissolos & Agricultura \\
\hline 56 & Mata seca e afloramento de calcário & $-15.09^{\prime} 43,33184$ & $-48.18 ' 24,52089$ & $\begin{array}{l}\text { Depressão } \\
\text { Interplanáltica }\end{array}$ & Cambissolos & Pastagem \\
\hline 57 & Cidade de Padre Bernardo - Goías & $-15.09^{\prime} 49,17342$ & $-48.17^{\prime} 47,24989$ & $\begin{array}{c}\text { Depressão } \\
\text { Interplanáltica }\end{array}$ & Cambissolos & Pastagem \\
\hline 58 & $\begin{array}{l}\text { Porção inserida no Grupo Canastra, área } \\
\text { caracterizada por filitos intemperizados }\end{array}$ & $-15.11^{\prime} 36,76386$ & $-48.17^{\prime} 02,85206$ & Planalto Retocado & Cambissolos & Urbano \\
\hline 59 & Silos de armazenamento de produtos & $-15.14^{\prime} 40,86639$ & $-48.16 ' 14,25652$ & Rampas de colúvio I & Latossolos & Agricultura \\
\hline
\end{tabular}




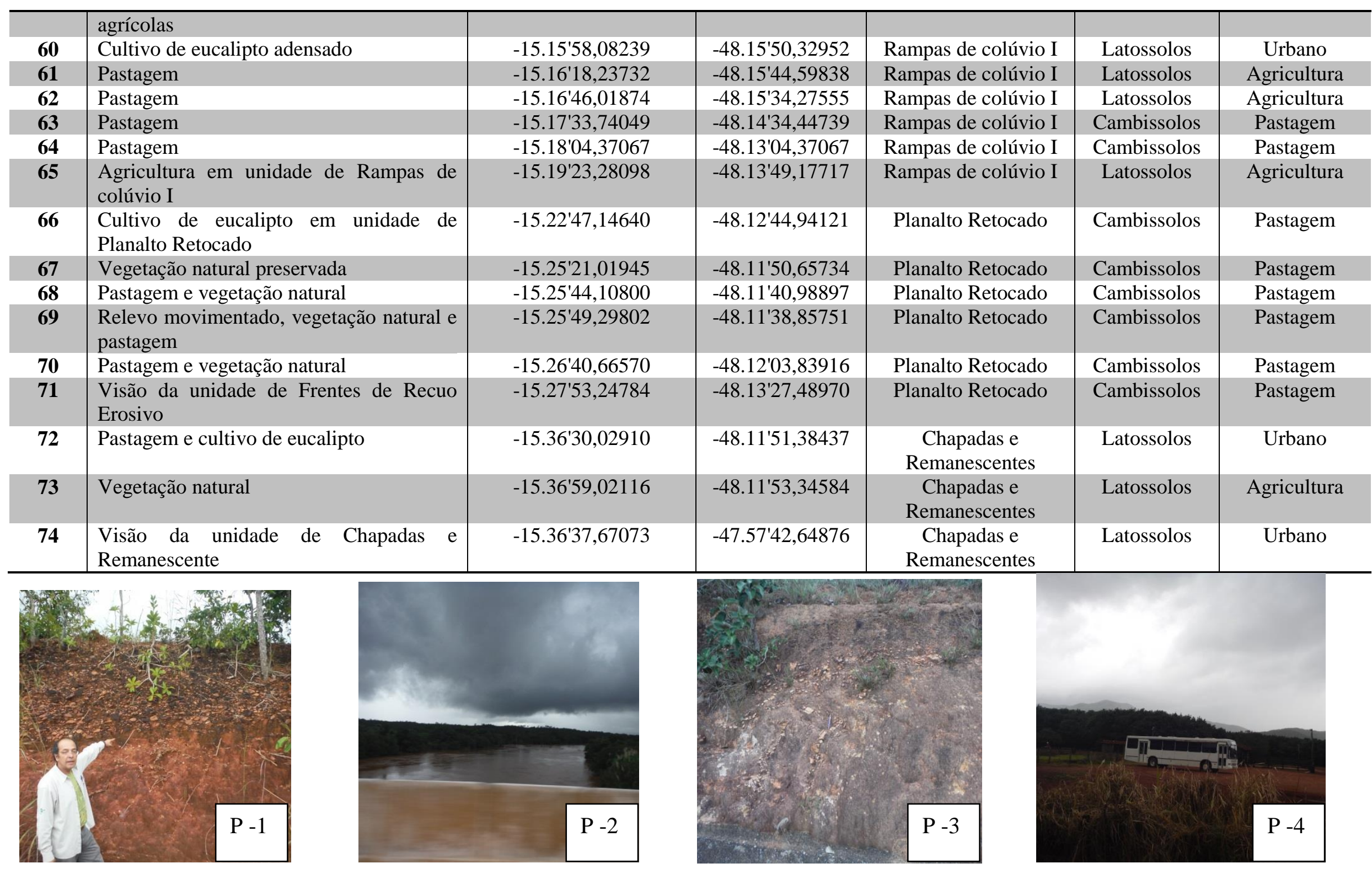



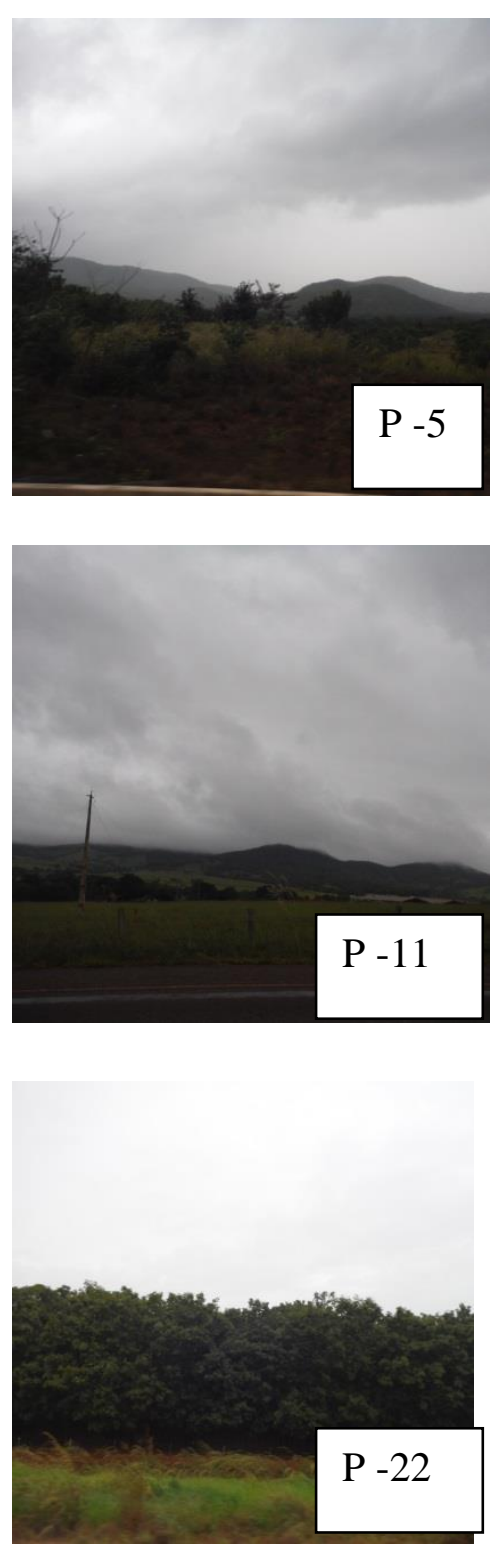
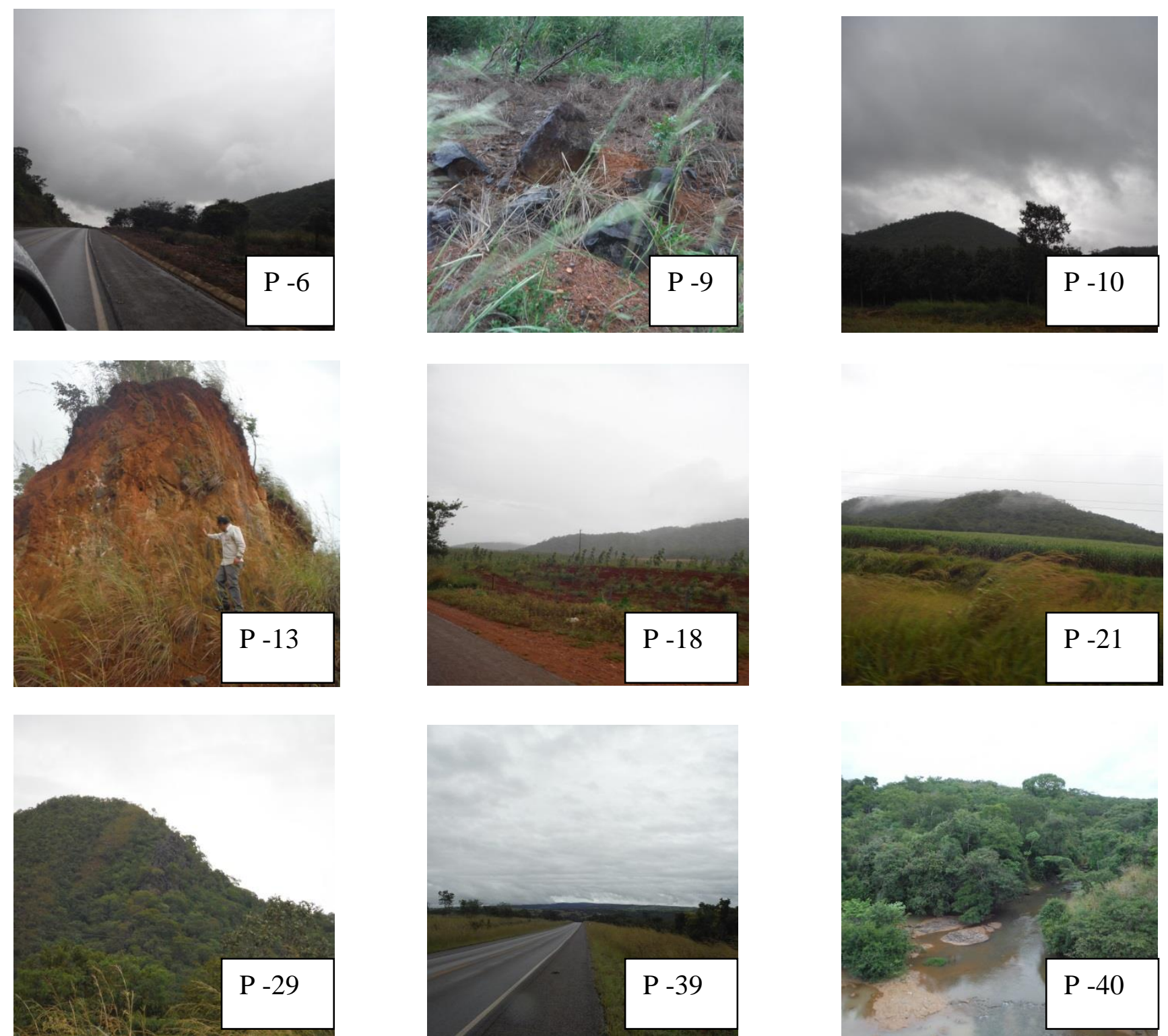

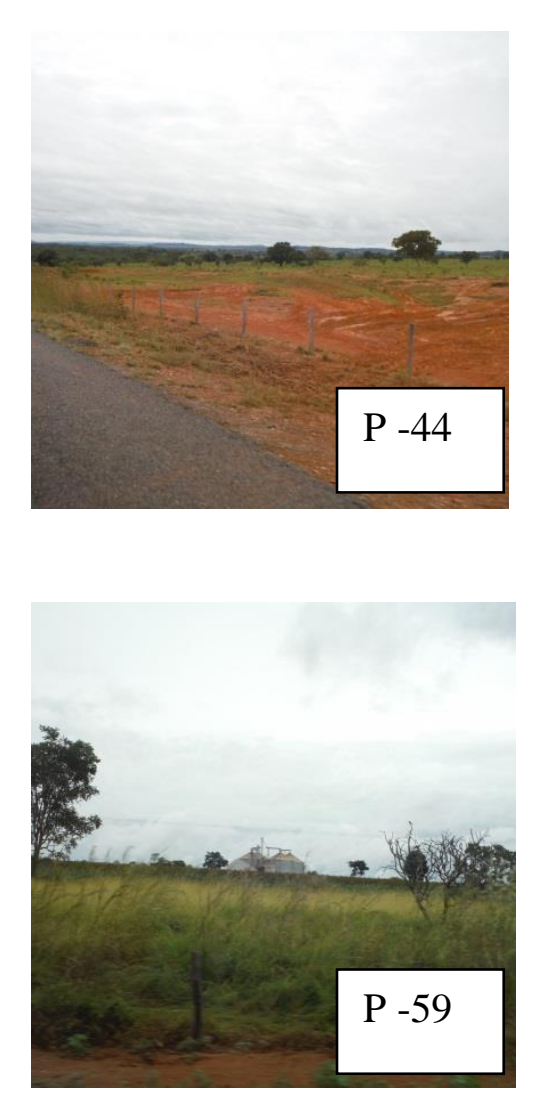
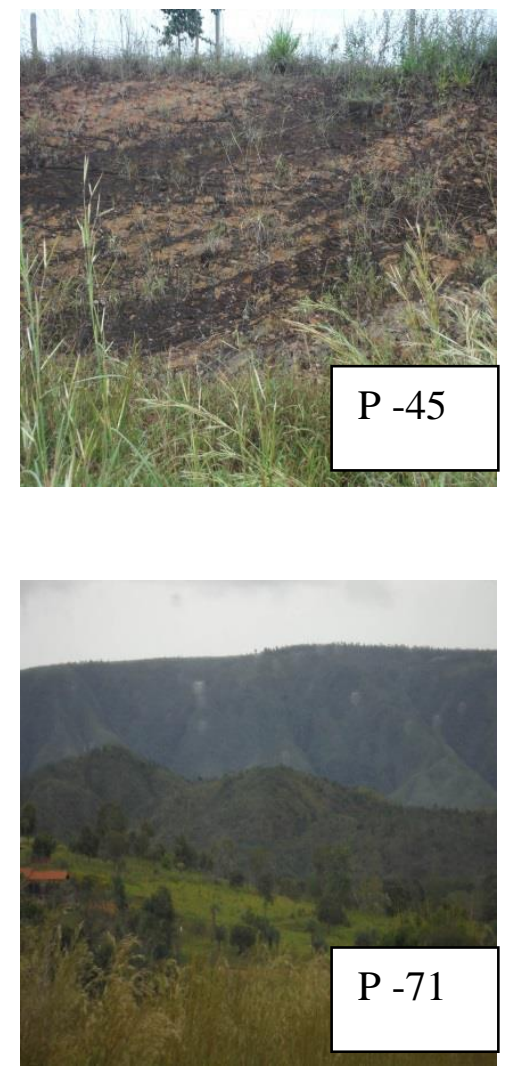
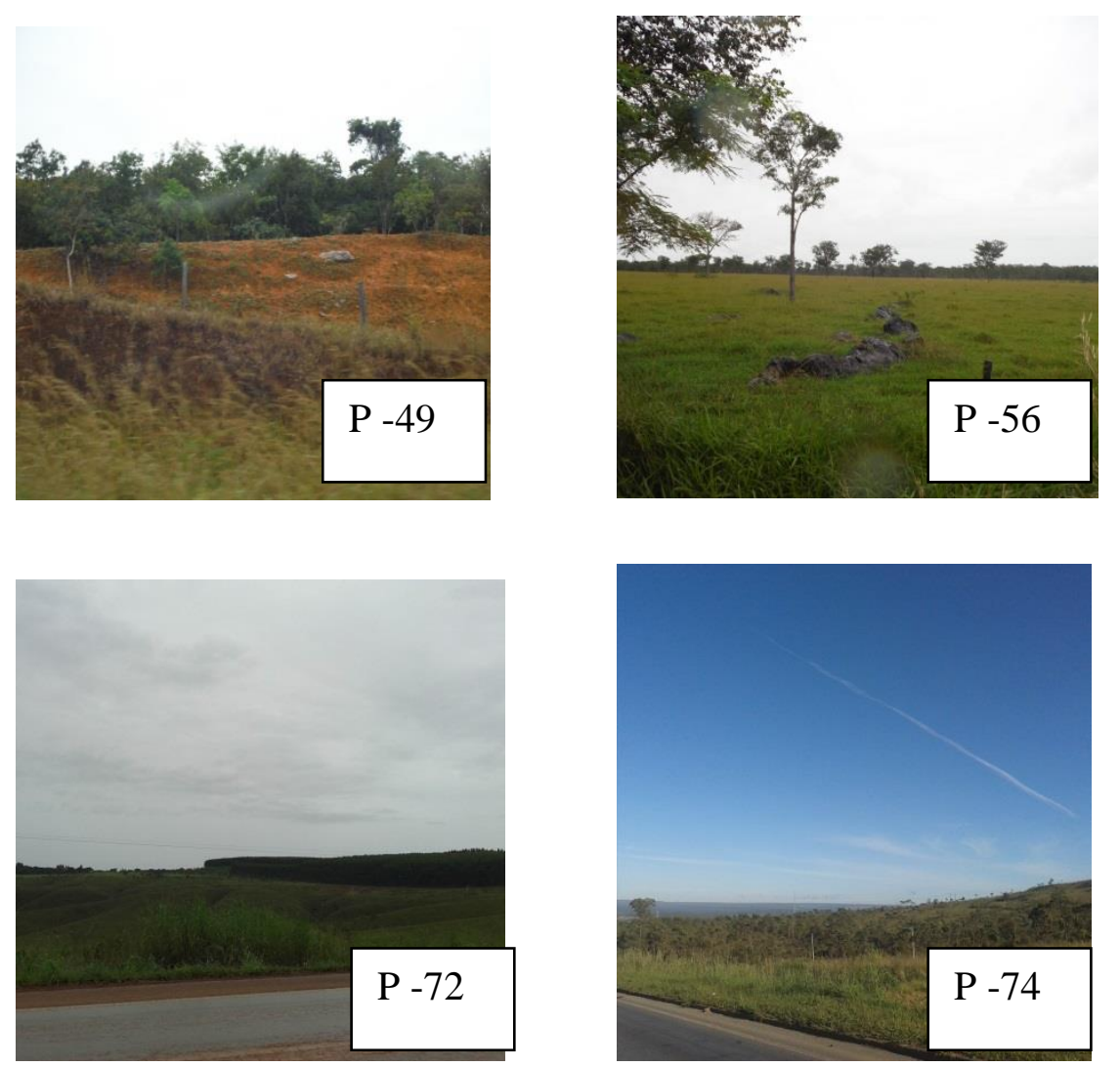